GEOHYDROLOGY OF THE PROPOSED WASTE ISOLATION PILOT PLANT SITE, LOS MEDAÑOS AREA, SOUTHEASTERN NEW MEXICO

By Jerry W. Mercer

U.S. GEOLOGICAL SURVEY

Water-Resources Investigations Report 83-4016

Prepared in cooperation with the

U.S. DEPARTMENT OF ENERGY

Albuquerque, New Mexico 


\author{
UNITED STATES DEPARTMENT OF THE INTERIOR \\ JAMES G. WATT, Secretary \\ GEOLOGICAL SURVEY \\ Dallas L. Peck, Director
}

For additional information write to:

District Chief

U.S. Geological Survey Water Resources Division 505 Marquette NW, Room 720

Al buquerque, New Mexico 87102
For sale by:

Open-File Services Section Branch of Distribution

U.S. Geologica1 Survey, MS 306 Box 25425, Denver Federal Center Denver, Colorado 80225 (303) 234-5888 


\section{CONTENTS}

Abstract - - 2 Pag

Introduction -

Purpose and scope -

Location and areal extent -_-_-_-__-__-_-_-_-_-_-_-_-_ 5

Previous investigations -_-_-_-_-_-_-_-_-_-_-_-_-_-_ 6

Methods of investigation -_-__-_-_-_ 7

Acknowledgments -- 9

Geologic setting - 10

Stratigraphy --_-_- 10

Delaware Mountain Group - 10

Bel1 Canyon Formation --_-_- 11

Guadalupian reef complex-_-_-_- 14

Ochoan Series -

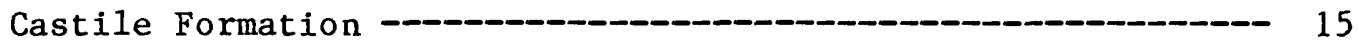

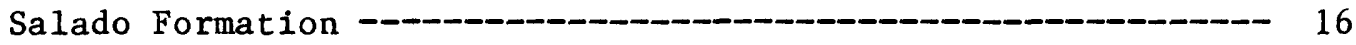

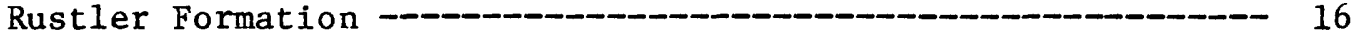

Dewey Lake Red Beds -

Upper Triassic rocks - 19

Santa Rosa Sandstone --_-_-_-_-_-_- 19

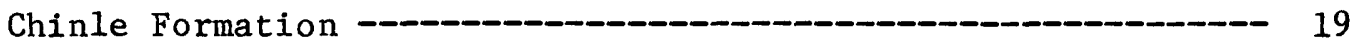

Tertiary and Quaternary rocks -

Ogallala Formation -_- 21

Gatuña Formation -_-_-_-_-_-_-_-_-_-_ 21

Mescalero caliche -_-_-_-_-_-_-_-_-_-_-_-_-_-_-_-_ 21

Alluvium and other surficial deposits -_-_-_-_-_-_-_-_ 21

Ground-water hydrology --_-_- 24

Hydrology of the Delaware Mountain Group - 26

Geohydrologic characteristics -- 26

Ground-water movement --_-_-_-_-_-_-_-_-_-_-_ 31

Hyd rochemistry -_-_-_-_-_-_-_-_-_-_ 32 


\section{CONTENTS - CONCLUDED}

Ground-water hydrology -- concluded

Hydrology of the Guadalupian reef complex 34

Geohydrologic characteristics - 34

Ground-water movement - 38

Hydrochemist ry - 38

Hydrology of the Castile Formation 39

Geohydrologic characteristics - 39

Ground-water movement 41

Hydrology of the Salado Formation- 41

Hydrology of the Rustler Formation- 43

Hydrology of the Rustler-Salado contact residuum - 48

Hydrology of the Culebra Dolomite Member of the

Rustler Formation - 56

Hydrology of the Magenta Dolomite Member of the

Rustler Formation - 63

Hydrology of the Dewey Lake Red Beds 68

Geohydrologic characteristics - 68

Ground-water movement - 70

Hydrology of the Upper Triassic Santa Rosa Sandstone-- 71

Geohydrologic characteristics - 71

Ground-water movement - 71

Hydrology of Tertiary and Quaternary rocks 72

Gatuña Formation - 72

Surficial deposits and alluvium 73

Surface-water hydrology - 75

Summary and conclusions - 76

References - 80 
Figure 1. Map showing location of Los Medaños area and the proposed Waste Isolation Pilot Plant (WIPP) site---- 4

1a. Map showing location of test holes at and near the proposed Waste Isolation Pilot Plant (WIPP) site--- 8

2. Generalized stratigraphic section showing the relationships of the Guadalupian reef complex to those of the Delaware Mountain Group, southeastern New Mexico

3. Diagram showing stratigraphic relationships of the Delaware Mountain Group, Texas and New Mexico

4. Diagram showing the five subdivisions of the Rustler Formation in Nash Draw, Eddy County, New Mexico - - 18

5. Geologic section across the proposed Waste Isolation Pilot Plant (WIPP) site - 20

6. Map showing generalized subsurface extent of Cenozoic fill in southeastern Eddy County, New Mexico

7. Map showing generalized structure contours on top of the Lamar shale (informal unit) of the Bell Canyon Formation (Delaware Mountain Group) in the Delaware Basin, New Mexico and Texas

8. Generalized geologic section across the El Mar Field, Loving County, Texas

9. Map showing potentiometric surface of the hydrologic unit in the upper part of the Bell Canyon Formation (Delaware Mountain Group) at and near the proposed Waste Isolation Pilot Plant (WIPP) site

10. Stratigraphic section showing steepness of the basinal edge of Capitan aquifer, Lea County, New Mexico

11. Map showing potentiometric surface of the Capitan aquifer in the vicinity of the proposed Waste Isolation Pilot Plant (WIPP) site

12. Photographs of core sections from hydrologic units of the Rustler and Salado Formations 


\section{ILLUSTRATIONS - CONCLUDED}

Figure 13. Map showing presence of halite beds and thickness of the Rustler Formation at and near the proposed Waste Isolation Pilot Plant (WIPP) site--_-_-_-_ 46

14. Map showing approximate areal extent of the "brine aquifer" near the proposed Waste Isolation Pilot Plant (WIPP) site -

15. Map showing adjusted potentiometric surface of the Rustler-Salado contact residuum (1982) at and near the proposed Waste Isolation Pilot Plant (WIPP) site -- 52

16. Map showing concentrations of major chemical constituents in water from the Rustler-Salado contact residuum at and near the proposed Waste Isolation Pilot Plant (WIPP) site

17. Map showing adjusted potentiometric surface of the Culebra Dolomite Member of the Rustler Formation (1982) at and near the proposed Waste Isolation Pilot Plant (WIPP) site

18. Photograph showing outcrop of Culebra Dolomite Member of Rustler Formation where removal of underlying halite has caused fracturing

19. Map showing concentrations of major chemica1 constituents in water from the Culebra Dolomite Member of the Rustler Formation at and near the proposed Waste Isolation Pilot Plant (WIPP) site

20. Map showing adjusted potentiometric surface of the Magenta Dolomite Member of the Rustler Formation (1982) at and near the proposed Waste Isolation Pilot Plant (WIPP) site

21. Map showing concentrations of major chemical constituents in water from the Magenta Dolomite Member of the Rustler Formation at and near the proposed Waste Isolation Pilot Plant (WIPP) site 


\section{TABLES}

Page

Table 1. Geologic and hydrologic data from test holes drilled at and near the proposed Waste Isolation Pilot Plant

site

2. Selected chemical and radiochemical analyses of water from test holes at and near the proposed Waste

Isolation Pilot Plant site 9

3. Stratigraphic summary of rock units of Permian

(Guadalupian and Ochoan) and younger age underlying

the proposed Waste Isolation Pilot Plant site and

adjacent areas

4. Summary of drill-stem tests at test holes AEC-7, AEC-8, and ERDA-10, upper part of the Bell Canyon Formation in the vicinity of the proposed Waste Isolation Pilot Plant site

5. Major cations and anions in water from test holes $A E C-7$, AEC-8, and ERDA-10 completed in the upper part of the Bell Canyon Formation in the vicinity of the proposed Waste Isolation Pilot Plant site - 103

6. Measured and density-corrected water levels in selected test holes completed in the Rustler-Salado contact residuum at and near the proposed Waste Isolation Pilot Plant site 104

7. Values of transmissivity and storage coefficient for water-bearing zones in the Rustler Formation penetrated by selected test holes at and near the proposed Waste Isolation Pilot Plant site 105

8. Major cations and anions in water from the Rustler Formation (Magenta Dolomite Member, Culebra Dolomite Member, Rustler-Salado contact residuum) at and near the proposed Waste Isolation Pilot Plant site

9. Measured and density-corrected water levels in selected test holes completed in the Culebra Dolomite Member of the Rustler Formation at and near the proposed Waste Isolation Pilot Plant site

10. Measured and density-corrected water levels in selected test holes completed in the Magenta Dolomite Member of the Rustler Formation at and near the proposed Waste Isolation Pilot Plant site 


\section{CONVERSION FACTORS}

In this report figures for measurements are given in inch-pound units only. The following table contains factors for converting to International System (S.I.) units.

Multiply inch-pound units

foot

foot per mile

foot per day

foot squared per day

gallon per minute

ton (short)

pound per square inch

mile

square mile

inch
By

0.3048

0.1894

0.3048

0.0929

0.06309

0.9072

0.07031

1.609

2.590

25.40
To obtain S.I.units

meter

meter per kilometer

meter per day

meter squared per day

liter per second

megagram

kilogram per square centimeter kilometer

square kilometer

millimeter

Chemical concentrations are given only in metric units--milligrams per liter, micrograms per liter, picocuries per liter, or milliequivalents per liter. Liquid densities are given only in metric units--grams per cubic centimeter.

National Geodetic Vertical Datum of 1929 (NGVD of 1929): A geodetic datum derived from a general adjustment of the first-order level nets of both the United States and Canada, formerly called "Mean Sea Level." NGVD of 1929 is referred to as sea level in this report. 


\title{
GEOHYDROLOGY OF THE PROPOSED WASTE ISOLATION PILOT PLANT SITE, LOS MEDAÑOS AREA, SOUTHEASTERN NEW MEXICO
}

\author{
by Jerry W. Mercer
}

\section{ABSTRACT}

Geohydrologic data have been collected in the Los Medaños area at the U.S. Department of Energy's proposed Waste Isolation Pilot Plant (WIPP) site in southeastern New Mexico since 1975 as part of a study evaluating the feasibility of storing defense-associated nuclear wastes within the bedded salt of the Salado Formation of Permian age. Drilling and hydrologic testing have identified three principal water-bearing zones above the Salado Formation and one below that could potentially transport wastes to the biosphere if the proposed facility were breached. The zones above the Salado are the contact between the Rustler and Salado Formations and the Culebra and Magenta Dolomite Members of the Rustler Formation of Permian age. The zone below the Salado Formation consists of channel sandstones in the Bell Canyon Formation of the Permian Delaware Mountain Group.

Determinations of hydraulic gradients, directions of flow, and hydraulic properties were hindered because of the negligible permeability of the water-bearing zones. Special techniques in drilling, well completion, and hydraulic testing have been developed to determine the hydrologic characteristics of these water-bearing zones.

The Rustler Formation contains the principal water-bearing zones identified at the WIPP site, and thus was the most extensively studied. Calculations from pumping, slug, and pressure-pulse tests indicate that the transmissivities of the units vary laterally within, as well as between, the individual beds. The Culebra Dolomite Member is the most persistent and productive hydrologic unit in the WIPP site area and also has the greatest variability of hydraulic properties. This variability results from the size and number of fractures, which in turn are related to the degree of evaporite dissolution within the Rustler Formation. Transmissivities calculated for the Culebra in Nash Draw immediately west of the WIPP site range from 18 to 1,250 feet squared per day, whereas they range from $1 \times 10^{-3}$ to 140 feet squared per day at the WIPP site. Potentiometric-surface maps (as equivalent 
freshwater heads) indicate flow in the Culebra Dolomite Member of the Rustler Formation at the WIPP site to be southerly, eventually flowing southwestward to Nash Draw. Determination of flow directions, however, may be significantly affected by directional differences in permeability along fractures. The dominant dissolved ions are sodium and chloride, with calcium, magnesium, potassium, and sulfate being other major ions present. Hydrochemistry studies indicate an increase of mineralization of water from west to east along with a decrease in circulation of the flow system. The dissolved-solids concentrations across the WIPP site range from 3,200 to 420,000 milligrams per liter.

The Magenta Dolomite Member is the uppermost hydrologic unit. Water in this unit occurs either in thin silt beds and silty dolomite or in fractures where extensive evaporite dissolution has occurred in the Rustler Formation. Transmissivities calculated for the Magenta in Nash Draw range from 53 to 375 feet squared per day, whereas they range from $4 \times 10^{-3}$ to $1 \times 10^{-1}$ foot squared per day at the WIPP site. Potentiometric-surface maps (as equivalent freshwater heads) indicate flow in the Magenta to be westward toward Nash Draw where the flow direction is then controlled by the evaporite dissolution in the Rustler. The water is brackish to briny. The dominant dissolved ions are sodium and chloride with calcium, magnesium, potassium, and sulfate being other major ions. Dissolved-solids concentrations across the WIPP site range from 5,460 to 270,000 milligrams per liter.

The least productive water-producing zone is at the contact between the Rustler and Salado Formations where brine occurs either in an evaporite residuum or in clays along bedding planes. The residuum is concentrated along Nash Draw and is most extensive between Malaga Bend on the Pecos River, 10 miles southwest of the proposed WIPP site, and Laguna Grande de la Sal, where transmissivities are as large as 8,000 feet squared per day. North of Laguna Grande de $1 \mathrm{a}$ Sal in Nash Draw, the transmissivities range from $2 \mathrm{x}$ $10^{-4}$ to 8 feet squared per day; transmissivities at the WIPP site range from $3 \times 10^{-5}$ to $5 \times 10^{-2}$ foot squared per day. Potentiometric surface maps (as equivalent freshwater heads) indicate flow in the contact zone to the southwest across the WIPP site toward Nash Draw. The dissolved solids in the brines at the Rustler-Salado contact are predominantly sodium chloride with dissolved-solids concentrations ranging from 79,800 to 480,000 milligrams per liter. Large potassium and magnesium ion concentrations in the eastern part of the site may indicate restricted circulation of the brines.

The relative static heads or formation pressures of the hydrologic units in the Rustler decrease with depth; that is, static heads are the highest in the Magenta and the lowest at the contact zone between the Rustler and Salado. In the WIPP site area, the presence of relatively impermeable interbeds of halite and anhydrite probably restricts vertical movement between units. The Rustler Formation probably is recharged in Bear Grass Draw about 20 miles northwest of the WIPP site and in Clayton Basin, which is about 12 miles northwest of the WIPP site. The major discharge occurs at Malaga Bend on the Pecos River. 
Data collected from drill-stem tests in test wells penetrating the Bell Canyon Formation indicate that the brines associated with the unit usually occur in relatively isolated channel sandstones that are permeable (hydraulic conductivities ranging from $7 \times 10^{-3}$ to $5 \times 10^{-2}$ foot per day) but grade vertically and laterally into siltstones and shales with little permeability. Potentiometric-surface maps (as equivalent freshwater heads) show flow in the Bell Canyon Formation to be laterally across the basin to the northeast, but the movement probably is extremely slow. The dissolved ions in the brines of the Be11 Canyon are predominantly sodium and chloride with dissolved-solids concentrations ranging from 180,000 to 270,000 milligrams per liter.

\section{INTRODUCTION}

\section{Purpose and Scope}

The U.S. Geological Survey, at the request of the U.S. Department of Energy, is investigating the geohydrology of the proposed Waste Isolation Pilot Plant (WIPP) site in an area known as Los Medaños, 30 miles east of Carlsbad, New Mexico (fig. 1). Geohydrologic data have been collected from this area by the U.S. Geological Survey intermittently since 1972 and on a continuous basis since 1975 .

The WIPP is a project of the Department of Energy and is proposed as a radioactive-waste storage facility to be placed at a depth of approximately 2,150 feet in the bedded salts of the Permian Salado Formation. The WIPP is planned to demonstrate disposal technology for transuranic wastes. After a period of "pilot" operation in a waste-retrievable mode, it is expected WIPP will be converted into a facility for permanent storage of transuranic wastes (Powers, 1981, p. 119).

The characteristics of the regional geohydrologic systems associated with the WIPP site need to be defined because of the potential for transport of radionuclides to the biosphere by ground water in the event the storage facility is breached. Another equally important aspect of the WIPP study is the determination of the geologic stability of the formation in which the wastes will be placed. Because the formation of concern is easily dissolved halite, the inherent stability of the formation is directly related to the hydrologic regime within and around the formation and needs to be studied in detail.

At the WIPP site, water-bearing zones above and below the salt section could affect stability as well as potentially transport radionuclides. Because some of these water-bearing zones are more likely to be involved than others, the degree of certainty required in the definition of flow paths, velocity of ground water, quality of water, and other characteristics is different for some zones than others. 


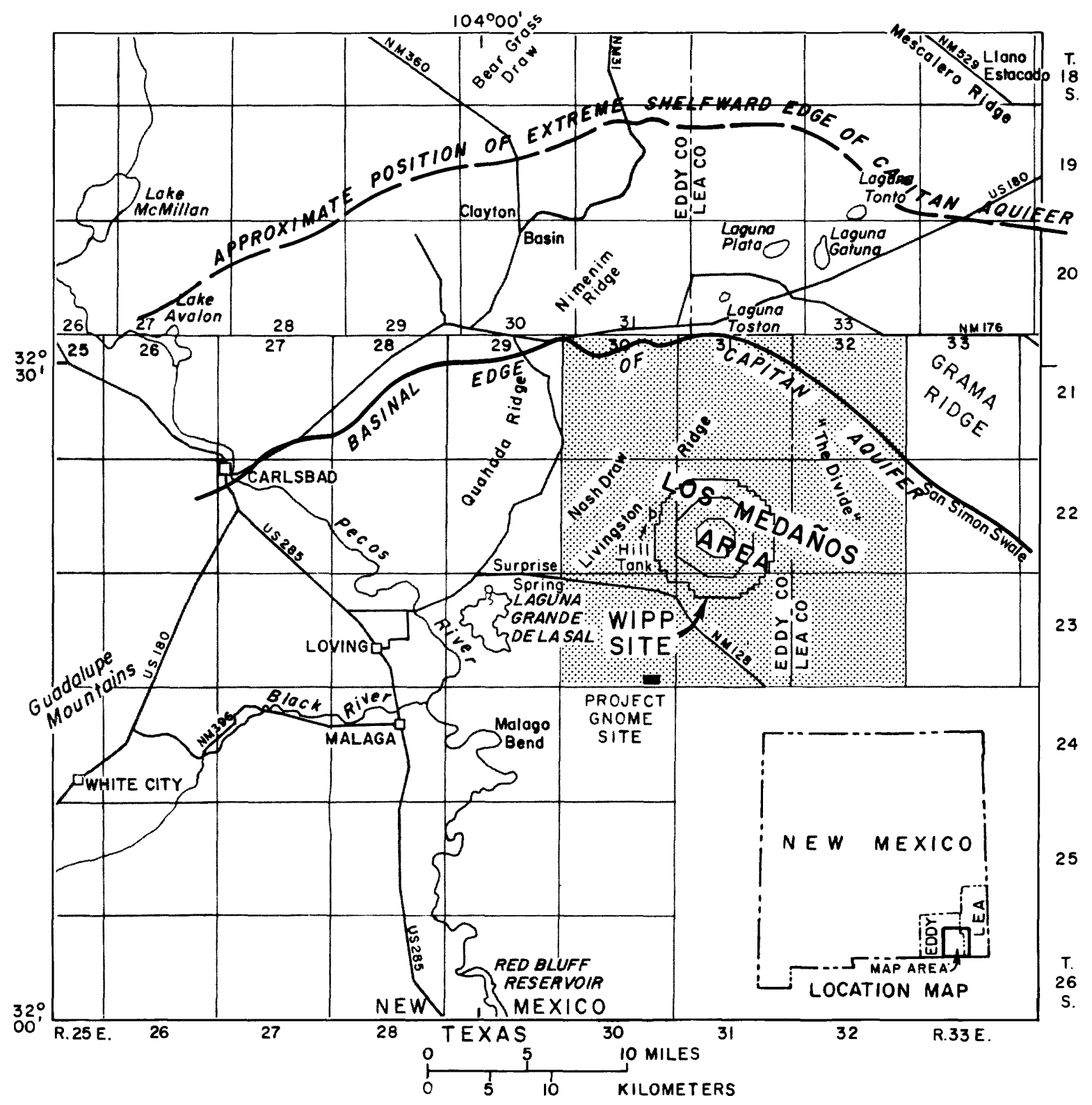

Figure 1.--Location of Los Medaños area and the proposed Waste Isolation Pilot Plant (WIPP) site 
This report discusses the ground-water systems and the interpretation of test results in the water-bearing zones above and below the proposed facility. Hydrologic data used in these analyses were collected during 7 years beginning in 1975 and were from 39 test holes drilled for, or converted to, hydrologic test holes. The study included: the determination of potential ground-water flow boundaries; potentiometric heads; ground-water chemistry; and hydraulic properties obtained through pumping, slug, pressure-pulse, and tracer tests.

The hydrologic investigation is part of a comprehensive study related to site characterization and validation conducted on behalf of the U.S. Department of Energy by Sandia National Laboratories. The hydrologic studies were conducted by the U.S. Geological Survey and were designed to supplement the technical site-characterization program performed by Sandia.

\section{Location and Areal Extent}

The study area of approximately 800 square miles is located within the northern part of the Delaware Basin in eastern Eddy and western Lea Counties, New Mexico and includes all or part of Tps. 21-23 S., Rs. 30-32 E. (fig. 1). The WIPP site is approximately in the center of the study area and covers about 54 square miles, encompassing almost all of T. 22 S., R. 31 E. (fig. 1). It is outlined in figure 1 by a proposed exclusion boundary, or buffer zone, surrounding the area of the proposed facility.

The WIPP site is in an area referred to as Los Medaños. Los Medaños is part of a gently sloping terrain that rises eastward from the Pecos River to the "caprock" of the Llano Estacado. The topographic relief generally is less than 50 feet; the surface area is covered with sand dunes. Vegetation consists of mesquite, scrub oak, and other plants typical of the northern Chihuahuan desert. The average annual precipitation is 11 to 13 inches, while evaporation from surface water exceeds 98 inches per year. The primary land use is cattle grazing. Potash is being mined in the area to the north and west; petroleum exploration and development recently has become quite intensive.

The major topographic features in the area include two depressions called Nash Draw and Clayton Basin. Nash Draw is the larger, being 4 to 6 miles wide and 15 to 18 miles long, extending southward through the western part of the area (fig. 1). These features are believed to have been formed by solution-subsidence and collapse and then extensively modified by erosion. Neither Nash Draw nor Clayton Basin has external surface drainage. 
Los Medaños area is drained by the Pecos River, the only perennial stream in the region. The Pecos drainage system trends southeastward through the western margin of the study area and is at its closest point 10 miles from the WIPP site.

Laguna Grande de la Sal (Great Salt Lake), a large salt lake in the southern end of Nash Draw, contains water most of the time. Numerous small lakes and playas contain water only after intense rains, whereas small permanent tailings ponds, resulting from potash mining, occupy several of the smaller closed depressions.

\section{Previous Investigations}

The Delaware Basin geology in southeastern New Mexico has been studied extensively during the past 40 years, especially since the increase in oil and gas exploration. Prior to the establishment of the WIPP project, however, relatively little study was devoted to the Permian formations (above the Bell Canyon Formation), which include the evaporites of concern. Lang (1937) was one of the first to discuss these rock units and topographic features in the area; however, the most intensive geologic work prior to the WIPP project was done by $\mathrm{C}$. L. Jones and others in connection with the U.S. Geological Survey's study of the potash deposits of the Carlsbad area. Reports were prepared by Jones (1954, 1959, 1972), Jones and Madsen (1959), and Jones, Bowles, and Bell (1960). The other significant geologic studies concentrating on this sequence of rocks were related to the Gnome experiment (an underground nuclear test) and include work by Vine (1963), Cooper (1960, 1961, 1962a, and 1962b), and Gard (1968). Numerous recent geologic papers concerned with the WIPP site investigations have been published and are included as references in this report and in a report published by Sandia National Laboratories (Powers and others, 1978).

The first detailed hydrologic work in the area was conducted by Robinson and Lang (1938) during studies of the occurrence of brine springs in the Malaga area during 1937-38. Additional work was performed in the Malaga Bend area from 1938 to 1941; the results of this work, particularly that of Theis and Sayre (1942), was published in "Reports of the participating agencies, the Pecos River Joint Investigation." Further detail on the Malaga Bend salinity problem was added by Hale (1945a, 1945b, 1961), Hale and Clebsch (1958), Hale, Hughes, and Cox (1954), Cox and Kunkler (1962), Cox and Havens (1965), and more recently, Havens and Wilkins (1980) and Kunkler (1980). The regional occurrence of ground water in the area was discussed by Hendrickson and Jones (1952) and Nicholson and Clebsch (1961). Hiss (1976) made an extensive contribution to the hydrology of the Capitan Reef in a dissertation prepared while working with the U.S. Geological Survey. Others that made contributions to an understanding of the Capitan Reef include Bjorklund and Motts (1959), Halpenny and Greene (1966), and Motts (1968). Associated with 
the Project Gnome investigations, contributions by Cooper (1961, 1962a, 1962b), Cooper and others (1962), and Cooper and Glanzman (1971) have greatly added to an understanding of the geohydrology of the Rustler Formation.

Recent investigations related to hydrologic characteristics of the WIPP site began with a review of the geology and hydrology of the Carlsbad potash area (Brokaw, Jones, Cooley, and Hays, 1972) and a review of the Los Medanos area (Jones, Cooley, and Bachman, 1973). A review of the regional hydrology of the WIPP site area was presented by Mercer and Orr (1977), while detailed hydrologic studies are included in an interim data report by Mercer and Orr (1979) and in a paper by Mercer and Gonzalez (1981).

The dissolution in the WIPP area is complex and has been considered in studies of the Cenozoic history of the area by Bachman (1973, 1974, 1976, 1980, and 1981). These studies added greatly to an understanding of the hydrologic systems in the area. Additional interpretations of dissolution have been prepared by Lambert (1982) and Anderson (1978, 1981).

\section{Methods of Investigation}

The objective of the hydrologic program was to define the hydrologic characteristics of the flow path of the ground-water system that could potentially transport wastes to the biosphere. Hydrologic information required to define the flow-path characteristics included static heads or reservoir pressures, the magnitude and direction of ground-water flow, and the chemical characteristics of the water that may have an effect on dissolution or on chemical interactions with rocks along the flow path.

The lack of very permeable rocks and the consequent lack of existing wells within the WIPP study area necessitated the development of a comprehensive drilling and testing program. This program included test holes for both site-specific geohydrologic studies and regional studies. Seventy-one test holes were drilled during WIPP studies; of these, 26 were specifically for hydrologic testing ( $H$ series) and 13 of the 45 geologic test holes were later used or converted for hydrologic testing (table l, fig. la). These holes range in depth from 154 to 4,910 feet. Because the water-producing zones had little permeability and consequently would require months of recovery time and testing, special techniques in drilling, well completion, and hydraulic testing were developed to determine the hydrologic characteristics of the water-producing zones (Basler, 1983).

The air-rotary method was used to drill two types of holes specifically designed for hydrologic testing: (1) Holes were drilled, cased, cemented, and then perforated at the selected test zone; and (2) three closely spaced holes were drilled in a complex, each cased down to a specific test interval. 


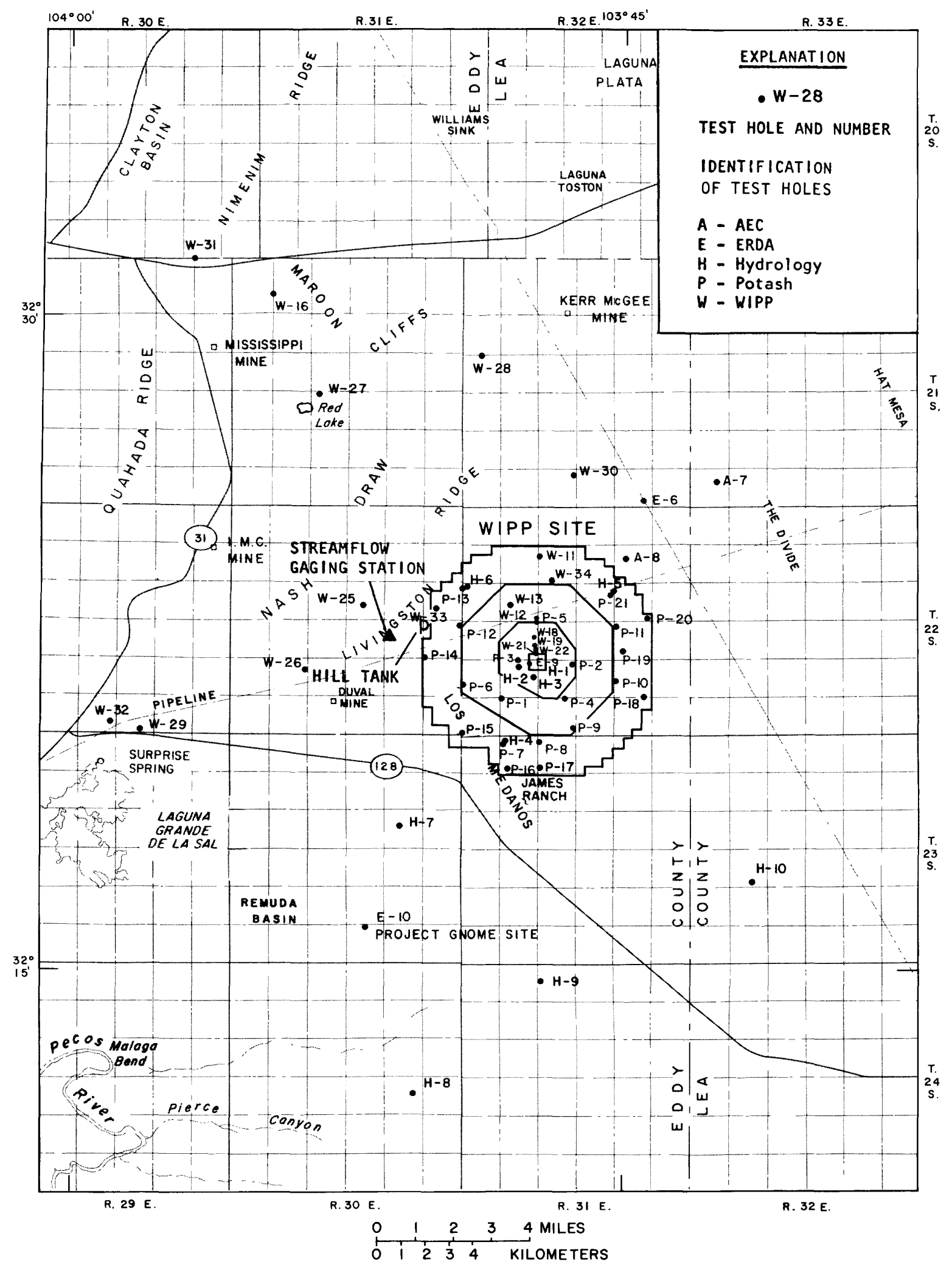

Figure 1a.--Location of test holes at and near the proposed Waste Isolation Pilot Plant (WIPP) site 
Each of these holes in the second type then was completed by coring to total depth through the zone of interest, leaving an open-hole interval for testing. The three-hole complex proved to be the most commonly used and most effective design (Mercer and Gonzalez, 1981, p. 126). The casing-cementing-perforating method continued to be used in the geologic test holes, some of which later were converted to hydrologic holes.

Testing equipment designed for the WIPP geohydrologic studies used hydraulically inflated packers to isolate specific horizons and pressure transducers to measure changes in pressure head. Withdrawal, injection-slug, and pressure-pulse tests were conducted in the zones with little permeability, and standard aquifer tests were conducted in zones with greater permeability. These data were analyzed by methods discussed by Cooper, Bredehoeft and Papadopulos (1967), Lohman (1972), and Bredehoeft and Papadopulos (1980). A detailed discussion of the methods used, including data and data analyses, are not included in this report; however, this information is available in previous reports (Mercer and Orr, 1979; Mercer, Davis, Dennehy, and Goetz, 1981; Mercer and Gonzalez, 1981; Dennehy and Mercer, 1982; and Dennehy, 1982).

During the investigation, water levels were measured periodically in about 40 wells. The geology of the water-bearing units was interpreted by use of formation cuttings, cores, and geophysical logs. In addition, water samples were collected from 52 selected intervals in 40 wells. Complete analyses of these samples are included in the data reports and selected analyses are included in table 2 of this report. Other hydrologic data from previous reports were used extensively in this report.

\section{Acknowledgments}

This investigation was funded by the U.S. Department of Energy, a cooperative effort of the U.S. Geological Survey and Sandia National Laboratories. Field-operations support was directed by Robert Statler of Sandia National Laboratories, and scheduling and direction of support operations were the efforts of W. E. Cunningham, D. L. Bradley, Wayne Laney, and Matthew Wilson of Fenix and Scisson, Inc. Technical reviews and assistance in program development were provided by Wendell Weart, Dennis Powers, Les Hill, and Don Gonzalez of Sandia. Special acknowledgment is made to the U.S. Geological Survey personnel who assisted in the hydrologic studies in the field, primarily C. L. Jones, R. P. Snyder, G. O. Bachman, and R. K. DeWees. James Basler was responsible for most of the data collection and for the design of instrumentation for testing low permeability zones; data analyses and assistance in data collection were handled by Kevin Dennehy and Jane Wells. 


\section{GEOLOGIC SETTING}

Sedimentary rocks of the Delaware Basin that crop out within the WIPP site area range in age from Permian to Quaternary (table 3). The oldest rocks crop out to the west and successively younger rocks to the east. Detailed stratigraphy primarily is based on information obtained from drill holes because the rocks generally are covered by Quaternary caliche and semi-stabilized and active dune sand. Seventy-one holes ranging in depth from 154 feet to 4,910 feet have been drilled for geologic and hydrologic investigations. Rocks penetrated in these test holes mainly consist of Permian sandstones, evaporites, and red beds, but they also include some Triassic sandstone and Tertiary and Quaternary deposits.

The oldest and deepest formations studied are included in the Guadalupian Delaware Mountain Group which forms the basin floor for the Ochoan evaporite sequence. The margins of the basin are delineated by an encircling Guadalupian reef complex consisting of the Capitan Limestone and equivalent carbonate units, which is not present under the site but nonetheless is important hydrologically. The Ochoan Series within the basin predominantly is halite and anhydrite, but also contains potash, limestone, dolomite, and fine-grained clastics. The Ochoan Series, in ascending order, includes the Castile, Salado, and Rustler Formations and the Dewey Lake Red Beds. The units above the Dewey Lake Red Beds consist of the Triassic Chinle Formation and the Santa Rosa Sandstone, small outliers of the Tertiary Ogallala Formation, and discontinuous bolson deposits of the Quaternary Gatuna Formation. A thin caliche caprock of Holocene age extends across most of the study area and locally is overlain by a shifting mantle of semi-stabilized dune sands. Holocene alluvium is present along the Pecos River.

Late Tertiary subsidence of the Delaware Basin was followed by regional uplift that caused eastward tilting of the beds in the basin. This structural deformation was later modified by local subsidence and karst development in Nash Draw, Clayton Basin, and the Malaga Bend area due to near-surface salt dissolution in the Permian evaporites.

\section{STRATIGRAPHY}

\section{Delaware Mountain Group}

The Delaware Mountain Group is part of the Guadalupian Series deposited during the Permian age and mainly is composed of fine-grained clastic rocks with a few thin limestone and shale beds. The group is divided, in ascending order, into the Brushy Canyon, Cherry Canyon, and Bell Canyon Formations. The Delaware Mountain Group is underlain by the Bone Spring Formation of Leonardian age, which consists of basinal siltstone, chert, and dark limestone. The Ochoan Series overlies the Delaware Mountain Group and 
principally consists of evaporites with increasing quantities of red mudstone and siltstone in the younger rocks. The following table lists the formations and their respective thicknesses from the Richardson and Bass, No. 1 Regan $\mathrm{H}$. Legg well (T. 22 S., R. 30 E., sec. 27) and the Clayton W. Williams, Jr., Badger Unit Federal well (T. 22 S., R. 31 E., sec. 15) near the WIPP site.

Legg we11

$\begin{array}{ll}\text { Bel1 Canyon Formation } & 1,415 \text { feet } \\ \text { Cherry Canyon Formation } & 1,050 \text { feet } \\ \text { Brushy Canyon Formation } & 1,605 \text { feet }\end{array}$

Badger Unit well

$$
\begin{array}{r}
961 \text { feet } \\
1,047 \text { feet } \\
1,936 \text { feet }
\end{array}
$$

Detailed descriptions of these formations can be found in publications by King (1948), Newell and others (1953), Hayes (1964), and Sullivan (1979). The Bell Canyon Formation is the closest water-bearing rock unit underlying the proposed WIPP facility. For this reason, the stratigraphy and hydrologic characteristics of this formation are described in detail in this report.

The Brushy Canyon Formation and Cherry Canyon Formation are composed mostly of siltstone or shales and thin fine-grained sandstone with a few thin limestone beds. Conglomerate and coarser grained sandstone are found only in the Brushy Canyon Formation (Harms, 1974). These units also interfinger with their reef-facies equivalents, the Goat Seep Limestone and San Andres Limestone (fig. 2).

Bell Canyon Formation--Stratigraphic relationships of the Bell Canyon Formation are of importance when studying the hydrology of the Delaware Mountain Group. The Bell Canyon is the fore-reef facies deposited in the Delaware Basin (Watson, 1979, p. 7). The Capitan Limestone is the reef facies equivalent to the Bell Canyon and interfingers with the Bell Canyon along the basin margin (fig. 2). The upper part of the Bell Canyon Formation was studied using cores from three test holes drilled near the WIPP site -ERDA-10, AEC-7, and AEC-8. The stratigraphic subdivisions used in the WIPP study are shown in figure 3 and are those informal members described by Grauten (1965).

Olds and Hays sandstone members: The olds sandstone member is separated from the underlying Hays sandstone (informal units) in most places by a shaly bed (Grauten, 1965, p. 298-299). The 01ds and Hays have laminated and clean sandstones facies, and they both produce some hydrocarbons in the Delaware Basin. 

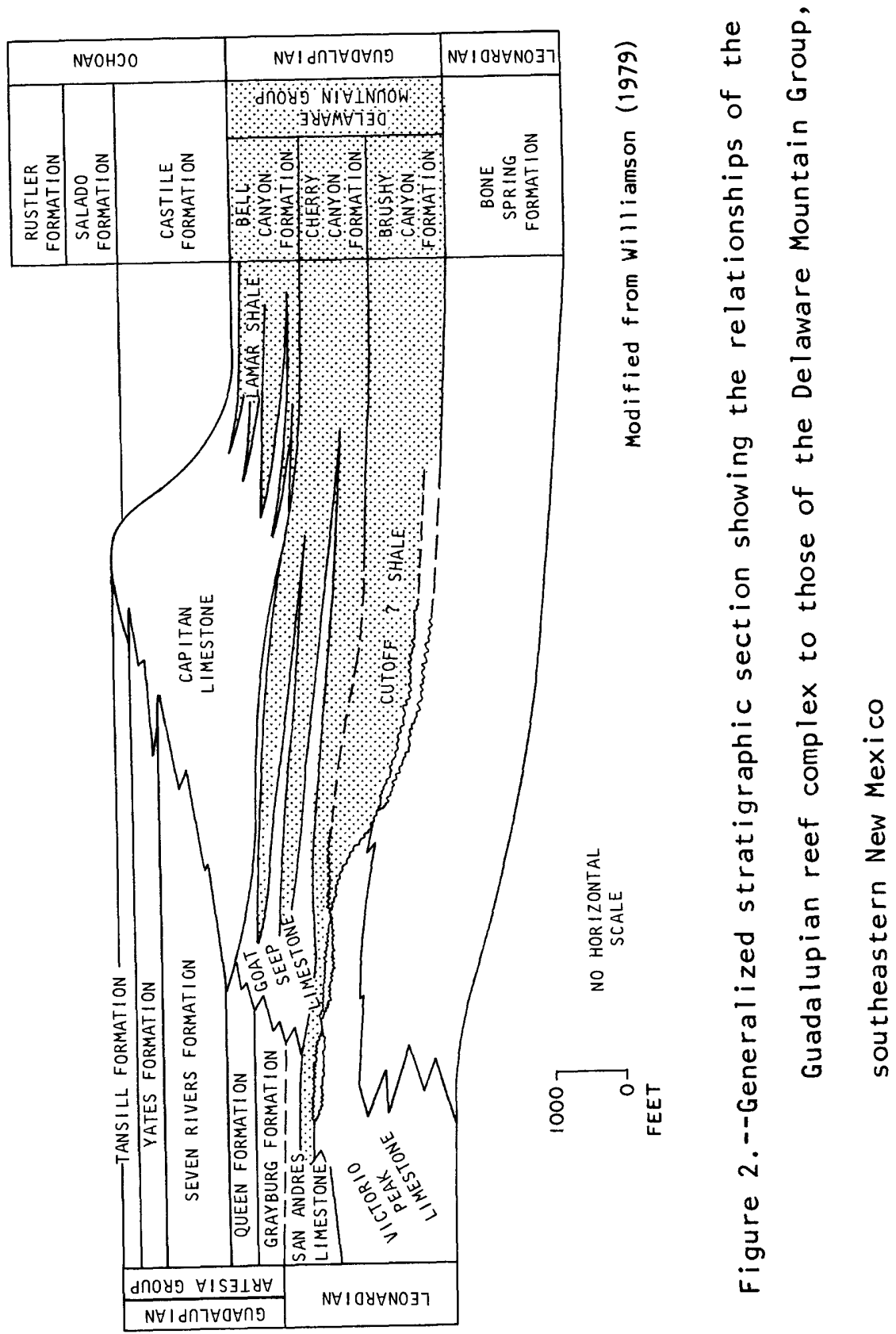


\begin{tabular}{|c|c|c|c|c|}
\hline SYSTEM & SERIES & GROUP & FORMATION & MEMBER OR ZONE \\
\hline \multirow{5}{*}{$\begin{array}{l}z \\
\alpha \\
- \\
\Sigma \\
\alpha \\
w \\
a\end{array}$} & 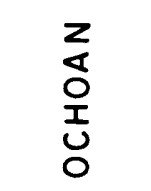 & & CASTILE & \\
\hline & \multirow[t]{3}{*}{ 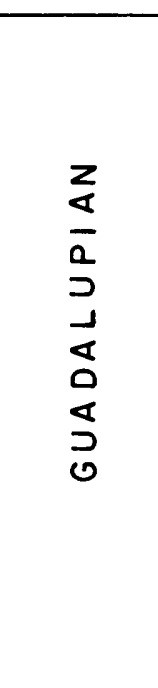 } & \multirow{3}{*}{ 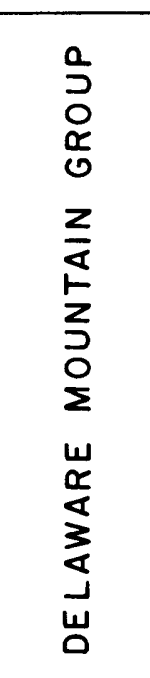 } & $\begin{array}{c}\text { BELL } \\
\text { CANYON }\end{array}$ & \multirow[t]{3}{*}{$\begin{array}{l}\text { - LAMAR SHALE MEMBER } \\
\text { - TRAP MEMBER } \\
\text { TRAMSEY SANDSTONE } \\
\text { MEMBER } \\
\text { MEMBE R } \\
\text {-FORD SHALE MEMBER } \\
\text {-OLDS SANDSTONE MEMBER } \\
\text { - HAYS SANDSTONE MEMBER }\end{array}$} \\
\hline & & & $\begin{array}{l}\text { CHERRY } \\
\text { CANYON }\end{array}$ & \\
\hline & & & $\begin{array}{l}\text { BRUSHY } \\
\text { CANYON }\end{array}$ & \\
\hline & 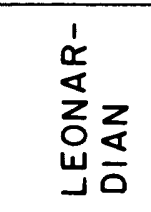 & & $\begin{array}{c}\text { BONE } \\
\text { SPRING } \\
\text { LIMESTONE }\end{array}$ & \\
\hline
\end{tabular}

Modified from Grauten (1965)

Figure 3.--Stratigraphic relationships of the Delaware Mountain Group, Texas and New Mexico 
Ford shale member: The Ford shale member (informal unit) overlies the olds sandstone member in the Delaware Basin. It consists of two 2-foot-thick beds of black shale separated by a 6-foot-thick laminated siltstone, forming one of the most important markers used in exploration for hydrocarbons in the Be11 Canyon Formation (Grauten, 1965, p. 298).

Ramsey sandstone member: The Ramsey sandstone member (informal unit) overlies the Ford member throughout the study area. As described by Grauten (1965 p. 295), the Ramsey sandstone member has two main facies: (1) A laminated, shaly siltstone, interlaminated with black shale, and (2) a clean, very fine grained sandstone with crossbeds of laminated, limy, shaly siltstone or very fine grained sandstone with interlaminae of black shale. This stratigraphic sequence is common in many of the units in the lower parts of the Delaware Mountain Group. An important characteristic of the Ramsey is that, in most instances, the clean sandstones grade laterally into laminated siltstone with negligible permeability, thus creating stratigraphic traps where hydrocarbons and other fluids may accumulate. The Ramsey is the main oil and gas producing unit of the Bell Canyon Formation.

Trap member: The Trap member (informal unit) overlies the Ramsey sandstone member and consists of an interlaminated shaly siltstone and shale sequence, the laminae of siltstone and shale being very thin (Grauten, 1965, p. 295). Some writers (Watson, 1979, p. 4) refer to this member as the upper laminated Ramsey. The Trap usually is very thin, averaging only 5 to 10 feet thick.

Lamar shale member: The uppermost member is the Lamar shale (informal unit), commonly referred to as the "Lamar lime." It is composed of a very dark, silty shale; in some places beds of hard, black, very shaly limestone are present. Throughout the Delaware Basin, the thickness of the Lamar is 25 to 30 feet.

\section{Guadalupian Reef Complex}

The Guadalupian reef complex, specifically the Capitan aquifer as defined by Hiss (1980, p. 289), is a lithosome that includes the Capitan and Goat Seep Limestones and most or all of the Carlsbad facies of Meissner (1972). It also includes shelf-margin carbonate banks or stratigraphic reefs in the upper part of the San Andres Limestone where these cannot be readily distinguished from the Goat Seep Limestone and Carlsbad facies. Generally, the units discussed are of Permian Guadalupian age and comprise a reef complex that was deposited along the margin of the Delaware Basin in a continuous, narrow, arcuate belt.

The units are composed mostly of limestones, dolomites, reef breccias (Capitan Limestone), and massive dolomites and limestones (Goat Seep Limestone). The complex includes facies transitions composed of shelf-edge 
dolomites and thin interbedded sandstones (Carlsbad facies), along with chert and dolomite (San Andres Limestone). Terrigenous clastics are notably absent in this sequence of rocks (Meissner, 1972). A more detailed description of lithologic relationships in the "reef complex" described above can be found in Hiss (1976), Meissner (1972), Motts (1968), Newell and others (1953), and Silver and Todd (1969).

\section{Ochoan Series}

The Ochoan rocks studied at the WIPP site are composed of extensive evaporite deposits that filled the Delaware Basin and extended across the Guadalupian reef zone during Permian time. The Ochoan Series is represented, in ascending order, by the Castile, Salado, and Rustler Formations, and the Dewey Lake Red Beds. The Ochoan is entirely of marine origin, but it has two dissimilar parts -- a thick lower section of evaporites and a thin upper section of red beds (Jones, 1973, p. 7). The lower section, crntaining extensive deposits of halite and anhydrite, includes the Castile, Salado, and Rustler Formations, whereas the upper section is composed of the Dewey Lake Red Beds. The Dewey Lake is composed entirely of red sandstone, siltstone, and some shale. The sequence probably forms a protective cover that has retarded the dissolution and removal of the soluble salts in the lower evaporite units (Jones, 1954, p. 107). Among the lower evaporite units, the Castile and Rustler contain more anhydrite and carbonate than the Salado. In the area of the WIPP site, these anhydrites have formed protective barriers that have retarded the upward or downward movement of meteoric water into the salt-rich Salado Formation. The ochoan sequence conformably overlies the Guadalupian Bell Canyon Formation and unconformably underlies the Triassic Santa Rosa Sandstone.

The WIPP geotechnical studies have generated intense interest in these rocks, not only because the halite of the Salado is to be the location for the proposed facility, but also because the evaporites could be barriers to fluid migration should the facility be breached. Numerous discussions of detailed stratigraphy by various authors can be found in documents published for the area (Vine, 1963; Hayes, 1964; Gard, 1968; Jones, 1954, 1973, 1978; Powers, Lambert, Shaffer, Hil1, and Weart, 1978; and Bachman, 1973, 1974, 1980, 1981); therefore, stratigraphic discussions in this paper will be limited to those deposits that may affect the hydrologic system at the WIPP site.

Castile Formation.--The Castile Formation, the basal unit in the Ochoan evaporite sequence, consists principally of anhydrite, calcite-banded anhydrite, and halite with some limestone and sandstone. As originally defined by Richardson (1904), it included all the evaporites between the Delaware Mountain Group and the Rustler Formation; however, present usage follows that of Lang (1935), who divided the Castile into two formations: the anhydrite-rich Castile below and the halite-rich Salado above. 
Extensive outcrops of the Castile Formation are present in the western part of the Delaware Basin. The formation, where it is exposed, is devoid of halite, and the anhydrite primarily has been altered to gypsum by weathering.

The contact between the Castile Formation and the overlying Salado Formation is conformable and gradational, but, nonetheless, generally is defined as the horizon at which the dominant anhydrite below changes to halite above (Jones, 1973, p. 10).

Salado Formation.--The Salado Formation, differentiated from the Castile by Lang (1935, p. 267), principally consists of halite in thick seams interbedded with anhydrite, polyhalite, and glauberite. The upper contact of the Salado is the distinct conformable contact between halite and the gray siltstone and sandstone of the lower part of the Rustler Formation. The Salado is the principal salt formation being investigated at WIPP because the proposed facility would be built in selected salt horizons of this unit. Additionally, the Salado Formation is important because parts of it (McNutt potash zone) in eastern Eddy and western Lea Counties are mined for potash minerals. A discussion related to potash evaluation can be found in Jones (1978).

Jones (1975, p. 12) describes three divisions within the Salado near the WIPP site: the lower member (1,040-1,154 feet thick), the McNutt potash zone (357-375 feet thick), and the upper member (468-504 feet thick). The lower member consists largely of clayey halite interbedded with thin seams of anhydrite and polyhalite, as well as some thin-bedded siltstones and sandstones. The lithology of the McNutt potash zone, while similar to the clayey halite of the lower member, includes sylvite and langbeinite, which are both economically important potash salts. The upper member is composed of clayey halite interbedded with minor anhydrite and polyhalite. A layer of residuum that lies immediately on top of the Salado in certain areas is considered to be residue from evaporite dissolution and is considered in this report to be part of the lower part of the Rustler Formation.

Throughout the Salado Formation, the principal lithologic types are repeated in a type of rhythmic depositional cycle that consists in ascending order of a clastic, a sulfate, a halite, and a mixed halite-clastic stratum (Jones, 1954, p. 110). Jones (1973, p. 13) interprets these rock sequences to "...represent a fundamental sedimentation unit or evaporite cyclothem."

Rustler Formation.--The Rustler Formation, named by Richardson (1904), is the youngest unit in the Ochoan evaporite sequence. The Rustler is a key marker bed of the upper Permian in Texas and New Mexico. Hydrologically this unit is one of the most extensively investigated units at the WIPP site because it contains the most productive water-bearing units in the study area.

In the vicinity of the WIPP site, Vine (1963, p. B-14) has described a five-fold division of the Rustler (fig. 4). The division includes: (1) At the base, an unnamed unit of clayey siltstone and very fine grained sandstone 
with thin interbeds of anhydrite and halite in its upper part; (2) the Culebra Dolomite Member, a unit of thin-bedded, solution-pitted, finely crystalline dolomite; (3) the Tamarisk Member, anhydrite with a single thin interbed of unconsolidated clayey silt (residuum from a thick seam of halite and associated polyhalite and halitic siltstone); (4) the Magenta Dolomite Member, a unit of thinly cross-laminated, fine-grained dolomite; and (5) the Forty-niner Member, anhydrite with a single thin interbed of unconsolidated clayey silt (residuum from a much thicker seam of clayey and silty halite). The anhydrite beds may be partially altered to gypsum in places where dissolution has occurred. The dolomite units are not only hydrologically important but are distinctive marker beds throughout the Delaware Basin (Adams, 1944, p. 1614).

The upper contact of the Rustler Formaton is represented by a distinct lithologic change, going from anhydrite to siltstone, sandstone, or shale. The discordance and hiatus between the Rustler and overlying Dewey Lake Red Beds probably are not very great.

Dewey Lake Red Beds.--The Dewey Lake Red Beds overlie the Rustler Formation in the WIPP area. This sequence was named by Page and Adams (1940) for a sequence of rocks composed of siltstone and claystone with thin lenticular beds of sandstone. As observed in many of the cores from the test holes drilled at the WIPP site, almost all of the siltstone and claystone are intruded by horizontal and crisscrossing veins of selenite. The Dewey Lake is thin bedded and contains numerous greenish-gray spots. Many of the bedding surfaces contain mud cracks and ripple marks. The Dewey Lake Red Beds range in thickness from 345 to 541 feet across the WIPP site. An erosional unconformity marks the contact between the Dewey Lake Red Beds and the overlying Santa Rosa Sandstone of Late Triassic age. 


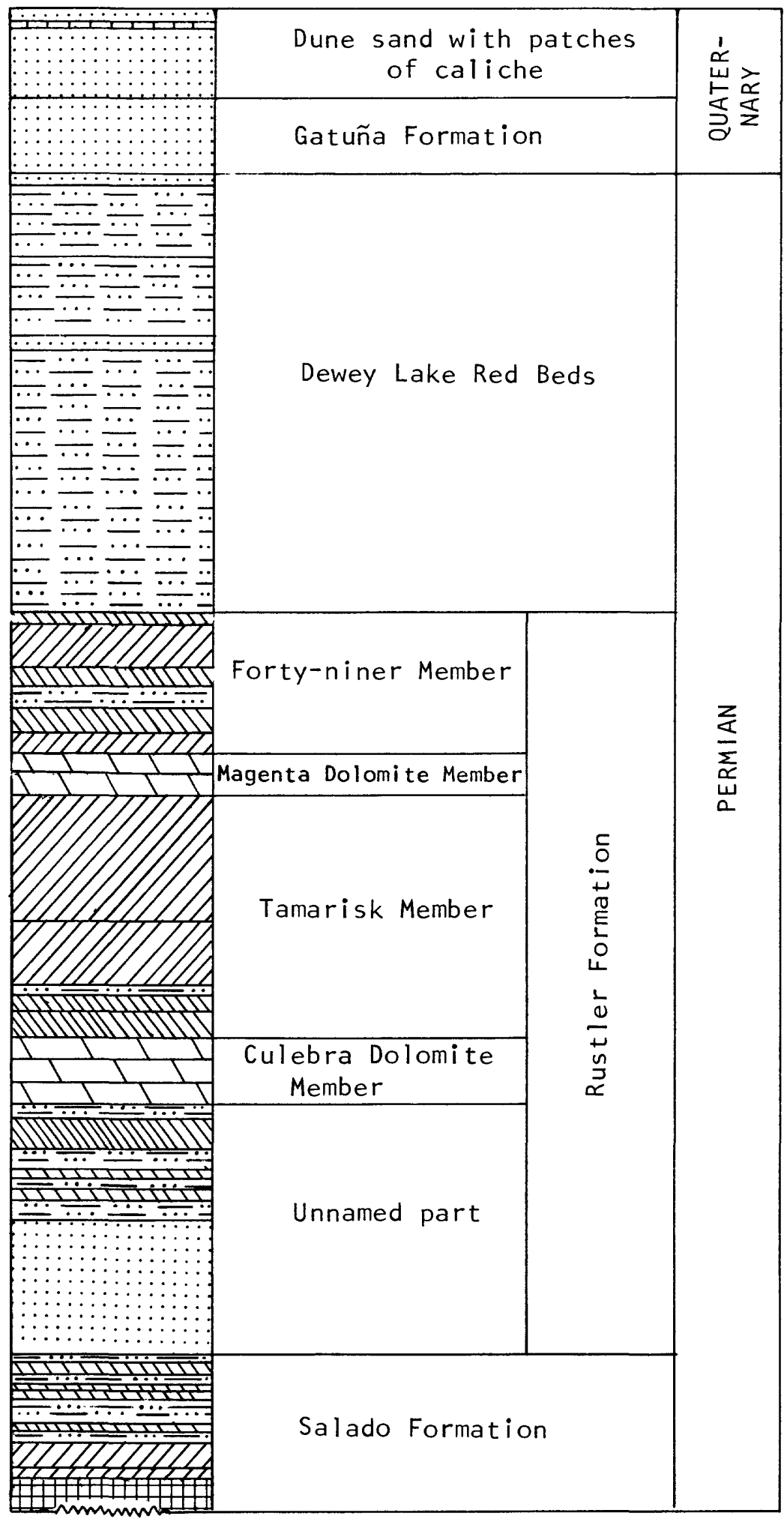

EXPLANATION

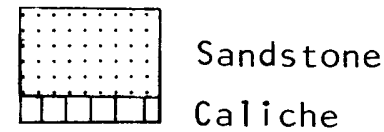

..... Siltstone

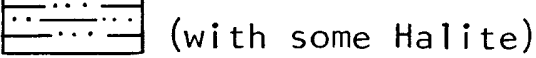
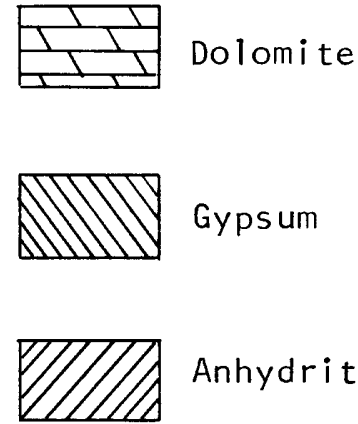
Anhydrite

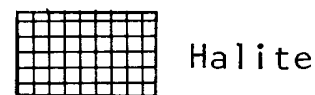

(Not to scale)

Modified from Vine (1963)

Figure 4.--The five subdivisions of the Rustler Formation in Nash Draw, Eddy County, New Mexico 


\section{Upper Triassic Rocks}

Santa Rosa Sandstone.--Triassic rocks of the WIPP area, part of the Dockum Group, include the Santa Rosa Sandstone of Darton (1922). The Santa Rosa is only present in the eastern one-half of the WIPP site (fig. 5), having been removed by erosion in the west. At the WIPP site, the Santa Rosa consists of medium- to coarse-grained, micaceous sandstone and conglomerate with interbeds of siltstone and mudstone.

The Santa Rosa Sandstone in most of the area is truncated by a nodular to laminar limestone of middle Pleistocene age, informally called the Mescalero caliche by Bachman $(1974$, p. 31). In the area east of the WIPP site, the Santa Rosa may be overlain by the Triassic Chinle Formation or a Chinle equiva?ent.

Chinle Formation.--The uppermost unit present in the Triassic Dockum Group is the Chinle Formation or an equivalent, which, although not present at the WIPP site, was penetrated in the H-10 test hole drilled 4 miles southeast of the WIPP site (fig. 1A). The Chinle Formation at the $\mathrm{H}-10$ test hole was described as a dominantly shaly mudstone interspersed with greenish-gray mudstone and lenses of sandstone and conglomerate. Anderson (1981, p. 7) discusses the presence of as much as 230 feet of Triassic Chinle Formation in test well WIPP-15 in San Simon Swale, which is 10 miles east of the WIPP site. According to Nicholson and Clebsch (1961, p. 35), confusion exists due to lithologic similarities between the Chinle and Santa Rosa, which they believe cannot be separated. In fact, Bachman (1980, p. 26) believes that there is little justification to even extend these formation names into southeastern New Mexico and that the sequence should be simply referred to as Triassic or Dockum Group undivided. Although problems in nomenclature have been created concerning the Triassic Chinle Formation, this report retains the formation names and uses them, at least in the vicinity of the WIPP site. 


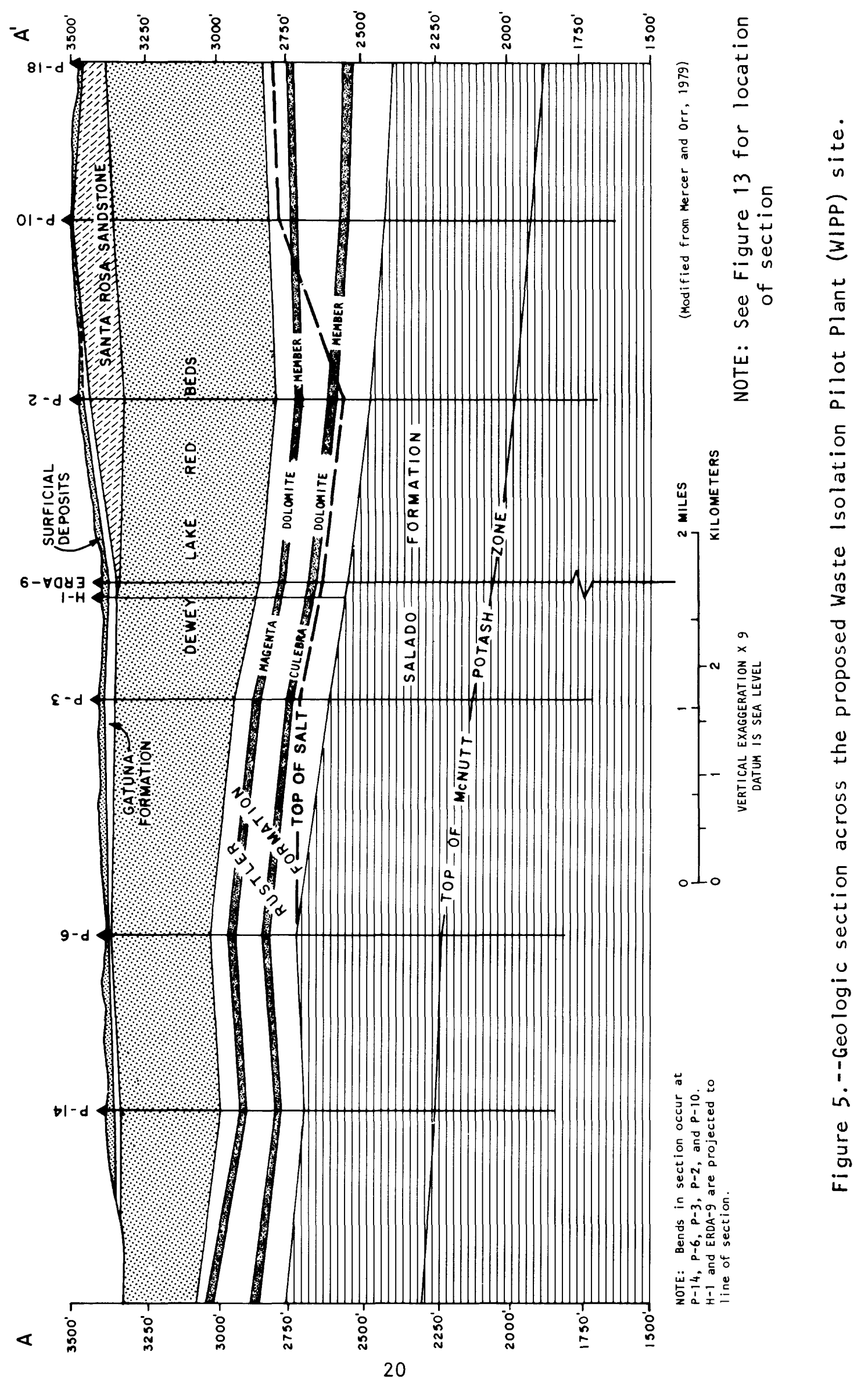




\section{Tertiary and Quaternary Rocks}

Tertiary and Quaternary deposits in the vicinity of the WIPP site include the Ogallala Formation of Miocene age, the Gatuña Formation of Pleistocene age, and sands, playa deposits, caliche, and alluvium of Holocene age. These units cover the surface of nearly the whole region and lie unconformably on older rocks.

Ogallala Formation.--The Ogallala Formation of Miocene age is the oldest record of Cenozoic depositional history and climate preserved in southeastern New Mexico (Bachman, 1980, p. 34). Although the Ogallala is well exposed along Mescalero Ridge, at Hat Mesa, Gramma Ridge, and at the Divide (fig. 1 and la), Bachman $(1980$, p. 34) indicated that the Ogallala Formation could not be recognized west of San Simon Swale towards the WIPP site except for a few thin outliers near the Divide.

In southeastern New Mexico, the Ogallala Formation generally is described as a well-sorted, windblown sand with minor poorly sorted stream deposits and carbonate pans that are usually capped by a rather resistant layer of well-indurated caliche. Bachman $(1980$, p. 35) reports that even though the upper surface is relatively smooth, the irregular surface on which it was deposited has resulted in irregular thicknesses for the Ogallala.

Gatuña Formation.--The Gatuña Formation is the oldest known Quaternary formation in the study area and probably the thickest though the least extensive. The Gatuña was named by Robinson and Lang (1938, p. 84-85) and occurs as discontinuous bolson-type deposits in channels and depressions, possibly related to solution within the Salado and Rustler Formations. Bachman (1976, p. 140) describes a reference section of the Gatuna in the vicinity of Gatuña Canyon that consists of sandstone, siltstone, and conglomerate, with the conglomeratic beds containing pebbles of quartz and quartzite reworked from Triassic conglomerates.

Mescalero caliche.--The Mescalero caliche, an informal stratigraphic unit named for the Mescalero Plain (a broad geomorphic surface in southeastern New Mexico), occurs east of the Pecos River and west of the High Plains (Bachman, 1976, p. 141). The caliche is a well-lithified alluvial deposit of chalky, finely crystalline limestone. The caliche caps the geomorphic surface and lies with angular unconformity on the underlying Gatuna and older formations; its lower part commonly engulfs large masses of older bedrock.

Alluvium and other surficial deposits.--There are no through-flowing streams in the immediate area of the WIPP site; therefore, there are no recent stream deposits of any magnitude. Surficial deposits are composed mostly of locally derived materials deposited by sheet wash. In some parts of the area, such as Nash Draw, the surficial deposits include gypsum and dolomite fragments derived from the Rustler Formation as well as caliche fragments from the 
Mescalero caliche. There are small intermittent streams and collapse features that, although they may be discontinous, do contain alluvial sand and silt that is locally conglomeratic.

Hummocky surficial deposits of dune sand cover almost the entire WIPP site. The sand, locally known as the Mescalero sand (Vine, 1963, p. B-36), is fine to medium grained, with the grains predominantly angular to subrounded. Although the sand may occur as dune ridges, most of it is present on the flats and is generally stabilized by mesquite and other vegetation.

The most extensive deposits of true alluvium in the vicinity of the WIPP site are present along the west side of the Pecos River north of Malaga Bend. Isolated patches of alluvium are present to the south of Malaga Bend, but these are not very extensive.

Alluvium east of the Pecos is localized and present in depressions, as in Clayton Basin and Nash Draw. The thickest alluvial deposits, however, were found in San Simon Swale 10 miles east of the WIPP site, where drilling at WIPP-15 penetrated about 547 feet of fill (Sandia National Laboratories and the University of New Mexico, 1981, p. 7).

Maley and Huffington (1953) and Cooper (1962b, p. E152) have described several structural features in the study area as thick accumulations of alluvium that fill deep solution depressions. Nicolson and Clebsch (1961, p. 46-47) describe similar collapse structures in southern Lea County. These studies show that alluvial deposits underlie an area of 150 square miles east of the Pecos River in Eddy County, New Mexico, and extend southward into western Texas (fig. 6). Maley and Huffington (1953, pl. 1) indicate more than 1,400 feet of fill at the center of this area near the New Mexico-Texas State line, but Cooper's investigations show that, at least in New Mexico, the thickness probably does not exceed 1,000 feet. Lithologic descriptions from logs of several holes drilled into the fill indicate the material to be sands separated by somewhat thicker interbeds of silt and clay.

Other surficial material in the WIPP site area includes the fill associated with playas. This material generally consists of alluvium and eolian sands reworked by lake waters but may also contain reworked gypsum as well as precipitated gypsum and chlorides, as is present at Laguna Grande de la Sal. Some playas may contain perennial lakes, such as Laguna Grande de la Sa1; others may be dry most of the year. 

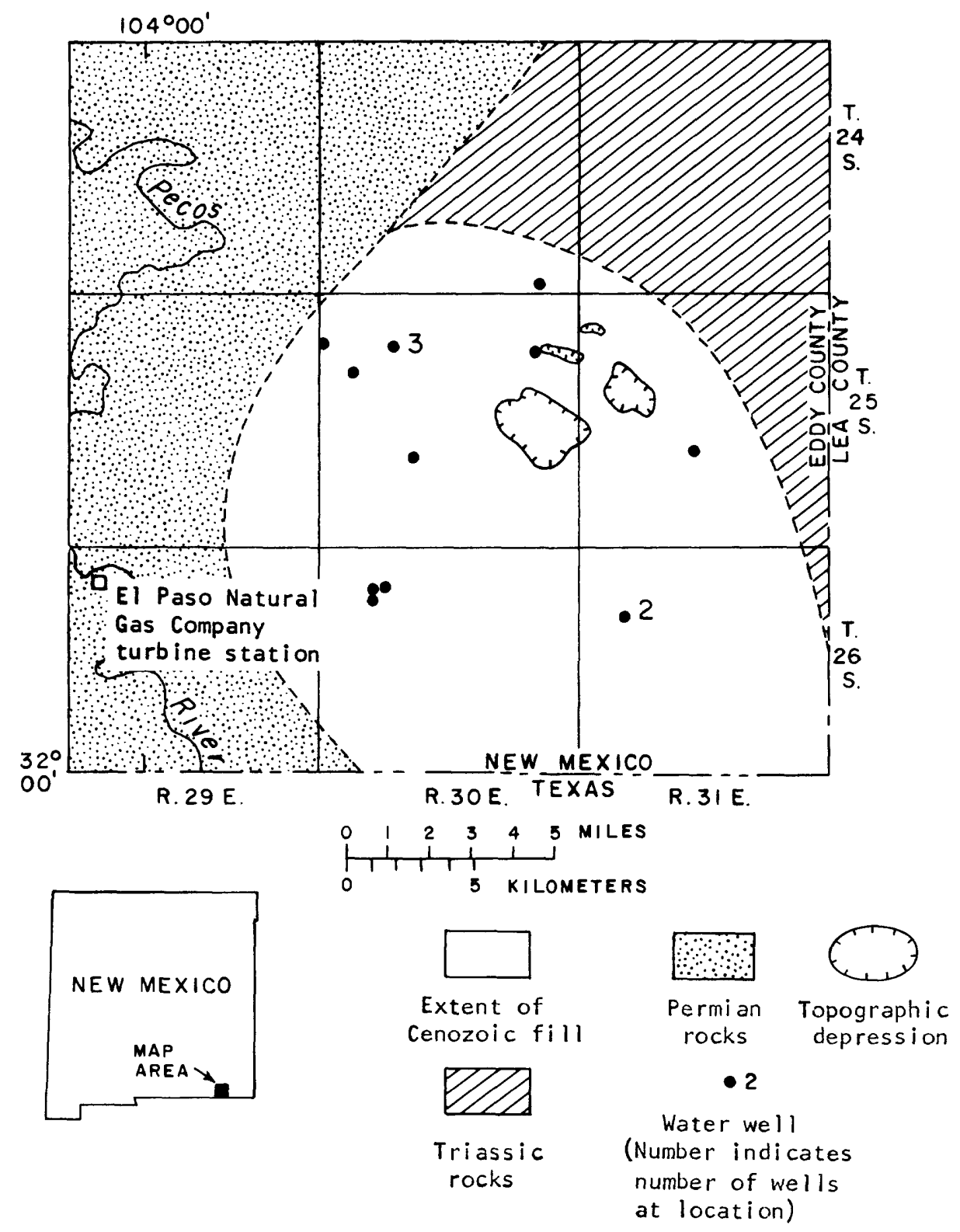

From Cooper (1962)

Figure 6.--Generalized subsurface extent of Cenozoic fill in southeastern Eddy County, New Mexico 


\section{GROUND-WATER HYDROLOGY}

This report presents an appraisal of potential boundaries to the ground-water flow system in the vicinity of the WIPP site and includes an evaluation of hydraulic flow paths from the facility to the proposed major discharge area at Malaga Bend. The hydrologic regime both above and below the facility needs to be examined in order to characterize the flow system in the WIPP site study area, particularly when the host medium for the storage facility consists of easily dissolved halite. Therefore, the studies were divided into shallow hydrologic investigations (above salt) and deep hydrologic investigations (below salt). The phases of the shallow and deep hydrologic investigations included: the geology of the area, the stratigraphic location of the geohydrologic units and the occurrence of water in them, the hydraulic factors that govern ground-water movement from areas of recharge to areas of discharge, and the chemical quality of water and possible reactions with the host rocks.

The fundamental principles governing the occurrence and movement of ground water have been discussed in detail in textbooks and numerous publications, for example Meinzer (1923a and b), Tolman (1937), and Lohman (1972). The interested reader is referred to these publications and others for a more detailed discussion of this subject.

The terminology for hydraulic properties of ground-water systems has caused some confusion in the past. For example, the use of permeability and hydraulic conductivity interchangeably has led to much of the confusion, especially between ground-water hydrologists and petroleum engineers. In this paper, hydraulic conductivity will be used when referring to the water-transmitting characteristic of the material in quantitative terms. The definition of hydraulic conductivity used here is the one described in Lohman (1972, p. 6) and is a replacement for the older term, "coefficient of permeability." "A medium has a hydraulic conductivity of unit length per unit time if it will transmit in a unit time a unit volume of ground water at the prevailing viscosity through a cross section of unit area, measured at right angles to the direction of flow, under a hydraulic gradient of unit change in head through the unit length of flow." In this report, permeability will be used as a qualitative term to refer in a general way to the ability of a rock to transmit fluid. The "permeability" commonly used by petroleum engineers will be the "intrinsic permeability" described by Lohman (1972). The "intrinsic permeability" is a property only of the medium and is independent of the nature and properties of the fluid contained in it.

Transmissivity is a term used in this report that also needs definition. As defined by Lohman (1972, p. 6), transmissivity is the rate at which water of the prevailing kinematic viscosity is transmitted through a unit width of the aquifer under a unit hydraulic gradient. It is both a property of the aquifer and of the confined liquid. The transmissivity is equal to the average hydraulic conductivity times the thickness of the aquifer. The term 
"aquifer" is not used in its formal sense in this report. Formal usage defines an aquifer as a geologic formation or group of formations or a part of a formation that is capable of yielding economic quantities of water to a pumped well or to springs. The use of the term aquifer in reference to most water-bearing zones at WIPP would be misleading. More appropriately these zones will be referred to as "hydrologic units" or "water-bearing zones" in this report.

Ground water exists under hydrostatic pressure and its movement generally is from places of higher potential or hydraulic head to places of lower potential or hydraulic head. The hydraulic head, at any point, is usually expressed as the elevation above a fixed datum (usually sea level) to which water will rise in a tightly cased hole. Differences in hydraulic head in feet of water within a hydrologic unit and the resulting slope of the profile is called the hydraulic gradient.

Rates of movement between any two points in a water-bearing unit depends on the difference in hydraulic head, the distance between the points, the effective porosity of the unit, and the hydraulic conductivity.

The distribution of water levels measured in wells in selected hydrologic units is illustrated by contours on maps; in confined ground-water systems, these maps are referred to as potentiometric-surface maps. The potentiometric surface is the elevation to which water will rise in tightly cased wells that penetrate confined hydrologic units; the imaginary surface thus defined is used to picture the areal extent and movement of ground water as well as to qualitatively define any permeability changes within the unit. In some instances potentiometric-surface maps can be useful for predicting directions of ground-water flow. In general, the primary direction of water flow in porous media is at right angles to the potentiometric-surface contours. However, in cases of fracture flow, as occurs locally at the WIPP site, the direction of movement is most affected by directional differences in permeability or fracture orientation. Thus, the actual direction may have little or no relationship to the movement inferred from the regional potentiometric-surface contours. Where extensive fracturing has occurred, the flow could actually be almost parallel to the indicated gradient. Earlier maps constricted for the WIPP study area have failed to distinguish between water levels of different hydrologic units. Present potentiometric maps distinguish the three water-bearing units and show equivalent freshwater-head differences in excess of 100 feet between units.

Potentiometric-surface maps for the WIPP study area need to include effects from variations in water chemistry within the individual water-bearing zones. These variations create density differences that hinder determination of representative static-pressure heads. A potentiometricsurface map constructed strictly on the existing water levels, without appropriate density correction, may lead to erroneous conclusions when efforts are made to determine flow direction from this potentiometric gradient. Various methods of correction were studied, as described in Bond 
(1972), Hubbert (1953), and Jorgensen and others (1982). However, it was determined for this report that the water levels would be adjusted to a common density of 1.0 (freshwater equivalent) by methods similar to those described in Hiss (1976). Because the units are almost horizontal, this method is believed to give reasonable values for general directions of flow (the Hiss method is not accurate for dipping beds). Larger errors can occur in hydraulic-head calculations, adjusted for density, when thick water-bearing beds are present (not the case at the WIPP site), and especially when density varies in the vertical direction as well as in the horizontal direction. The hydrologic units at the WIPP site include thin water-bearing beds where density variations are primarily lateral, not both lateral and vertical.

As ground water moves along the flow system from recharge areas to areas of discharge, its chemical quality is altered by a variety of geochemical processes. As the ground water moves along the flow path, the concentrations of dissolved solids probably increase, especially if the water comes in contact with easily dissolved halite and other evaporite rocks.

Large concentrations of dissolved solids were found in most of the water samples collected from the hydrologic units studied at WIPP; in most instances the ground water would be classified as moderately to very saline (3,000 to 35,000 milligrams per liter of dissolved solids) to brines (more than 35,000 milligrams per liter of dissolved solids). The concentrations of the major chemical constituents are directly related to the interaction of the host rocks with the water, which moves slowly through them because of restricted circulation. Interpretation of hydrochemical analyses from these rocks has aided in the understanding of the hydrologic mechanisms at work in the rocks below and above the proposed storage horizon. To facilitate an understanding of these mechanisms, discussions of the water chemistry in this report are included with the hydrologic discussions of the individual units. Although the geochemical complexity of the ground water in the WIPP area cannot be completely understood from the chemistry of the dissolved ions alone, the chemistry does provide a qualitative insight into the chemical history of these waters and some of the complexities associated with ground-water movement.

\section{Hydrology of the Delaware Mountain Group}

Geohydrologic characteristics.--The lithology of the Delaware Mountain Group has been described previously in detail. It is predominantly a fine-grained, silty sandstone with interbeds of black shale and black limestone. The basinal deposits are composed, in ascending order, of the Brushy Canyon, Cherry Canyon, and Bell Canyon Formations. The Delaware Mountain Group crops out in the southern Guadalupe Mountains and in the Delaware Mountains in Texas. The maximum thickness of the Delaware Mountain Group is in the 
central part of the Delaware Basin where it exceeds 4,000 feet. The Delaware Mountain Group either pinches out or interfingers with the several stages of reef facies on the basin edge (fig. 2).

A structure-contour map (fig. 7) on top of the Lamar shale member (informal unit) of the Bell Canyon Formation of the Delaware Mountain Group shows two main types of structural provinces -- monoclinal in the west and anticlinal in the east, southeast, and the southwest (Grauten, 1965, p. 299). The Lamar shale has a general eastward dip of about 75 to 100 feet per mile.

The Cherry Canyon and Brushy Canyon Formations produce only minor quantities of oil and gas; most of the oil and gas comes from sandstone in the upper part of the Bell Canyon Formation. The oil fields developed in the upper part of the Bell Canyon do not usually occur in any pronounced structural feature that could account for the trap. 0il, gas, and water probably occur in relatively clean elongated "channel" sandstones that are porous and permeable but grade vertically and laterally into relatively impermeable siltstones and laminated shales. These rocks form permeability barriers, thus creating stratigraphic traps. The Cherry Canyon Formation contains less oil and gas, not only because of a lack of favorable structural features such as are found in the Bell Canyon, but also because of a large proportion of siltstone and increased cementation that decrease the permeability. Similarly the Brushy Canyon Formation probably contains little oil or gas because of lesser permeability from increased cementation (Berg, 1979, p. 89). Berg also concludes that the greater permeabilities found in the upper sandstones of the Bell Canyon probably result from their shallower depth and lesser cementation.

Data for a regional analysis of the hydrologic characteristics of water-bearing units within the Delaware Mountain Group are sparse due to the depth, the salinity of the water, and the overall lack of permeability of these rocks. Early studies (Grauten, 1965, and Sullivan, 1979) of the Delaware Mountain Group concluded that the Lamar shale at the top of the Bell Canyon Formation plus the several thousand feet of dense anhydrite and salt of the overlying Castile Formation would probably form effective confining beds over the Bell Canyon Formation. These confining beds, if they were not fractured, would restrict water from migrating upward from the Bell Canyon Formation to dissolve the salt of the Salado Formation and would also restrict movement of fluids downward from the proposed facility horizon to the Bell Canyon Formation. Since these studies, interpretations of the potential for upward movement of fluids from the Bell Canyon into the overlying evaporites (Anderson, 1978, 1981) have created a need for a re-evaluation of the hydrologic system of the Delaware Mountain Group.

This study is restricted to the upper part of the Bell Canyon Formation because it is the closest water-bearing zone below the evaporites and contains the most porous sandstones of the Delaware Mountain Group. The hydrologic system of the Delaware Mountain Group, as defined by the available 


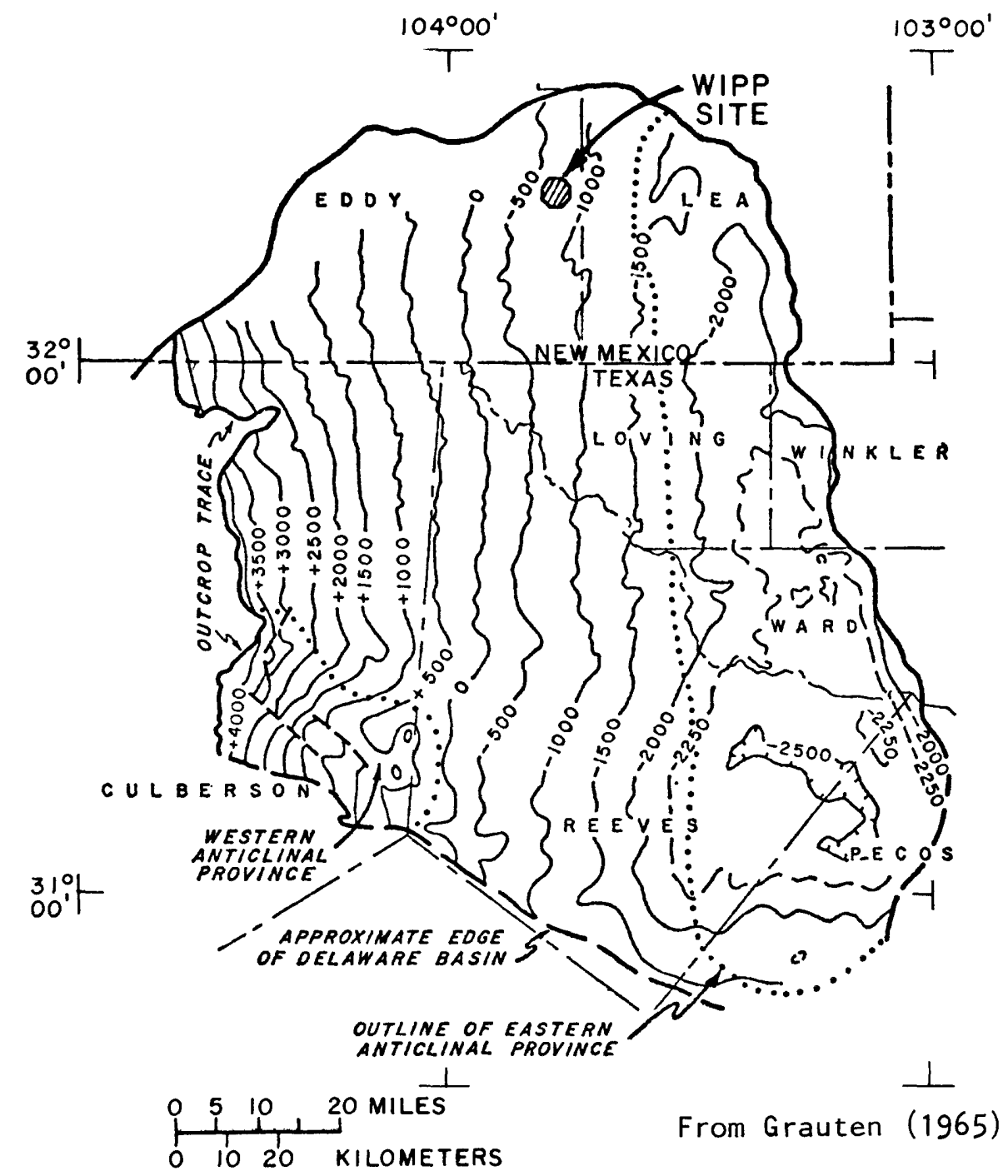

\section{EXPLANATION}

$\sim 1500 \Omega$ STRUCTURE CONTOUR--Shows altitude of top of Delaware Mountain Group. Dashed where approximately located.

Contour intervals 250 and 500 feet. Datum is sea level.

Figure 7.--Generalized structure contours on top of the Lamar shale (informal unit) of the Bell Canyon Formation (Delaware Mountain Group) in the Delaware Basin, New Mexico and Texas 
data, probably is confined to the upper 600 feet of the Bell Canyon Formation; individual sandstone units in any one area probably are no thicker than 45 to 60 feet.

Based on drill-stem tests conducted on the Bell Canyon Formation and from data from previous studies, it became apparent that earlier studies (Hiss, 1976; Mercer and Orr, 1977) that indicated that the Delaware Mountain Group is a uniform hydrologic unit were in error. Numerous studies of oil reservoirs indicate that the sandstones of the upper part of the Bell Canyon are present as narrow, sinuous channels that grade laterally into less permeable shales and siltstones. These channel sandstones may be covered with siltstone and locally are poorly connected hydrologic units. Though studies of geophysical logs may indicate that it is continuous, each major sandstone body is composed of many individual sandstone beds that are either separated by siltstone or have different degrees of cementation (Williamson, 1979, p. 71). Grauten (1965) describes the apparently continuous sands of the Ramsey sandstone actually to be composed of three or more separate sublenses of porous sandstone separated by relatively impermeable siltstone beds, each sublens to be virtually separated hydraulically from the others. The entire system is confined by overlying beds with negligible permeability; in the case of the sandstones of the Ramsey member, the overlying Trap and Lamar shale members form a very effective seal (Grauten, 1965, p. 302). As a result, vertical permeability within these sandstone units is very small. This very small vertical permeability is indicated by data from a drill-stem test in test well AEC-8 where two sandstone units, separated by a siltstone unit 16 feet thick, were individually tested (Mercer and Orr, 1979, p. 133). The water levels for the upper and lower sandstones stabilized at 553 and 568 feet below land surface. Extensive evaluation of drill-stem tests in other wells throughout the basin indicated that differences of this magnitude are common. These differences indicate that confining beds between the sandstones are so poorly connected that they cause hydraulic-head differences of 15 feet in sandstone lenses only 16 feet apart.

The hydraulic properties of the upper part of the Bell Canyon have been compiled from several sources including drill-stem tests at the WIPP site (table 4) and selected oil-field production data. The following discussion provides the average values for hydraulic properties published in the Delaware Mountain Group Symposium (Sullivan, 1979) for reservoirs at which oil, gas, and water are present and includes the values for the hydraulic properties for the permeability barriers of siltstone and shale.

The primary porosity of the upper Bell Canyon sandstones (generally the Ramsey) is intergranular and generally ranges from 20 to 28 percent. The permeabilities of these sandstones in the Ramsey range from 14 to 90 millidarcies (Berg, 1979) although permeability may be greater locally. The siltstones and shaly siltstones forming the permeability barriers generally have porosities ranging from 10 to 20 percent with a permeability usually less than 0.1 millidarcy. A good example of this type of stratigraphy is shown in the cross section across the El Mar oil field in Loving County, Texas (fig. 8). 


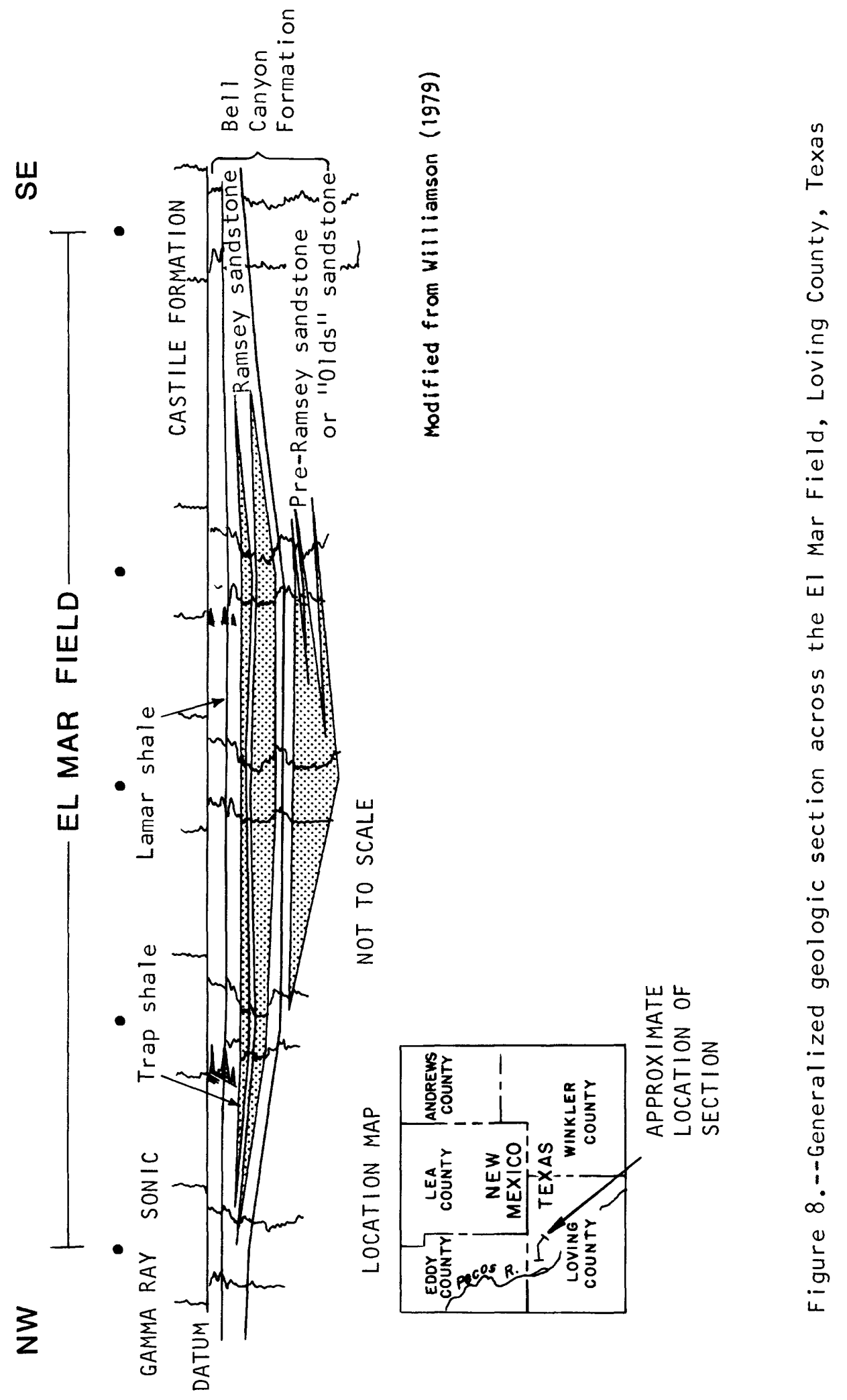


The unknown factor in this analysis is the degree to which the sandstones are interconnected on a regional scale. If the siltstone barriers also are present on a regional scale, the permeability values given for the sandstones are probably too large, and calculated rates of movement are also too large. The permeability barriers, however, are present locally.

Three test holes (AEC-7, AEC-8, and ERDA-10) were drilled into the upper part of the Bell Canyon Formation and were hydraulically tested to evaluate the deep water-bearing units in the Bell Canyon Formation in the vicinity of the WIPP site. Several sand stringers that were identified from the geophysical logs and cores were permeable enough to test and contained brine. These zones included an upper and lower sand in test hole AEC-8 (probably pre-Ramsey), a series of sandstones in test hole ERDA-10 (Ramsey and pre-Ramsey), and sandstone in test hole AEC-7 (Ramsey). Although test holes AEC-8 and ERDA-10 are only about 14 miles apart and the sandstones tested are about the same depth below the top of the Bell Canyon, they may not be in good hydraulic connection because they appear to be channel sandstones. Test hole AEC-7 penetrated similar sandstones at a shallower depth.

The tests were conducted using standard and modified drill-stem-test procedures (Mercer and Orr, 1979), which primarily test the horizontal hydraulic conductivity. From analyses of the hydraulic data (table 4), the hydraulic conductivities of the sandstones were $4.0 \times 10^{-2}$ foot per day for the zone tested in $\mathrm{AEC}-7,2.0 \times 10^{-2}$ and $7.0 \times 10^{-3}$ foot per day for the two zones tested in $\mathrm{AEC}-8$; and $5 \times 10^{-2}$ foot per day for the zone tested in ERDA-10. The Lamar shale also was tested in the three holes to evaluate the effectiveness of the zone as a confining bed which would restrict upward movement of fluids, assuming the unit is not fractured. The tests of the Lamar shale yielded values of hydraulic conductivity of $2.0 \times 10^{-6}$ foot per day in test hole AEC- 8 and $4.0 \times 10^{-4}$ foot per day in test hole ERDA-10. In AEC-7, the Lamar shale was evaluated to determine its effectiveness as a confining bed, but it had such negligible permeability it could not be tested. These hydraulic-conductivity values for the upper sandstone of the Bell Canyon were within the range of permeability values reported by various oil companies for the sandstones and shales of the Delaware Mountain Group throughout the basin. These tests also indicated that the head in the upper part of the Bell Canyon Formation, although it extends above the lower part of the Rustler Formation, is still less than the heads in the Rustler Formation. Therefore, the potential is for downward movement if these zones were interconnected.

Ground-water movement.--Several studies have produced potentiometric-surface maps for the Delaware Mountain Group; however, because most of the pressure-head information comes from the upper part of the Bell Canyon, these maps probably are most representative of that zone. The common procedure during oil exploration is to run a drill-stem test on a zone that (from geophysical logs) appears to have the greatest porosity along with some associated permeability. Because of the lack of lateral continuity in many of the sandstones tested in the upper part of the Bell Canyon, less reliable 
data are available than would be expected from the number of wells shown on an oil and gas map.

Hiss (1976) and McNeal (1965) have constructed potentiometric-surface maps for the upper part of the Be11 Canyon Formation, and the maps generally are similar even though Hiss's map only covers the northern part of the Delaware Basin. Both of these maps were constructed after adjusting hydraulic head data to a freshwater equivalent to account for variations in brine density. In the WIPP characterization study, available oil-field drill-stem tests, production tests, and water analyses were coupled with data collected from the deep test holes AEC-7, AEC-8, and ERDA-10 near the WIPP site to construct a potentiometric-surface map. The base map developed by Hiss (1976) was used and new information was corrected for density as described by Hiss and incorporated in a new map. The new contour map duplicated Hiss's map with very little modification (fig. 9).

The potentiometric gradient of the upper part of the Bell Canyon is nearly parallel with the regional structural trend. Water apparently enters the unit in the western part of the basin, perhaps in the Delaware and Guadalupe Mountains, and moves northeastward across the basin at a hydraulic gradient ranging from 25 to 40 feet per mile. The rate of water movement in the sandstone is probably very slow because it is assumed to be restricted by negligible hydraulic conductivity of the intervening siltstones. Although the Capitan aquifer of Hiss (1976) abuts and overlies the Delaware Mountain Group along the basin margins, the lithologic and hydrologic characteristics of the Capitan aquifer and Delaware Mountain Group (in particular the upper part of the Bell Canyon Formation) are quite different (Hiss, 1980, p. 289). The hydraulic conductivity of the Delaware Mountain Group is several orders of magnitude less than that of the Capitan aquifer; this fact, coupled with differences in quality of water, would indicate that only a relatively small quantity of water in the Delaware Mountain Group, if any, would move into the Capitan aquifer. Data from tests of the upper part of the Bell Canyon Formation in test holes $\mathrm{AEC}-7, \mathrm{AEC}-8$, and ERDA-10 fit with the regional trend. Fluid density and permeability variations and discontinuity of the upper sandstone units in the Bell Canyon preclude detailed site-specific analyses by means of the potentiometric-surface map.

Hydrochemistry.--Generally, the waters in the upper part of the Bell Canyon Formation are brines in which sodium and chloride are the predominant ions (table 5). The "clean" sandstones near the outcrop of the Ramsey sandstone of the Bell Canyon appear to be saturated with relatively freshwater (Grauten, 1965, p. 303). As the water moves across the Delaware Basin, however, the salinity of the water increases; locally dissolved-solids concentrations of more than 300,000 milligrams per liter occur in the structural trough of the basin (McNea1, 1965, p. 317). Concentrations of dissolved solids in brines sampled during the testing of the upper part of the Be11 Canyon at the WIPP site ranged from 180,000 milligrams per liter in test hole AEC-8 to 270,000 milligrams per liter in test hole ERDA-10 (table 2). The abundance of calcium, magnesium, sodium, and potassium 

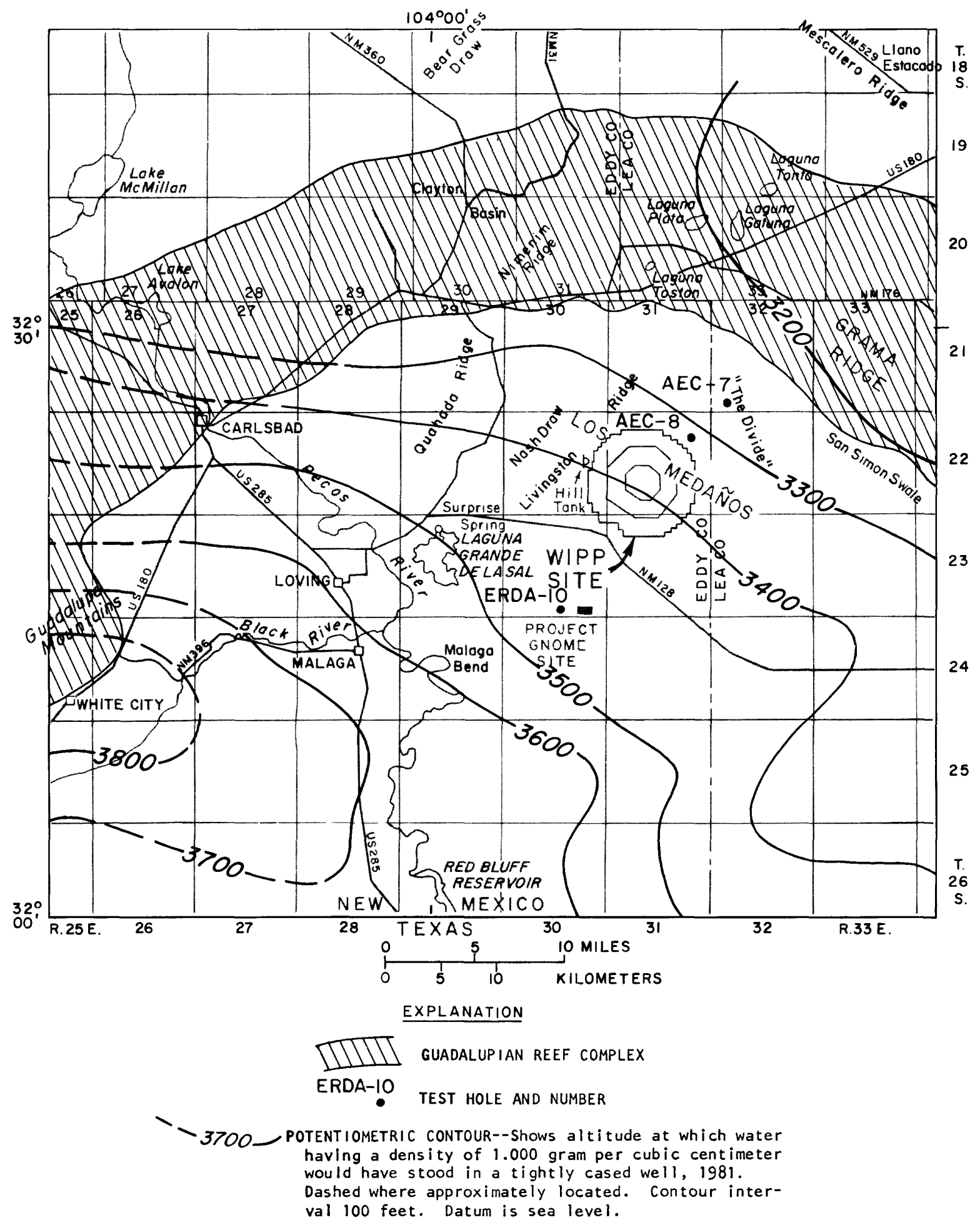

Figure 9.--Potentiometric surface of the hydrologic unit in the upper part of the Bell Canyon Formation (Delaware Mountain Group) at and near the proposed Waste Isolation Pilot Plant (WIPP) site 
cations, the presence of chloride and sulfate as the major anions, and the measured low hydraulic conductivity support the concept of extensive brine-rock interaction as the water moves slowly northeastward across the basin. Detailed information on the composition of the water from the Bell Canyon in test holes AEC-7, AEC-8, and ERDA-10 is included in table 2 .

\section{Hydrology of the Guadalupian Reef Complex}

Geohydrologic characteristics.--In general, the position and dimensions of the Guadalupian reef complex, which contains the Capitan aquifer as defined by Hiss $(1976,1980)$ and as used in this report, closely agree with the location of the Capitan and Goat Seep Limestones and carbonate banks of the Carlsbad facies of Meissner (1972). It also includes shelf-margin carbonates and the upper part of the San Andres Limestone. Although the Capitan aquifer is one of the most productive aquifers in southeastern New Mexico, it is present in the subsurface, at the closest, some 10 miles north of the proposed WIPP facility. Here, the Capitan aquifer is generally composed of a relatively "clean" carbonate with low insoluable residue, especially near the forereef edge.

This report is concerned with the section of the Capitan aquifer that parallels the northern and eastern margins of the Delaware Basin in an arcuate strip that extends from the Guadalupe Mountains southwest of Carlsbad to the Glass Mountains near Fort Stockton, Texas. The width of the Capitan aquifer in this strip ranges from 10 to more than 14 miles (Hiss, 1976, p. 141). In the subsurface, the forereef edge is relatively abrupt and abuts against the sediments of the basin (fig. 10). Approximately 1,200 feet of vertical relief along the forereef edge was detected in two oil test holes drilled a few hundred feet apart (horizontal distance) in sections 5 and 9, T. 22 S., R. 33 E. in Lea County (Hiss, 1976, fig. 18). The backreef edge of the Capitan aquifer is much more irregular. The thickness of the unit is quite variable. A maximum thickness of nearly 2,400 feet is present about 13 miles northeast of Carlsbad.

Hiss (1976, p. 90) reported that a thickness of more than 1,500 feet has been observed in 49 percent of the wells that penetrate the Capitan aquifer in New Mexico. He also discussed the presence of submarine canyons that eroded into the reef in Eddy and Lea Counties, New Mexico, which decrease the overall thickness of the aquifer by one-half or more. These features all have a bearing on the occurrence and movement of water in the reef complex.

Hiss (1976, p. 198) calculated the hydraulic conductivity of the Capitan aquifer along the eastern margin of the Delaware Basin in Texas and New Mexico to range from 1 to 25 feet per day; average values for the aquifer in southern Lea County and east of the Pecos River valley at Carlsbad are about 5 feet per day. Although no values of hydraulic conductivity are available 

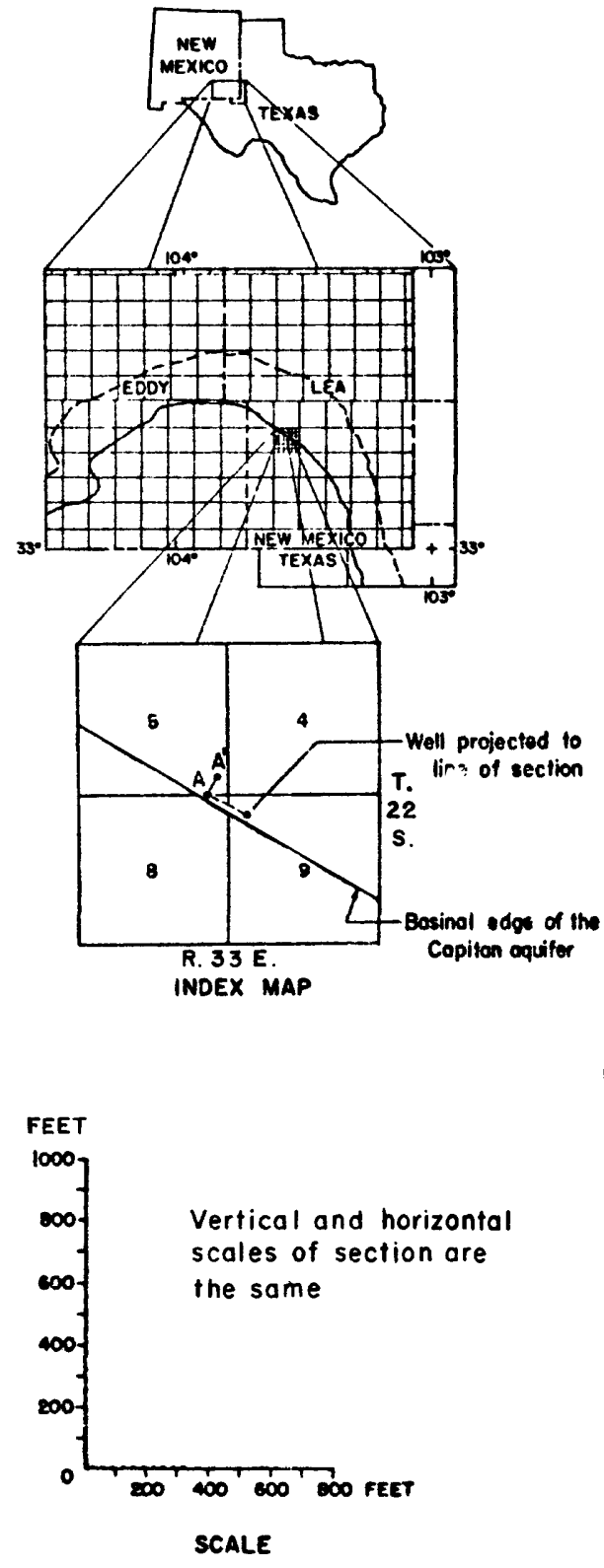

Dual-Drilling Co.

Hudson-Federal

660 feet from north 1 ine and

660 feet from west 1 ine of

Sec. 9, T.22 S., R.33 E.

Lea County, New Mexico

Ground level: 3,632 feet

Total depth: 5,027 feet
Dual Drilling Co.

Richardson-Bass State 1

660 feet from south line and

330 feet from east line of Sec. 5,

T.22 S., R. 33 E., Lea County,

New Mexico

Ground level: 3,650 feet

Total depth: 6,065 feet

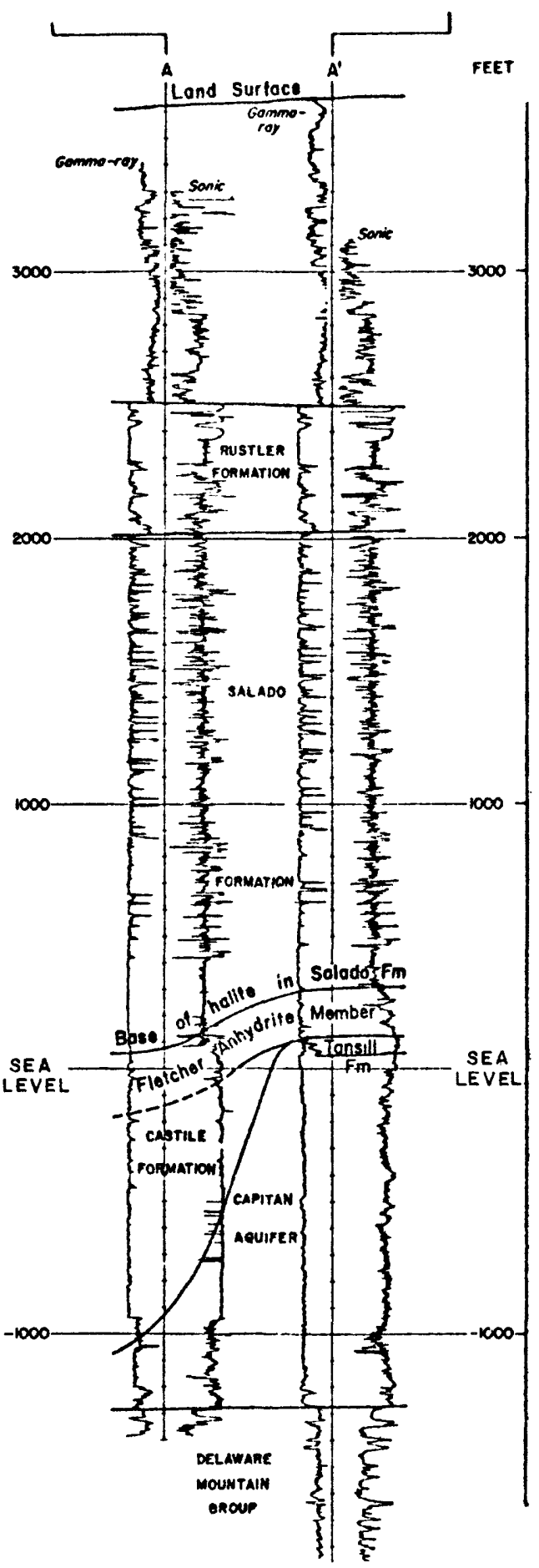

Modified from Hiss (1976)

Figure 10.--Steepness of the basinal edge of Capitan aquifer, Lea County, New Mexico 


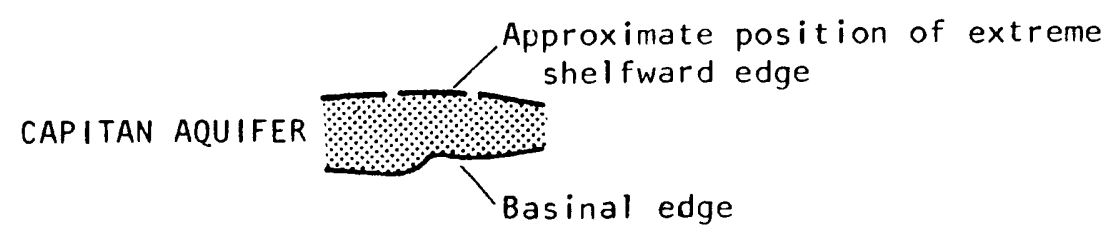

2800

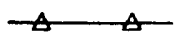

HEAD MEASURED IN THE CAPITAN AQUIFER AND SHELF AQUIFER SYSTEM WHERE HYDRAULIC CONNECTION BETWEEN THE TWO AQUIFERS IS RELATIVELY GOOD.

3200

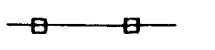

HEAD MEASURED IN DELAWARE MOUNTAIN GROUP WHERE THE HYDRAULIC CONNECTION WITH THE CAPITAN AQUIFER IS RELATIVELY POOR.

Contours are dashed wherever data are sparse or of doubtful reliability. Contour interval 100 feet. Datum is sea level.

The contours express a generalized regional head considered to be representative for the Delaware Mountain Group during 1960 to 1970. Similarly, contours in the Capitan aquifer are an interpretation of the head representative for the latter part of 1972 .

Considerable subjective judgment was used in contouring the data points. In general, two factors were weighed in considering each data point:

(1) The year in which the head was measured. This is important because prior fluid withdrawal from the oil and water fields causes a decline in head in nearby areas.

(2) The reliability of the data. In general, the data were ranked according to reliability in the following order: Fluid level in water wells, initial oil field bottom-hole pressures, and analys is of pressures from drill-stem tests.

\section{DATA POINT}

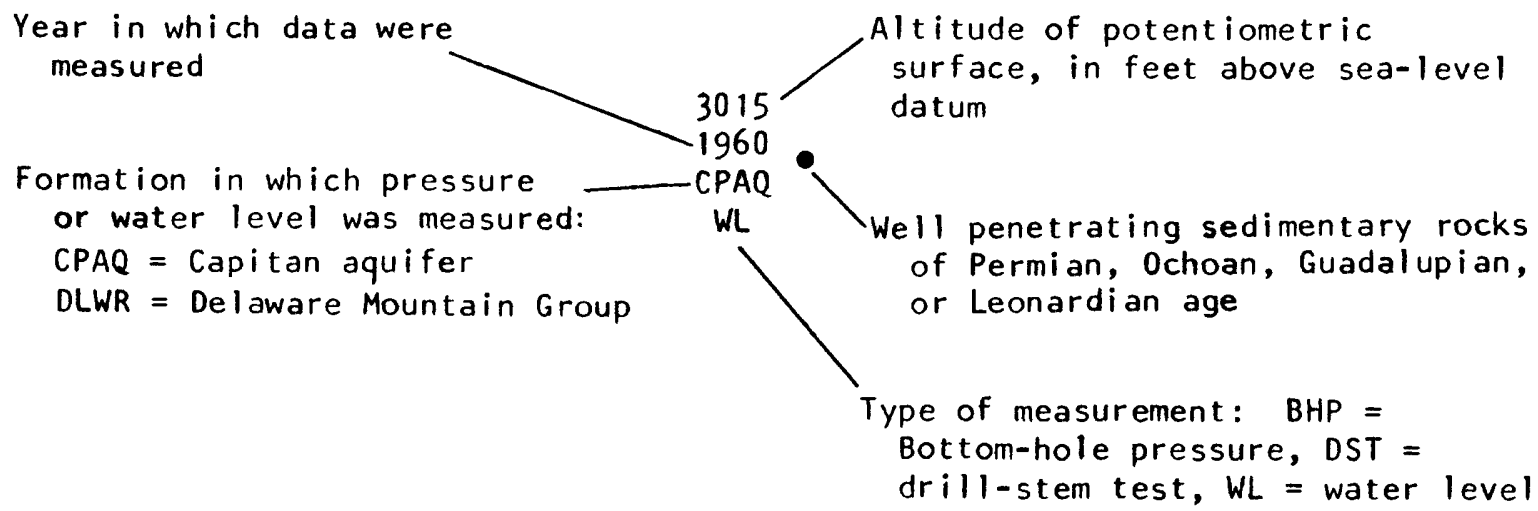

(Values of head are expressed as water with a density of 1.000 gram per cubic centimeter). 


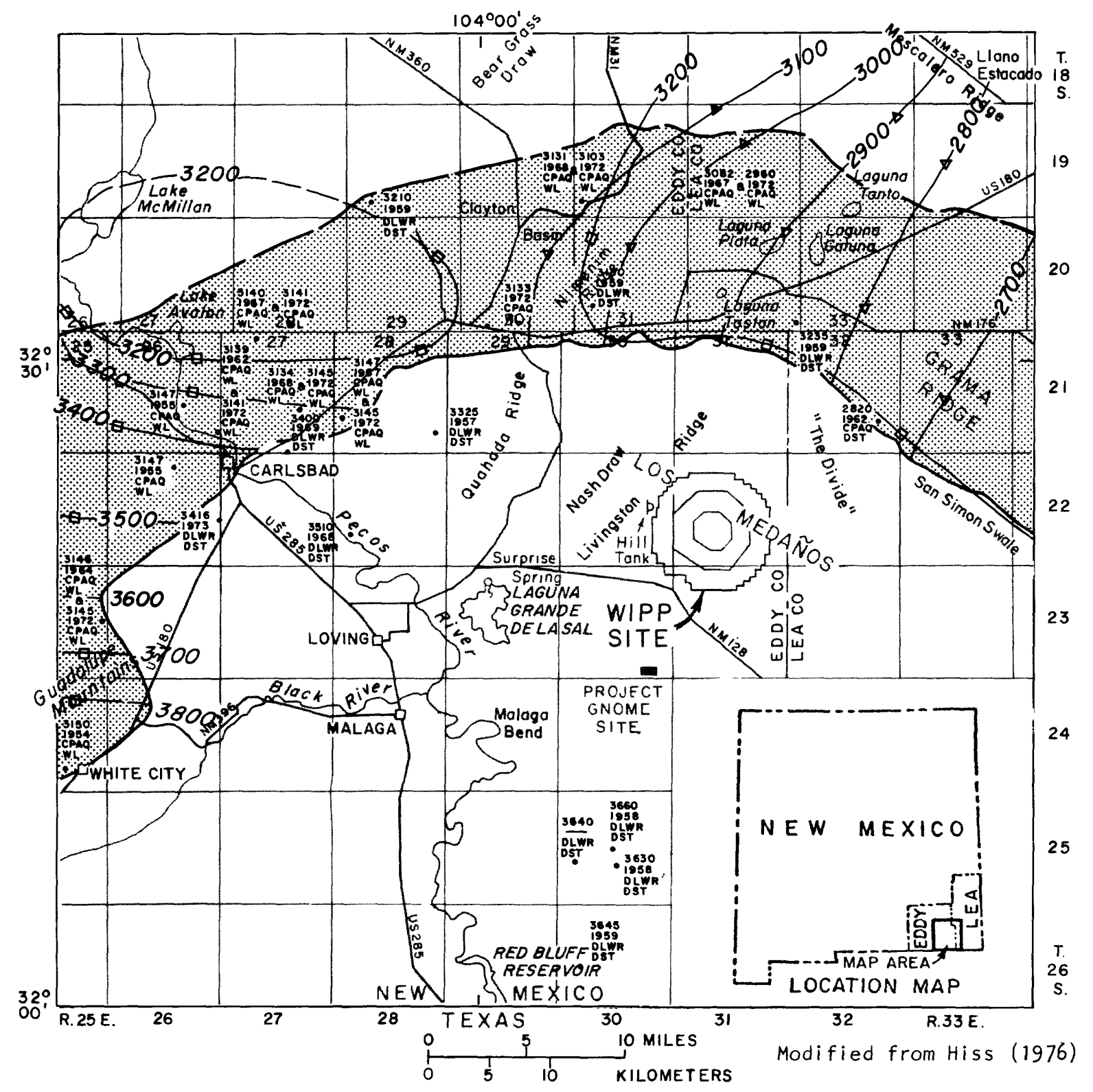

Figure 11.--Potentiometric surface of the Capitan aquifer in the vicinity of the proposed Waste Isolation Pilot Plant (WIPP) site 
tor the Capitan aquifer west of Carlsbad, Motts (1968, p. 295) indicates that yields of developed wells are from 1,000 to 4,000 gallons per minute. He also indicates from his studies that the occurrence and movement of water in the Capitan aquifer is controlled primarily by lithofacies changes. Permeabilities are greatest in coarser grained rather than finer grained detrital carbonates and in calcareous rather than dolomitic rocks. This association also is borne out by the work of Hiss.

Ground-water movement.--Water in the Capitan aquifer is under water-table conditions southwest of the Pecos River at Carlsbad, but to the north and east where the aquifer is entirely in the subsurface, artesian conditions prevail. Hiss (1976, p. 296) indicates that water entering the Capitan aquifer system in the Guadalupe Mountains moves eastward toward Carlsbad where most of the water discharges into the Pecos at Carlsbad Springs. He concludes that a deep, incised submarine canyon near the Eddy-Lea County line forms a hydraulic restriction that constrains the eastward movement of water from the vicinity of the Pecos River. Apparently there is little movement of water between the Pecos River and this restriction (fig. 11). However, east of this restriction the regional potentiometric surface, represented by the hydraulic head in the aquifer, has been changed significantly in response to withdrawal of both ground water and petroleum, especially during the last 50 years (Hiss, 1980, p. 294).

In summary, the Capitan aquifer system is unique hydrologically in that it forms a long narrow arcuate belt composed of very permeable rocks. Rocks with little permeability adjoining and underlying the Capitan aquifer control the movement of water. Lateral movement into the basin is prevented by the nearly impermeable anhydrites of the Castile Formation, while downward movement is controlled by the higher hydraulic head in the relatively impermeable Delaware Mountain Group. The shelf-aquifer system (Hiss, 1976) to the west and east of the Pecos River is interconnected with the Capitan aquifer, but the relatively lesser permeability of the shelf-aquifers (one to two orders of magniture less than that of the Capitan) restricts hydraulic connection.

Hydrochemistry.--There is an extensive discussion of the chemical composition of ground water associated with the Capitan aquifer in Hiss (1976, p. 208). In general, the water with relatively small chloride-ion concentrations is present in the Capitan aquifer throughout the region where the rocks have the greatest permeability; conversely, the water with the largest concentrations is present in rocks with the least permeability. The slightly saline water found in the Capitan aquifer and backreef rocks in southeastern New Mexico and western Texas probably is a result of selective displacement of the original brines by freshwater moving from the Glass and Guadalupe Mountains into formations with the regionally greatest transmissivity (Hiss, 1976, p. 210). Moderately saline waters are found in the Capitan aquifer in eastern Eddy County, especially in the area of the apparent hydraulic restriction near the Eddy-Lea County line. 


\section{Hydrology of the Castile Formation}

Geohydrologic characteristics.--The Castile Formation, consisting of thick anhydrite beds with thin interbeds of salt, lies between the Delaware Mountain Group and the overlying Salado Formation. It is almost completely confined within the Delaware Basin (Oriel, Myers, and Crosby, 1967), the only evaporite unit so restricted. Generally, the Castile averages between 1,500 and 1,850 feet in thickness except in west-central Ward County, Texas, southeast of the WIPP site where it reaches a maximum thickness of more than 2,100 feet (Adams, 1944, p. 1,604). Based on data from test holes drilled during site-characterization investigations at the WIPP site, the Castile is 1,518 feet thick in test hole AEC-7, 1,377 feet thick in test hole AEC-8, and 1,492 feet thick in test hole ERDA-10.

Extensive outcrops of the Castile are present in the western part of the Delaware Basin, in south-central Eddy County, New Mexico, and southward into Texas. The upper anhydrite beds have been altered to gypsum in the area of outcrop and contain solution features.

Very little hydraulic data are available from the Castile Formation. In the halite zones, the presence of water is restricted because the halite does not readily maintain primary porosity, solution channels, or open fractures. The same characteristics are inherent in the anhydrite, with the exception that if developed, fractures may remain open temporarily. Anhydrite hydrates to gypsum in the presence of slightly saline water. Hydration usually is accompanied by a 64-percent expansion in volume, which possibly could seal the fractures and prevent further water migration.

Drill-stem tests were conducted in the Castile Formation during drilling of test holes AEC-7, AEC-8, and ERDA-10 (Lambert and Mercer, 1977). The permeabilities of the anhydrites and salt interbeds were neglibible and in most tests could not be determined with conventional testing methods. However, based on the sensitivity of the test equipment, a conservative estimate for a hydraulic conductivity of the sections tested would be equal to or less than $1 \times 10^{-8}$ foot per day.

In most of the basin, the Castile evaporites act as a barrier or confining layer for water moving in the upper part of the Bell Canyon Formation of the Delaware Mountain Group. It has been suggested that movement of fluids upward from the Bell Canyon Formation through the Castile evaporites could develop a flow path for deep dissolution of the overlying Salado salts and subsequently develop dissolution features referred to as "breccia pipes" (Anderson, 1978, 1981). Anderson also suggested that the upward moving water would, as the concentration of dissolved salts increased, begin to move back downward due to a density differential. This concentrated brine, it is postulated, would move back down through the fracture system in the Castile to discharge into the Bell Canyon Formation. Anderson is concerned that these features could develop at or near the WIPP site. 
For this density-flow mechanism to work, an extensive fracture system would have to develop through the anhydrites of the Castile. Detailed studies of logs and cores from drill holes in the vicinity of the WIPP site have failed to identify such a fracture system or any other evidence that would indicate water has moved vertically through the evaporite sequence. In fact, to date (1983), no dissolution feature that has been identified within the basin has extended down as deep as the Castile Formation.

The hypothesis also requires that the upper part of the Bell Canyon Formation would be capable of transmitting these saturated brines away from the density-flow systems. The minimal permeability of sands in the Bell Canyon Formation probably would preclude removal of the volume of salt-bearing brines suggested by the hypothesis, even in the time intervals suggested.

Appreciable quantities of water have been reported in the Castile Formation along the western side of the Delaware Basin, but only in weathered zones near the outcrop. Anhydrites in these areas have been altered to gypsum, forming solution channels and cavities. These cavities are filled with silt and broken blocks of gypsum and act as reservoirs for ground water. Water is used locally for stock watering, but usually has large concentrations of dissolved solids.

Isolated pockets of brine and associated hydrogen sulfide have been penetrated by test holes of various oil companies and during site-characterization investigations at the WIPP site. These occurrences have been discussed in several reports resulting from these investigations (Griswold, 1980; Register, 1981). In general, these pressurized brines are present in a fractured anhydrite bed in the Castile. The brines, in all known instances, are associated with structural features, as determined by seismic methods and appear isolated and not part of an interconnected hydrologic system as determined by testing. Geochemical studies by Lambert (1978) show the Castile brine present in ERDA-6 test hole to be chemically and isotopically distinct from indigenous fluids in rocks above and below the Castile. Presently (1983), the Department of Energy is conducting a program that will test the brines extensively, so any further speculation here on the genesis of these brine pockets probably would be premature. The testing is being conducted on test holes ERDA- 6 and WIPP-12 and includes standard drill-stem tests and constant head-variable discharge flow tests.

Another dissolution feature that would require the extensive development of a hydrologic system in the Castile is the regional breccias that Anderson (1978) has proposed in the Castile Formation. These breccias, he postulated, are present in the subsurface at stratigraphic horizons corresponding to major halite beds; the proposed source of the water is the Capitan reef system. As discussed by Bachman (1980), a well-developed flow system would be required over an extended period of time for such extensive lateral dissolution to take place. During careful examination of geophysical logs, Bachman could not find a hydraulic system that was in the Castile Formation; 
in fact, he indicates that the halite beds have never been in close proximity with the Capitan reef system. Bachman proposes instead that the halites were deposited in individual and discrete sub-basins within the large Delaware Basin. The dissolution breccia zones described by Anderson would correspond to areas outside these sub-basins where halite was not deposited. To complete the circulation system, Anderson's (1981, p. 143) theory relies on fracture communication through the evaporites into the Bell Canyon Formation to drain off the brine; as discussed earlier, evidence for this flow mechanism is lacking.

Ground-water movement.--No regional flow system is present within the Castile Formation; the brine appears to occur in isolated pockets. Within the outcrop areas, some localized flow systems have developed in places where anhydrites have been hydrated to gypsum and localized recharge can occur through solution channels and cavities.

\section{Hydrology of the Salado Formation}

The Salado Formation predominantly consists of halite with minor beds of anhydrite, polyhalite, clastic rocks (sandstones and siltstones), and potash minerals. The massive halite beds within the Salado are the proposed host geologic medium for the WIPP facility.

The Salado is from 1,700 to 2,000 feet thick in most of the area underlying the WIPP site; it is 1,976 feet thick at test hole ERDA-9. Thicknesses may range from as little as 1,200 feet in the northeast to as much as 2,310 feet in deformationally thickened masses in the central part of the area (Jones, 1973, p. 11-18). Jones reports that in the western part of the study area variations in thickness of the Salado are complex and may be quite large. Their complexity and size are believed to reflect a combination of geologic factors involving: (1) Gradual thinning northward in response to changes in deposition patterns during the Ochoan; and (2) rapid thinning westward in response to increased dissolution.

West of the study area, where the Salado is near the surface, most of the halite has been removed by dissolution; in the northwest, where it at one time extended over the buried Guadalupian reef complex, it is absent. Dissolution in the Salado and overlying evaporites has been responsible for development of many shallow and surficial solution related features such as sinks and karst mounds. Within Nash Draw and possibly in Clayton Basin, solution has been removing halite from the uppermost part of the Salado Formation.

In the WIPP site area, a clay bed with broken gypsum and some fine-grained sandstone is present at the contact of the upper part of the Salado Formation with the overlying Rustler Formation. Jones (1973, p. 20) 
describes this clay as a subsurface saprolite (a residue concentrated through dissolution of clayey halite and other clay-bearing evaporites by percolating ground water). The residue thins to the east and grades into and intertongues with halite; to the west, it thickens and crops out along the Pecos River. Jones (1973, p. 20) indicates that the practice of assigning this unit to the Rustler Formation by many geologists should be discontinued because the residue is clearly part of the Salado Formation. From a geological standpoint, this unit may be more properly placed with the Salado Formation; however, as a hydrologic unit it is more easily included with the Rustler Formation. For a more detailed discussion of dissolution and time of dissolution, reference is made to reports by Jones (1973) and Bachman (1973; 1980).

The occurrence of water in the Salado Formation is restricted because the halite does not readily maintain primary porosity, solution channels, or open fractures. During drilling of test holes at the WIPP site and during investigations for potash mining operations, no evidence of circulating water was observed in the Salado.

The hydraulic conductivity of the halite in the Salado Formation has been measured in test hole AEC-7 (Peterson, Lagus, Broce, and Lie, 1981); these tests indicate that the halite has some measurable permeability. The tests were conducted using compressed-air injection into a zone of halite that was isolated by inflatable packers. The flow of air into the formation was measured, and the flow rates were interpreted in terms of formation permeabilities (intrinsic permeability as defined by Lohman, 1972) and porosities. The formation property values were determined based on the assumption that the halite bed could be modeled as an ideal unsaturated porous medium with a porosity of 0.001 . Stressing the assumptions they used and cautioning the indiscriminant use of the values obtained to model fluid particle velocity and fluid penetration distances, Peterson, Lagus, Rroce, and Lie (1981, p. 52) reported values of permeability (assuming a porosity of 0.001 and a measured well depth of 2,269 feet) of 12 and 21 microdarcies. This depth corresponds to the proposed depth for the WIPP facility. They conclude that the measured in-situ permeability of the halite may be greater than the true value because of formation discontinuities such as microfractures of the borehole wall created by drilling.

As previously discussed, the Salado Formation does not have active circulation of water; however, small pockets of brine have been penetrated during mining and drilling operations. Pockets of gas (nonflammable) and "air" have been penetrated at various depths during drilling of several stratigraphic test holes at the WIPP site. The air or gas was under sufficient pressure to cause unloading (blowouts) of the drilling fluid from the borehole. 


\section{Hydrology of the Rustler Formation}

The Rustler Formation in the WIPP site area has been divided into five members that are, in ascending order, an unnamed lower member, the Culebra Dolomite Member, an anhydrite called the Tamarisk Member (Vine, 1963) that is partly altered to gypsum, the Magenta Dolomite Member, and an upper anhydrite called the Forty-niner Member (Vine, 1963) (fig. 4). The Tamarisk and Forty-niner Members also contain halite in areas where dissolution has not been active. The Culebra and Magenta Dolomite Members at the WIPP site are the most significant units from a hydrologic standpoint and consequently were the most extensively studied.

The Culebra Dolomite Member consists of 25 to 30 feet of microcrystalline dolomite. It characteristically contains many small spherical cavities that range from 2 to 20 millimeters in diameter (fig. 12) and may be partly filled with secondary gypsum and calcite. Although many cavities are open, they do not appear to be interconnected except along fractures. Vine (1963, p. B-14) considers these cavities to be either a primary or a diagenetic phenomenon and not related to weathering in outcrops or secondary dissolution in the subsurface. In the subsurface, the Culebra is bounded above by anhydrites, which may contain gypsum as thick rinds along the contact with the dolomite. These gypsum rinds probably were formed by the movement of water through the dolomite. Underlying the Culebra there is either a clayey halite or a clayey residue, depending on whether the halite has undergone dissolution. Dissolution and removal of this halite bed is directly associated with subsidence, fracturing, and the occurrence of permeable zones in the Culebra. In the outcrops, the dolomite also may be locally brecciated or deformed by dissolution collapse.

The Magenta Dolomite Member (fig. 12) ranges in thickness from 20 to 30 feet and is characterized by alternating wavy laminae of silty dolomite and anhydrite (altered in places to gypsum). The dolomite is detrital in origin and is bounded above and below by anhydrite, which may be altered to gypsum along the contact with the dolomite.

A layer of residuum underlies the Rustler Formation in Nash Draw and geologically probably is part of the Salado Formation, but for hydrologic purposes it is considered part of the Rustler Formation. It is a unit composed of clay with crudely interlayered seams of brecciated gypsum and fine-grained sandstone (Jones, 1973, p. 20) (fig. 12). The clay is considered to be the result of dissolution of clayey halite and other evaporites in the upper part of the Salado. The clay, gypsum, and sandstone comprise a distinctive sequence referred to as the Rustler-Salado residuum. Because it is formed by dissolution, the residuum is quite variable in thickness, especially in Nash Draw. The unit thins eastward, grading into and intertonguing with the halite from which it originated. The residuum thickens westward and crops out at places along the Pecos River. 


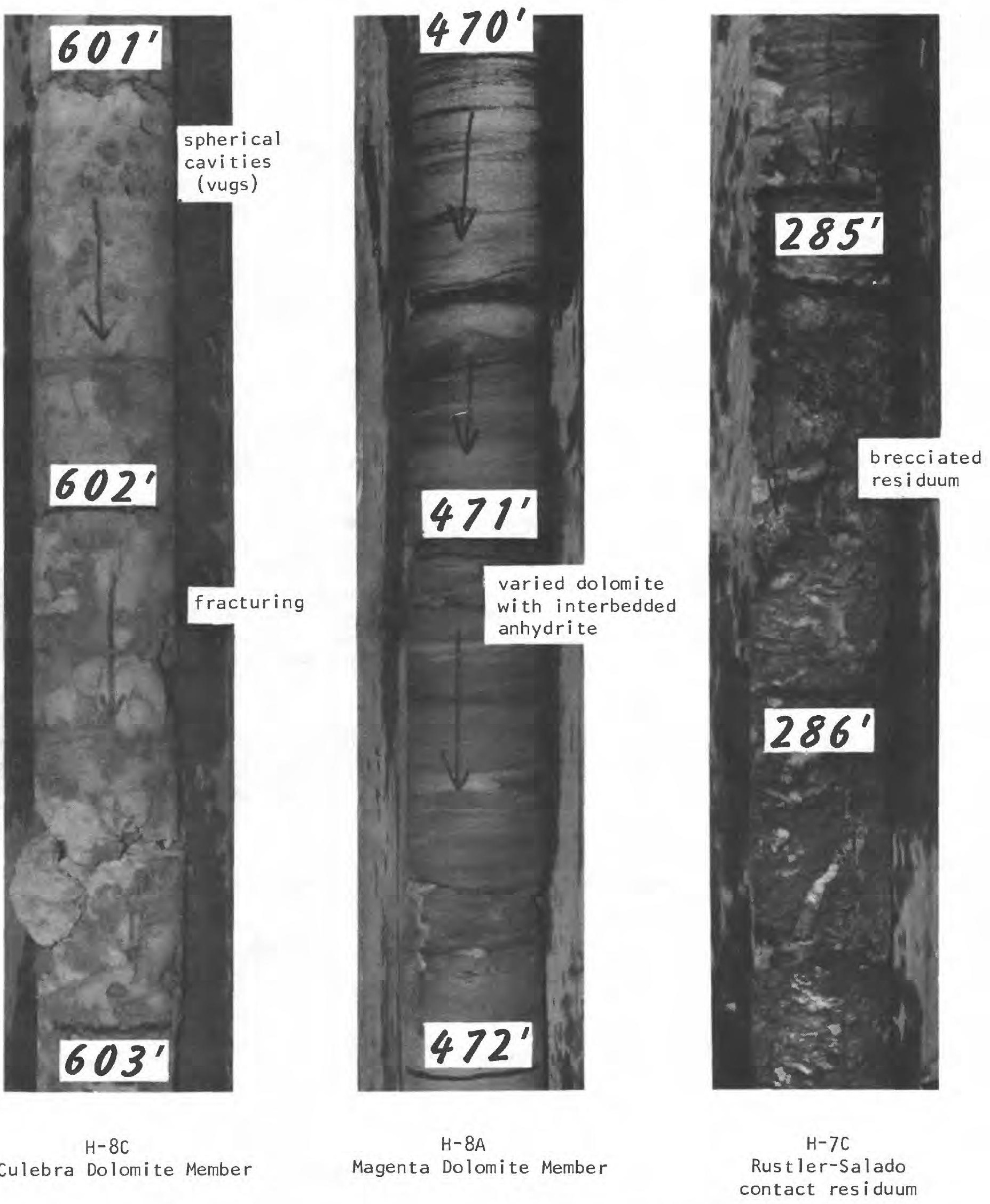

NOTE: Numbers on columns indicate feet below land surface.

Figure 12.--Core sections from hydrologic units of the Rustler and Salado Formations 
Exposures of the Rustler along the Pecos River and in Nash Draw are locally deformed, creating an irregular outcrop pattern. This deformation is caused by collapse of the harder, less soluble beds resulting from differential dissolution within the anhydrite, gypsum, and halite of the Rustler and the upper part of the Salado. Generally, the dolomite members are not as susceptible to dissolution as the evaporites; consequently, the dolomites are present throughout most of the area. The dolomites commonly are slumped and form draped features in outcrops along Nash Draw, while in other areas they may be broken into discontinuous blocks.

In some areas of Nash Draw, dissolution and erosion have been so extensive that the Magenta and Culebra Dolomite Members are virtually in contact, whereas in a normal stratigraphic sequence they would be separated by as much as 150 feet of halite beds and anhydrite. Other evidence of dissolution in the Rustler can be found throughout Nash Draw, as indicated by the development of sinkholes and other types of karst topography. Bachman (1981) presents a detailed discussion of these types of near-surface dissolution features. Nash Draw is separated by a low topographic divide from Clayton Basin to the north (fig. 1). A similar type of genesis, that of dissolution collapse accompanied by erosion, also is postulated for this feature.

There has been extensive dissolution of the Rustler Formation in the Malaga Bend area, causing the development of karst mounds (Bachman, 1980, p. 74). As described by Bachman, these mounds and other similar features appear to be controlled more by surficial dissolution in the Rustler Formation than deep-seated geologic processes.

Eastward from the Pecos River, especially east of Nash Draw where the Rustler Formation is covered and protected by the Dewey Lake Red Beds and younger rocks, structures are less chaotic and the Rustler attains a more regular character. In fact, detailed stratigraphy, lithology, and estimates of thickness are obtainable only from drill holes. The geologic section (fig. 5) east from Nash Draw identifies the lateral extent of the dissolution front in the Rustler. The structure of the rocks indicates a relatively simple homoclinal dip to the east.

The Rustler Formation ranges in thickness from 300 feet in test hole P-14 at the western edge of the WIPP site to more than 460 feet in P-18 near the southeastern edge of the site. The increase of 160 feet in thickness between $\mathrm{P}-14$ and $\mathrm{P}-18$ may provide an approximate measure of the minimum thickness of halite that has been removed by dissolution at test hole $\mathrm{P}-14$. The thickness of the Rustler Formation is 330 feet in the northeast part of the study area near test hole AEC-7. Jones (1973, p. 23) believes the difference in formation thickness between the southeast and northeast corners of the area may be depositional in origin because the formation is more thickly bedded in the southeast near test hole P-18. The theory for depositional variation in thickness is enhanced because evaluation of cores from test holes in these areas show no evidence of the dissolution residues 
common in other areas where the Rustler is thinner. The varying thicknesses shown by an isopach of the Rustler (fig. 13) represent both changes resulting from dissolution as well as those resulting from the depositional history. This becomes important when describing the hydrologic system because the areas of dissolution have an important bearing on the hydraulic properties of the Rustler Formation and associated rocks.

The hydrologic units of the Rustler Formation have been among the most extensively studied rocks at the WIPP site for two reasons: (1) They are the most productive; and (2) they directly overlie the Salado Formation and could provide a potential avenue for halite dissolution and consequently a means for transporting radionuclides from the proposed repository. Based on a previous study (Mercer and Orr, 1979), the most areally extensive water-bearing units have been identified as the the Culebra Dolomite Member, the Magenta Dolomite Member, and the Rustler-Salado contact residuum. Locally, water also may be found in some of the altered anhydrite units and at places in residue zones where halite has been leached. These occurrences usually are limited to Nash Draw and appear to be discontinous.

A discussion of the hydraulic characteristics logically leads to the division of the study area into two parts: (1) The Nash Draw area southward to Malaga Bend on the Pecos River; and (2) the WIPP site area proper, east of Nash Draw.

\section{EXPLANATION}

(FOR FIGURE 13)

PRESENCE OF HALITE BEDS

IN THE RUSTLER FORMATION

Above and below both Magenta

and Culebra Dolomite Members

Above and below Culebra Dolomi te

Member

Below Culebra Dolomite Member

None

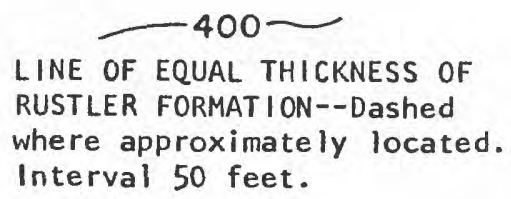

NOTE: See figure 5 for section showing top of halite in Rustler Formation.

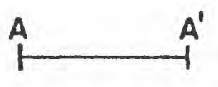

LINE OF GEOLOGIC SECTION

TEST HOLE

IDENTIFICATION OF TEST HOLES

$$
\begin{aligned}
& A=A E C \\
& E=E R D A \\
& H=\text { Hydrology } \\
& P=\text { Potash } \\
& W=\text { WIPP }
\end{aligned}
$$




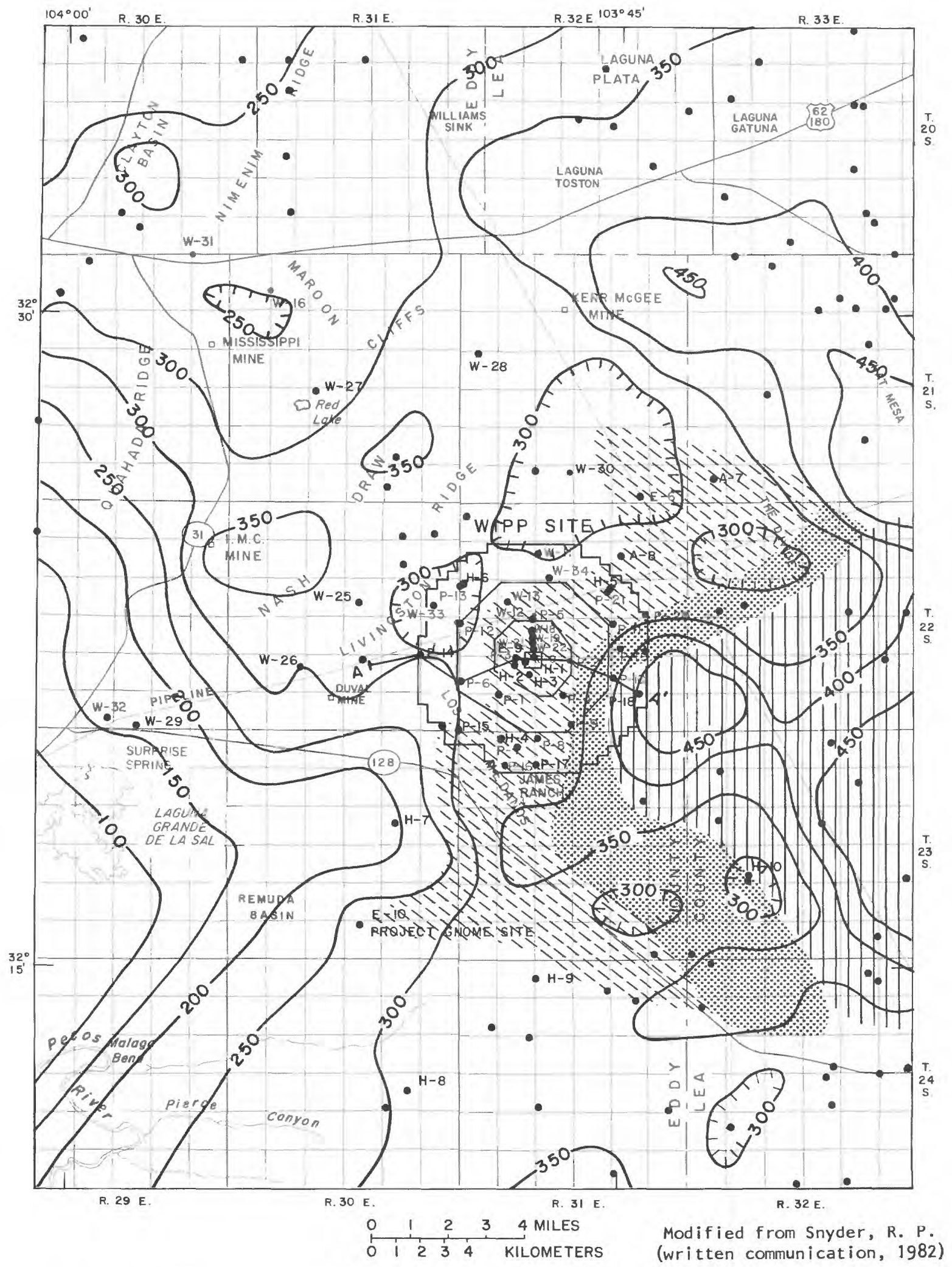

Figure 13.--Presence of halite beds and thickness of the Rustler Formation at and near the proposed Waste Isolation Pi lot Plant (WIPP) site 
The hydrologic flow system in Nash Draw is very complex and probably is controlled by geologic factors that caused development of the feature itself. Bachman (1980, p. 52) proposes the process of "solution-and-fill," which was discussed by Lee (1925) as the process responsible for the development of Nash Draw. Bachman describes the process whereby near-surface dissolution occurs as surface and ground water penetrates soluble rocks through joint systems and related fractures. The fractures are widened, developing cavities that either collapse (forming sinks) or subside (causing disruption of the more resistant beds). Collapse and subsidence commonly have been observed in Nash Draw. Arroyos actually disappear along fractures into caves in the gypsum.

Hydrology of the Rustler-Salado contact residuum--Brine in the Rustler-Salado contact residuum, immediately above the top of the salt in the vicinity of Nash Draw, was first described by Robinson and Lang (1938) and referred to as the "brine aquifer." Robinson and Lang (1938, p. 86) suggested that the structural conditions that caused the development of Nash Draw also might control the occurrence of the brine; thus, the "brine aquifer" boundary may coincide with the topographic surface expression of Nash Draw. Their studies show the brine to be concentrated along a strip 2 to 8 miles wide and about 26 miles long (fig. 14). Data from the test holes they drilled indicate that the residuum (containing the brine) ranges in thickness from 10 to 60 feet and averages about 24 feet. Hydraulic properties determined by Hale, Hughes, and Cox (1954, p. 22) were computed primarily for the area between Malaga Bend on the Pecos River and Laguna Grande de la Sal. They calculated a value of transmissivity of 8,000 feet squared per day and estimated the potentiometric gradient to be 1.4 feet per mile. In this area, the "brine aquifer" apparently is part of a continuous hydrologic system as evidenced by the coincident fluctuation of water levels in the test holes (as far away as Laguna Grande de la Sal) with pumping rates in irrigation wells along the Pecos River (Hale, Hughes, and Cox, 1954, p. 22).

In conjunction with the "brine aquifer" study, Robinson and Lang (1938) also made a study of Laguna Grande de la Sal and the area between it and Malaga Bend to determine if brine in the lake was a source of recharge to the system. They determined, at the time of their study, that the sources of the water in the lake were precipitation and surface drainage, ground-water inflow from units above the "brine aquifer", and effluent from the U.S. Borax and Chemical Company operation. Since that time, the U.S. Borax and Chemical Company plant has been closed; however, there still may be some inflow from mining activities that take place farther north in Nash Draw. Robinson and Lang identified several factors that led to their conclusion that the lake and underlying "brine aquifer" were not connected. These factors were: (1) Test holes drilled into the hydrologic units under the lake contained water with a different chemical composition and a much smaller chloride concentration; and (2) water levels in the fill indicated movement toward the lake and not away from it (in fact, the hydraulic heads were above the lake level in most test holes). Theis and Sayre (1942, p. 71) supported this conclusion because they found water levels in the lake to be high in winter and low in summer, whereas the hydraulic head in the "brine aquifer" is high in the irrigation season and low between seasons. 


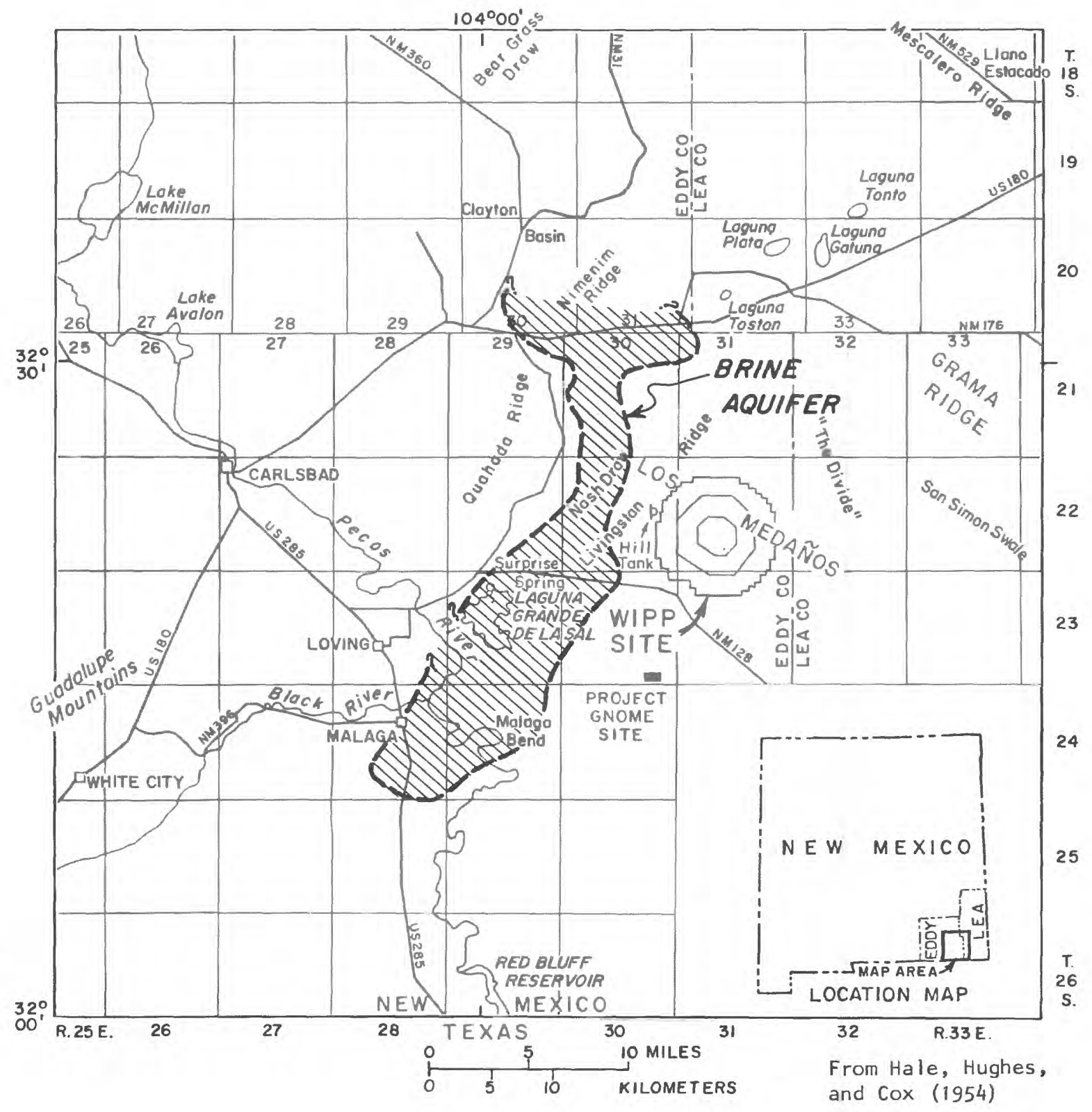

Figure 14.--Approximate areal extent of the "brine aquifer" near the proposed Waste Isolation Pilot Plant (WIPP) site 
Discharge of ground water into Laguna Grande de $1 \mathrm{a}$ Sal and probably into the fill is by the flow of springs and seeps, particularly along the northern end of the lake. The largest of these springs was identified by Robinson and Lang (1938, p. 95) and called Surprise Spring (SW $\frac{1}{4}$ NE $\frac{1}{4}$ SW $\frac{1}{4}$ sec. 4, T. 23 S., R. 29 E.), which was reported to discharge 115 to 125 gallons per minute. More recent WIPP studies indicate that the spring and accompanying seeps now discharge over such a broad area that accurate measurements of flow could not be made. This increase in the areal extent of the discharge area indicates an increase in discharge, probably resulting from the effects of effluent added by mining activities since Robinson and Lang's (1938) studies. The discharge of the spring probably comes from the cavernous gypsum of the Tamarisk Member of the Rustler Formation even though alternative sources, the Culebra Dolomite Member or the Rustler-Salado contact residuum, have been proposed. Data from more recent WIPP investigations indicate that the water chemistry and hydraulic-head information identify the source of the water to be something other than the Culebra or the residuum. Analyses of water samples from the Culebra Dolomite Member and Rustler-Salado contact residuum in test hole WIPP-29 (fig. la) near Surprise Spring indicate an increase in both sodium and chloride concentrations compared to Surprise Spring. However, there is 2.5 times more calcium in the water discharging from Surprise Spring. Additionally, hydraulic-head data from a potash test hole drilled for AMOCO in Laguna Grande de la Sal (T. 23 S., R. 29 E., sec. 4) show the Culebra to have a hydraulic head about 21 feet above the lake level, indicating a confined system although there may be some minor upward leakage. The Culebra was confined under about 40 feet of gypsum mud and flowed at a rate of approximately 20 gallons per minute when first penetrated during drilling activities. This evidence indicates that neither the water present in the Culebra Dolomite Member nor in the Rustler-Salado residuum are in good hydraulic connection with the brine from the spring that flows into Laguna Grande de la Sal. The most likely source of the brine is the Tamarisk Member.

In the northern one-half of Nash Draw, the approximate outline of the "brine aquifer" (Rustler-Salado contact residuum) as described by Robinson and Lang (1938) (fig. 14) has been supported by drilling associated with the WIPP geotechnical studies. These studies also indicate that the main differences in areal extent occur along the eastern side, where the boundary is very irregular and in places (test holes $\mathrm{P}-14$ and $\mathrm{H}-7$ ) extends farther east than previously indicated by Robinson and Lang.

Other differences from the earlier studies include the variability in thickness (table 1) of residuum present in test holes W-25 through W-29. These holes indicate thicknesses ranging from 11 feet in $W-26$ to 108 feet in W-29 in Nash Draw compared to 8 feet in test hole P-14 east of Nash Draw. The specific geohydrologic mechanism that has caused dissolution to be greater in one area than in another is not apparent, although a general increase in chloride concentration in water from the north to the south (table 2) may indicate the effects of movement down the natural hydraulic gradient. 
The historical data concerning hydraulic properties collected from the Rustler-Salado contact residuum are concentrated in the area from north of Laguna Grande de la Sal south to Malaga Bend. The data discussed in this report and collected for the WIPP regional hydrologic studies generally are from north and east of this area (fig. 1 ).

A potentiometric-surface map for the hydrologic unit of the Rustler-Salado contact residuum is based on data from both the Rustler-Salado contact residuum of Nash Draw and the brine at the contact of the Rustler and Salado Formations east of Nash Draw in the WIPP site area. The map data are adjusted for the effects of variations in water chemistry, which create density differences. As discussed under methods of investigation, the static heads represented by water levels in the wells were adjusted to a common density of 1.00 gram per cubic centimeter (freshwater equivalent, table 6). The potentiometric-surface map, representing freshwater equivalent heads, is shown in figure 15. The contours on this map represent the approximate values of static head and show the variance in gradients between Nash Draw and the area of the WIPP site. The average hydraulic gradient in Nash Draw is about 10 feet per mile; in contrast, at the WIPP site the average gradient is 39 feet per mile. This difference reflects the changes in transmissivity, which are as much as five orders of magnitude greater in Nash Draw. The transmissivity determined from aquifer tests in test holes completed in the Rustler-Salado contact residuum of Nash Draw ranges from $2 \times 10^{-4}$ foot squared per day at W-27 to 8 feet squared per day at W-29 (table 7). This is in contrast to the WIPP site proper, where transmissivities range from $3 \mathrm{x}$ $10^{-5}$ foot squared per day at test holes $\mathrm{P}-18$ and $\mathrm{H}-5 \mathrm{C}$ to $5 \times 10^{-2}$ foot squared per day at test hole P-14.

The potentiometric-surface map of the hydrologic unit of the Rustler-Salado contact residuum indicates that there are two areas of considerably different permeability. The zone of greater permeability is associated with the residuum (brine aquifer) of Nash Draw, where flow is primarily through associated fractures and the intergranular spaces of the clay and gypsum. In contrast, brine underlying the WIPP site east of Nash Draw occurs in a zone of minute permeability along the contact between the Salado Formation and the overlying Rustler Formation (bedding-plane flow).

As stated earlier, potentiometric-surface maps can be useful in showing the areal variations in hydraulic gradient from which a general trend in movement can be inferred. Inspection of the potentiometric-surface map for the hydrologic unit of the Rustler-Salado contact residuum indicates that the apparent ground-water flow is southwest across the WIPP site towards Nash Draw and then south-southwest down Nash Draw toward Malaga Bend (fig. 15).

Although caution should be used in making interpretations of the hydraulic-head distribution in the WIPP site for the hydrologic unit of the Rustler-Salado contact residuum, the inferred flow direction probably is valid. Static-head interpretations of the Rustler-Salado contact residuum within the area of the WIPP site are complicated by variations in water chemistry, and its effects on density, and by the great length of time required during testing to establish static conditions in test holes because of the minute permeabilities. 


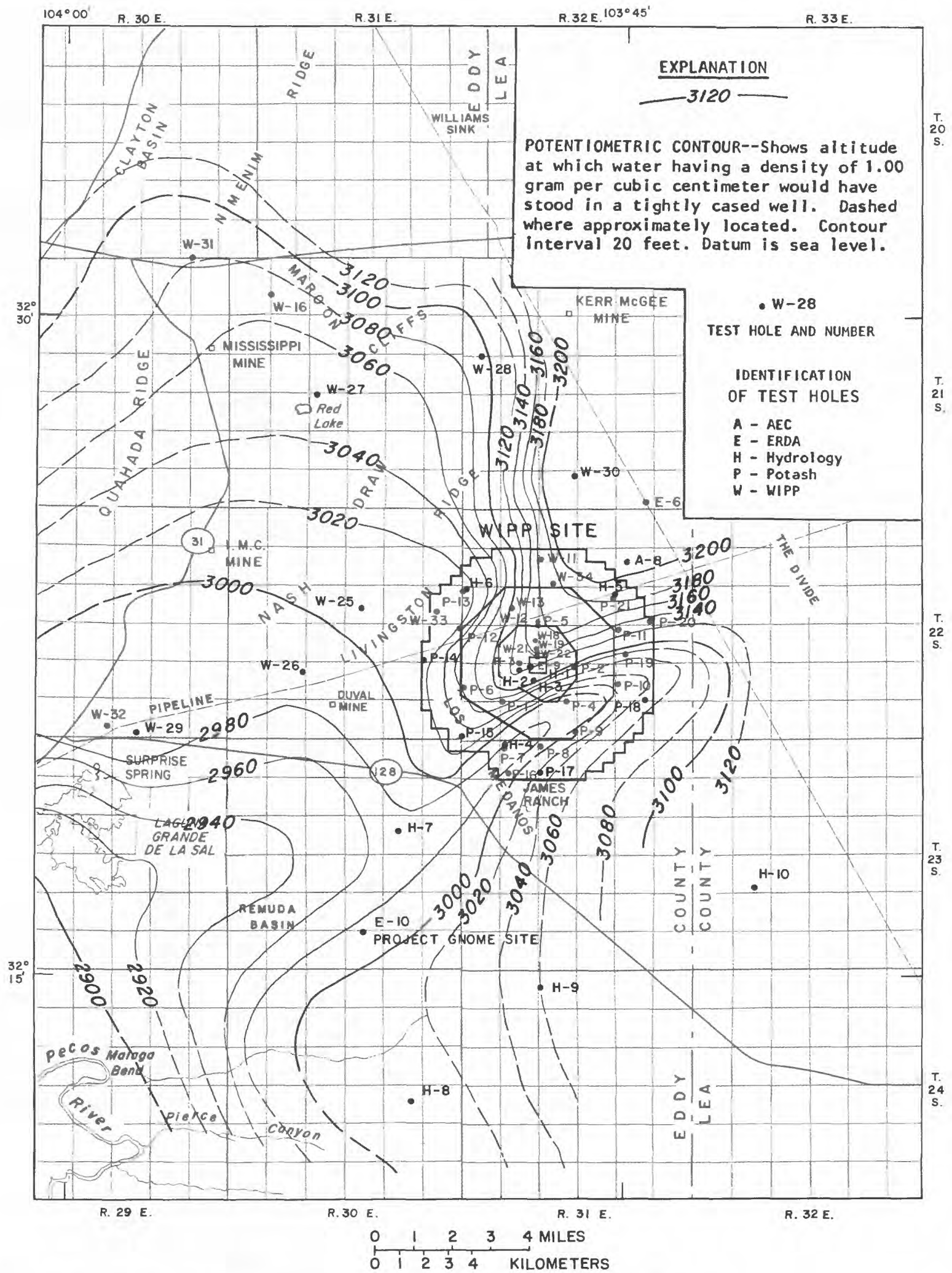

Figure 15.--Adjusted potentiometric surface of the Rustler-Salado contact residuum (1982) at and near the proposed Waste Isolation Pilot Plant (WIPP) site 
Calculations of the rate of movement of water in the Rustler-Salado contact residuum are complicated by the variations in permeabilities as well as in the hydraulic gradient. The rate of movement calculated by Hale and Clebsch (1958, p. 11) was 0.2 foot per day for the residuum (brine aquifer) south of Laguna Grande de la Sal. Assuming, as they did, an average effective porosity of 0.2 , an average hydraulic conductivity of 0.15 foot per day, and a hydraulic gradient of 10 feet per mile, the flow rate for the area from Maroon Cliffs to Laguna Grande de la Sal would be 0.002 foot per day, assuming that the residuum behaves as a uniform porous medium. Although the hydraulic characteristics of the Rustler-Salado contact residuum are variable, this rate probably is a conservative value. The rate of movement in the Rustler-Salado contact residuum at the WIPP site has not been determined because the hydraulic properties are extremely variable and because of the lack of a valid value for the effective porosity. Water-quality data, in particular the large concentrations of magnesium and potassium, indicate an extremely slow rate of movement with long periods of rock-water contact.

The area of recharge suggested by Lang (1938, p. 86) is in the area of Bear Grass Draw (T. 18 S., R. 30 E.), some 30 miles north of Malaga Bend. He suggests that water percolating into the ground may pass into the truncated lower part of the Rustler Formation and then migrate south and east into Nash Draw, gradually dissolving salt in the Salado Formation. Data from WIPP regional studies indicate that there is a hydraulic gradient from the north and that the Bear Grass Draw area may be a recharge area. There also is a possibility of some recharge occurring in Clayton Basin and Nash Draw.

Hale, Hughes, and Cox (1954, p. 23) believed the Rustler-Salado contact residuum discharges to the alluvium near Malaga Bend on the Pecos River. Because the confining beds in this area probably are fractured due to dissolution and collapse of the evaporites, the brine (under artesian head) moves up through these fractures into the overlying alluvium and then discharges into the Pecos River. Theis and Sayre (1942, p. 69) estimated that the discharge rate was about 200 gallons per minute and that in the Malaga Bend area about 342 tons of sodium chloride per day were discharged to the river, presumably all coming from the "brine aquifer."

Although the potentiometric-surface map (fig. 15) indicates a potentiometric high to the east of the WIPP site, there is not sufficient data to determine its origin. The possibility exists that there could be leakage from the overlying Culebra in this area; however, to accomplish this leakage the water would have to move through 80 feet of clay and silt and a 25-foot-thick anhydrite bed. Drilling at the WIPP site has not revealed any fractured anhydrite that could increase the vertical permeability, allowing water to move into the Rustler-Salado contact residuum, nor is there any indication that the water has altered the anhydrite to gypsum. Additionally, the hydraulic-head difference between the two hydrologic units (tables 6 and 9), about 90 feet in test hole $\mathrm{H}-2 \mathrm{c}$, coupled with the water-quality difference (table 2), would tend to indicate the zones are isolated and confined systems. The apparent high at test hole $\mathrm{H}-5$ could be due to the conversion of the dense brine to equivalent freshwater head. 
Evidence for very slow ground-water movement is found in the water quality, especially in the magnesium concentrations. Large magnesium concentrations appear to be indicative of an environment in which ground-water flow is extremely slow and there has been extensive interaction between the water and its host rock. Large concentrations of magnesium, ranging from 21,000 milligrams per liter in water from test hole $\mathrm{H}-6$ to 82,000 milligrams per liter in water from test hole $\mathrm{H}-5$, were present in most of the test wells in the eastern part of the WIPP site (table 2). Aquifer tests at these test holes were characterized by minute transmissivities (table 7). To the west, approaching the more developed part of the flow system of the Rustler-Salado contact residuum in Nash Draw, the magnesium concentrations decreased by 1 to 2 orders of magnitude (fig. 16). Magnesium concentrations of 1,200 milligrams per liter in water from test hole P-14 and 350 milligrams per liter in water from test hole P-15 may indicate the eastern boundary of the more developed Rustler-Salado flow system. Magnesium concentrations are as small as 430 milligrams per 1iter in water from test hole $\mathrm{H}-8$; other values range from 910 milligrams per liter in water from test hole $\mathrm{H}-7$ to 3,200 milligrams per liter in water from test hole $\mathrm{W}-25$. Based on the chemical analyses, the magnesium concentration in the brine could be used to outline the zone of active circulation (fig. 16).

Water at the Rustler-Salado contact, or in the residuum, contains the largest concentrations of dissolved solids in the WIPP area, ranging from 79,800 milligrams per liter in test hole $\mathrm{H}-7$ to 480,000 milligrams per liter in test hole $\mathrm{H}-1$. These waters are classified as brines. The areal distribution of major chemical constituents in water is shown in figure 16. The general chemical composition of the brine collected from the Rustler-Salado contact residuum also is listed in table 2; the major dissolved cations and anions are listed in table 8 and expressed in milligrams per liter, milliequivalents per liter, and percentage composition.

The dissolved-mineral constituents in the brine largely consist of sulfates and chlorides of calcium, magnesium, sodium, and potassium; the major constituents are sodium and chloride. Concentrations of the other major ions vary according to the spatial location of the sample and probably are directly related to the interaction of the brine and the host rocks and reflect residence time within the rocks. Residence time of the brine depends upon the transmissivity of the rock. For example, the presence of large concentrations of potassium and magnesium in water is correlated with minimal permeability and a relatively undeveloped flow system.

The dissolved-solids, magnesium, and potassium concentrations in the ground water increase from west to east in the WIPP area. An arbitrarily chosen line of equal concentration representing 2,000 milliequivalents per liter of potassium and magnesium combined (fig. 16) approximates a dividing line between zones of generally small concentrations to the west and rapidly increasing concentrations to the east. This same line, when viewed in terms of values of transmissivity, represents a division between areas of minute transmissivity (less than $1 \times 10^{-3}$ foot squared per day) and areas of greater 


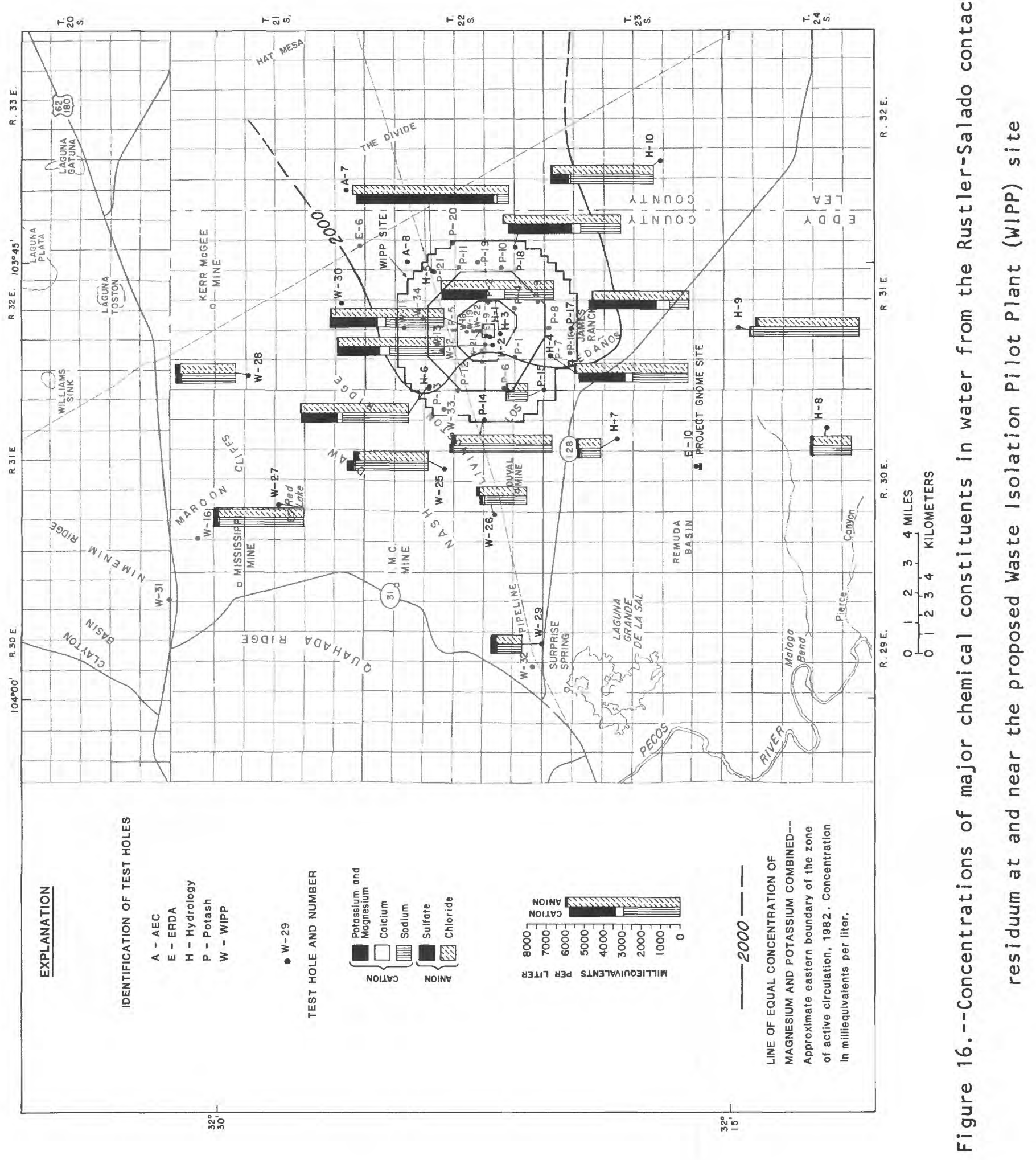


transmissivity (more than $1 \times 10^{-1}$ foot squared per day). This line indicates a division between the more developed flow system with accompanying evaporite dissolution and the minimally developed flow system in which ground-water movement, if any, is restricted to openings along bedding planes. A general lack of residuum to the east of this line, which indicates dissolution of the underlying Salado halite has not occurred, is further evidence that this area is not part of the more developed flow system.

Hydrology of Culebra Dolomite Member of the Rustler Formation--The Culebra Dolomite Member of the Rustler Formation ranges from 25 to 30 feet in thickness and is the most persistent and productive hydrologic unit in the area. In the WIPP site, the Culebra is a vuggy, finely crystalline dolomite that is present below the thick anhydrite of the Tamarisk Member, which in Nash Draw is mostly altered to gypsum. Water in the dolomite usually is present in fractures and is confined by the overlying gypsum or anhydrite and the underlying clay and anhydrite beds. The water may be under water-table conditions in the area south of Laguna Grande de la Sal where the Culebra has been subjected to solutional activity that has caused the confining beds to be extremely fractured and altered.

The structural character of the Culebra is related directly to the degree of dissolution. In Nash Draw, the Rustler Formation has undergone considerable deformation due to dissolution of parts of the evaporites and removal of halite from the underlying halite beds of the Salado. The effects of dissolution can be seen in some areas where large discontinuous blocks of Culebra are near the surface and have steep, erratic dips. In other areas, the Culebra is continuous and forms draped features. The Culebra crops out along the Pecos River in the Malaga Bend area. In those parts of the area east of Nash Draw where the Rustler is overlain by the Dewey Lake Red Beds and younger deposits, the dissolution effects have not been nearly as great and the structure of the Culebra is relatively regular.

In the WIPP site area there is a structural high clearly shown by contours drawn on the top of the Culebra Dolomite Member (Jones, Cooley and Bachman, 1973, p. 50). These contours outline an anticline in the northeastern part of T. 22 S., R. 32 E.; the anticline plunges to the southeast across the central part of the township. Excluding other minor structural irregularities, the overall gentle dip of the Culebra is to the east.

Hydraulic properties of the Culebra Dolomite Member determined by testing vary considerably from place to place and appear to be related to the size and number of fractures and openings. As previously mentioned, these fractures and openings are related to the degree of evaporite dissolution occurring either in the Rustler or the upper part of the underlying Salado Formation. The potentiometric-surface map, representing equivalent freshwater heads (table 9), is shown in figure 17. 


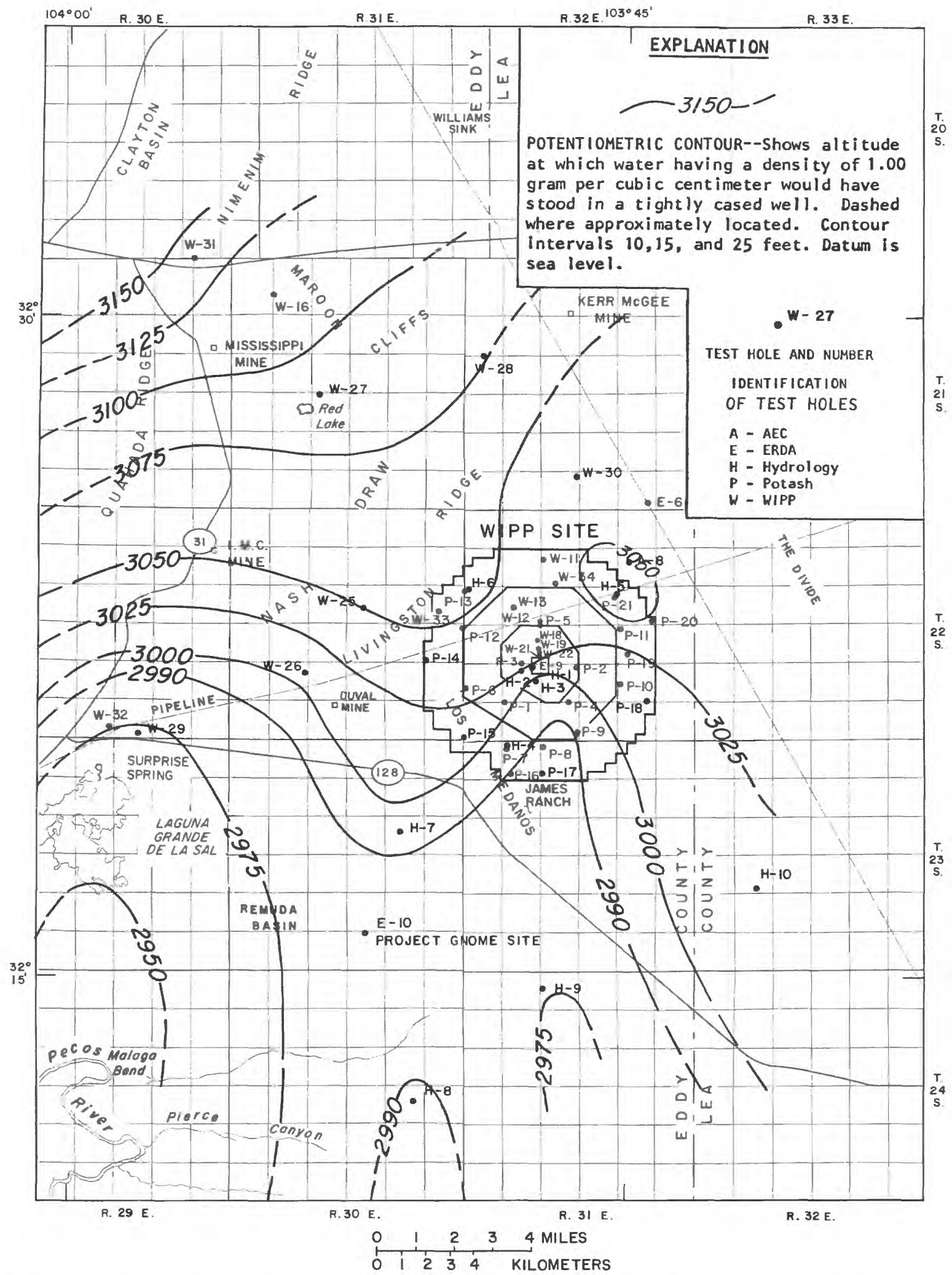

Figure 17.--Adjusted potentiometric surface of the Culebra Dolomite Member of the Rustler Formation (1982) at and near the proposed Waste Isolation Pilot Plant (WIPP) site 
The contours on the map indicate a variability in gradient as well as flow direction for different parts of the region. The gradient variability may reflect lateral variations in permeability within the Culebra Dolomite Member caused by local differences in the number and spacing of fractures. The flow direction may be variable. This variability may be caused by differences in fracture orientation in areas of greater permeability. The gradient in Nash Draw northeast of test hole W-29 is about 16 feet per mile, whereas, southwest of test hole $W-29$ it is 5 feet per mile. The gradients in the WIPP site area vary considerably, generally being about 7 feet per mile in the central part and 20 feet per mile in the northern and southern parts. The contours also indicate a potentiometric high near test hole $\mathrm{H}-5$, which may reflect the effects of the conversion of brine density to freshwater head. The broad area south of WIPP, where gradients appear to be extremely flat, may represent the transition from an area of fractured dolomite to that of a fractured and disrupted unit created by the extensive dissolution in the Nash Draw area.

Calculated values of transmissivity for the Culebra are based on the assumption of flow in porous media; because flow probably takes place along fractures, these values need to be used with care. It is believed, however, that the porous-media assumption should approximate flow conditions in the Culebra because the dolomite is thin and the fractures probably are closely spaced (fig. 18). Although the fracturing shown in figure 18 is associated with halite removal on the outcrop, areas of halite dissolution in the subsurface probably have similar fractures. Values of transmissivity for tests from 20 of the test holes drilled during WIYP investigations are included in table 7 .

Transmissivities calculated for the Culebra in Nash Draw range from 18 feet squared per day (Gonzalez, 1983) on the north end at test hole W-28 to 1,250 feet squared per day at test hole W-26 west of the WIPP site. These compare with a value of 535 feet squared per day calculated for the Culebra at the Project Gnome site (Cooper, 1962a, p. 37).

Hydraulic properties also were determined by laboratory tests of samples of the Culebra Dolomite Member taken from the Project Gnome shaft. One sample from a depth of 505 feet had a total porosity of 14.4 percent and an effective porosity of 7.8 percent, while a sample from 515 feet had a total porosity of 13.7 percent and effective porosity of 11.1 percent. The average effective porosity of 10 percent compares with the 12 percent value obtained by Grove and Beetem (1971) for a tracer test conducted on the Culebra in the same area.

Transmissivities calculated for the Culebra Dolomite Member in the WIPP site area range from $1 \times 10^{-3}$ foot squared per day at test hole $\mathrm{P}-18$ to 140 feet squared per day at test hole $\mathrm{P}-14$ and generally are less than 1 foot squared per day (table 7). Most of these values are several orders of magnitude less than those in Nash Draw. Smaller transmissivities probably indicate that less dissolution has occurred in the halite beds below the 


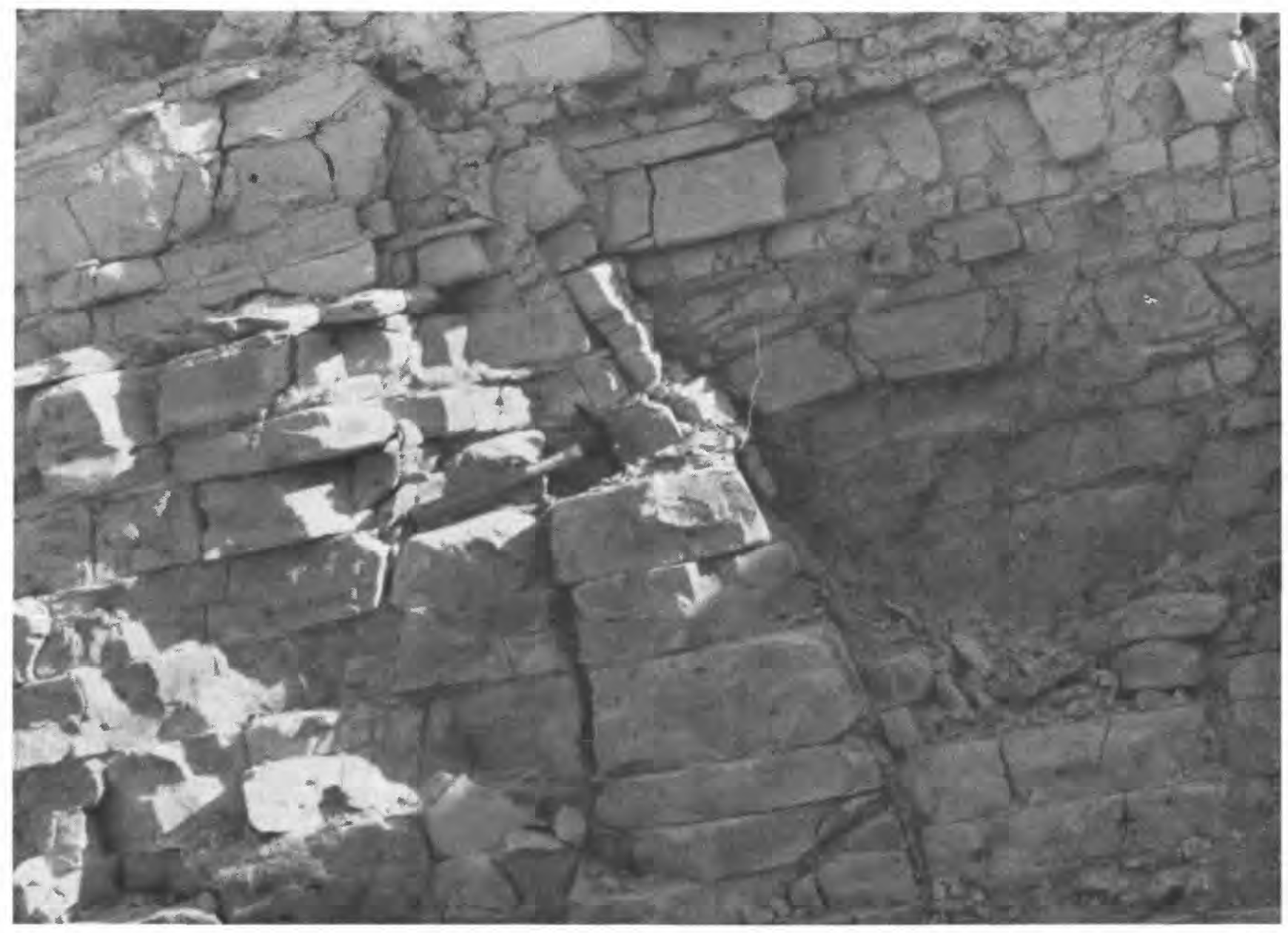

Figure 18.--Outcrop of Culebra Dolomite Member of the Rustler Formation where removal of underlying halite has caused fracturing. 
Culebra and in the upper part of the Salado Formation. Greater permeability has been noted where a silty residue is present immediately below the Culebra. This residue results from dissolution of a clayey halite bed below the Culebra, which caused subsidence and fracturing in the dolomite.

Transmissivity values calculated from tests in two test holes in the WIPP site area are much larger than the average; these test holes are $\mathrm{H}-6 \mathrm{~B}$, with a transmissivity of 73 feet squared per day, and P-14, with a transmissivity of 140 feet squared per day. Both of these test holes are on the western side of the WIPP site along Nash Draw. Geologic data from cores from these test holes indicate that the large transmissivity values may be related to localized dissolution in the Rustler Formation or upper part of the Salado Formation. Although not expressed topographically at the surface, an eastward subsurface extension of the geologic processes that formed Nash Draw may be the cause of the larger transmissivity. Approximately 8 feet of residuum was penetrated at the base of the Rustler in test hole P-14 and about 2 feet of residuum was penetrated in test hole $\mathrm{H}-6 \mathrm{~B}$. The transmissivity of the Rustler-Salado contact residuum in these test holes also is the largest in the WIPP site area. A similar occurrence was found south of the WIPP site in test hole $\mathrm{H}-8 \mathrm{~B}$ where the transmissivity was calculated to be 16 feet squared per day and in test hole $\mathrm{H}-9 \mathrm{~B}$ where the value was 231 feet squared per day (table 7). Because of these large values of transmissivity, it is possible, as in the case of test holes $\mathrm{H}-6 \mathrm{~B}$ and $\mathrm{P}-14$, that the geologic processes active in Nash Draw also may be occurring here.

When the distribution of halite beds in the Rustler Formation (fig. 13) is compared to the distribution of transmissivity across the WIPP site, it appears that dissolution of the halite in the lower part of the Rustler Formation is related to the permeability changes in the Culebra Dolomite Member. As these halite beds below the Culebra are dissolved, subsidence occurs, creating fractures in the dolomite that open up and allow movement of water. No fractures were noted in the overlying anhydrite in cores from most of the WIPP site test holes; thus, the Culebra is assumed to be effectively isolated from overlying water-producing zones east of the site. However, west of the site, fracturing may create some interconnection. It is generally accepted that the extensive dissolution in the Rustler Formation in Nash Draw is responsible for the permeability increases in the Culebra in that area.

The direction of ground-water movement in fractured rock, such as the Culebra Dolomite Member, is affected by directional differences in hydraulic conductivity (anisotropy); consequently, the regional direction of flow may have little or no relationship to the localized direction of flow indicated by the contours on the potentiometric-surface map. In Nash Draw the Culebra hydrologic unit is so extensively fractured that there may not be directional differences in hydraulic conductivity. Based on this premise and an inspection of the potentiometric-surface map, the flow trend in Nash Draw generally is southward toward Malaga Bend. Local flow paths in the area of the WIPP site, however, may not be as easy to determine. Because it was 
concluded that the ground-water flow in the Culebra at the WIPP site was in fractures, it became evident that further studies of the ground-water system were needed. Therefore, several hydrologic test holes penetrating the Culebra at the WIPP site were selected by project personnel for site-specific tracer and aquifer tests. These tests will determine the degree of anisotropy, effective porosity (for rate calculations), dispersivity, and transmissivity. The study is being conducted by Sandia National Laboratories and is in progress at the time of this report (1983); thus, any further evaluation of the flow system would be premature.

Based on water-quality data (table 2), hydraulic head differences (tables 7, 9, and 10), and analyses of cores taken from the hydrologic test holes in the WIPP site area, probably no effective vertical connection exists between the Culebra Dolomite Member and overlying hydrologic units. In test hole $\mathrm{H}-3$ near the site center, the stabilized hydraulic head in the Culebra is 155 feet lower than that in the overlying Magenta Dolomite Member. In the northwest part of the WIPP site at test hole $\mathrm{H}-6$, the hydraulic heads in the Culebra and Magenta are nearly the same; however, differences in the sodium and chloride concentrations in the water from the two units at test holes $\mathrm{H}-6 \mathrm{~A}$ and $\mathrm{H}-6 \mathrm{~B}$ indicate that vertical flow probably is very small. The dissolved-sodium concentration in water from the Culebra was 18,000 milligrams per liter compared to 1,100 milligrams per liter in the Magenta; the chloride concentration was 28,000 milligrams per liter in the Culebra and 1,200 milligrams per liter in the Magenta.

In test hole $W-25$ in the north part of Nash Draw, the static-head difference between the Culebra and Magenta is 4 feet; the sodium concentration was 5,100 milligrams per liter in the Culebra and 3,100 milligrams per liter in the Magenta, whereas the chloride concentration was 8,300 milligrams per liter in the Culebra and 5,600 milligrams per liter in the Magenta. These minimal hydraulic head differences and similar sodium and chloride concentrations, along with similar values of transmissivity (Culebra, 270 feet squared per day, and Magenta, 375 feet squared per day), suggest localized vertical interconnection in the north end of Nash Draw.

From test hole W-29 south to Malaga Bend, places probably exist where the Rustler-Salado contact residuum and Culebra may be interconnected (the Magenta has been stripped away by erosion); however, data are insufficient in this area to verify this possibility. A geochemical study to quantify the degree of interconnection currently (1983) is being conducted by Sandia Nationa1 Laboratories.

The Culebra was unsaturated in test hole ERDA-6 to the northeast of the site. Similar information has been reported for the area along Quahada Ridge west of Nash Draw. These data may identify permeability boundaries in the Culebra Dolomite to the west and northeast. 
The potentiometric-surface contours shown in figure 17 indicate a recharge area for the Culebra Dolomite to the north and northwest of Nash Draw. Like the hydrologic unit of the Rustler-Salado contact residuum, one potential area of recharge would be in the vicinity of Bear Grass Draw (T. 18 S., R. $30 \mathrm{E}$.), where the beds of the Rustler are truncated and downward percolating water could enter the Culebra. Although conclusive data are lacking, some recharge may be occurring in the area of Clayton Basin, where dissolution and collapse have disrupted beds in the Rustler Formation.

The discharge from the Culebra Dolomite Member probably is in the area south of Laguna Grande de la Sal near Malaga Bend, where the Culebra and overlying beds are significantly fractured. The ground water in this area probably is under water table or slightly confined conditions, with flow eventually discharging to the Pecos River. Some potential discharge to the Cenozoic deposits has been suggested to the east of Nash Draw (Tps. 25 and 26 S., Rs. 30 and 31 E.) (Cooper, 1962b, p. E152); however, if the discharge does occur, it is probably minimal. The currently (1983) available data are not sufficient in this area to draw any positive conclusions; therefore, future studies may be warranted.

Use of water from the Culebra Dolomite is quite limited because of the variability of yields and the marginal water quality. Where the water quality is acceptable, water from the Culebra is used for stock watering, but rarely for domestic purposes.

The dissolved solids in waters associated with the Culebra Dolomite Member range in concentration from 3,200 milligrams per liter at test hole $\mathrm{H}-8 \mathrm{~B}$ to 420,000 milligrams per liter at test hole $\mathrm{P}-18$; the large dissolved-solids concentration from test hole $W-29,239,000$ milligrams per liter, may be affected by effluent from the mining activities in Nash Draw. The water is classified as being slightly saline to briny.

The areal distribution of major chemical constituents in water from the Culebra is represented by bar graphs in figure 19. The general chemical composition of the water collected from the Culebra is 1isted in table 2. Major dissolved cations and anions, expressed in milligrams per liter, milliequivalents per liter, and percentage composition are presented in table 8.

The dissolved-mineral constituents in the water from the Culebra consist largely of sulfates and chlorides of calcium, magnesium, sodium, and potassium; the major constituents are sodium and chloride. The other predominant ions depend on the areal location of the water within the Culebra. The hydraulic characteristics of the Culebra have a bearing on the residence time of the water in the rocks; the residence time affects the concentration and type of dissolved constituents in the water. The potassium and magnesium concentrations are related to the transmissive characteristics of the rocks and the rate of circulation. 
The mineralization of water in the Culebra increases from west to east across the WIPP area; the combination of potassium and magnesium also increases (fig. 19). An arbitrarily chosen line of equal concentration representing 100 milliequivalents per liter of potassium and magnesium combined (fig. 19) approximates not only a dividing line between active and restricted circulation systems, but also approximately coincides with a line to the east of which halite is present in the Rustler Formation below the Culebra and to the west of which the halite beds have been removed by dissolution. As previously mentioned, the removal of these halite beds has caused an increase in the transmissivity of the dolomite. Although not as obvious in the Culebra as at the Rustler-Salado contact residuum, this line divides the area into zones where transmissivities generally are greater than 1 foot squared per day to the west and are generally less than 1 foot squared per day to the east. Even though this division is arbitrary, it does relate the water chemistry to the existing ground-water flow system.

Hydrology of Magenta Dolomite Member of the Rustler Formation--The Magenta Dolomite Member of the Rustler Formation is a persistent and distinctive clastic carbonate bed with thin laminae of anhydrite. The Magenta ranges in thickness from 20 to 30 feet and is present throughout most of the study area. The Magenta is the uppermost water-producing horizon in the Rustler Formation. Stratigraphically, it occurs between the thick anhydrite beds of the Tamarisk and Forty-niner Members (fig. 4). Water, when present, usually occurs in the thin silt beds or silty dolomite but also has been found along bedding planes between rock units and in fractures. The Magenta, where it was tested, was always under confined conditions except where it was extensively fractured and altered. In test holes $\mathrm{H}-7 \mathrm{~A}, \mathrm{~W}-26$, and $\mathrm{W}-28$, the dolomite was virtually unsaturated and was extensively fractured; the underlying anhydrite was fractured and in places altered to gypsum. The water formerly present in the Magenta in this area probably drained through the fractures into the underlying units.

The structure of the Magenta Dolomite, particularly in Nash Draw, is related to the presence or absence of evaporite dissolution. The Magenta in the northern and central parts of Nash Draw and along the eastern boundary is present in the subsurface as a relatively continuous bed; however, in the vicinity of test hole $\mathrm{W}-29$ and south to Malaga Bend, most of the Magenta has been stripped away by erosion. There are isolated blocks scattered throughout this area; the Magenta is present along the sides of karst sinks and in other collapsed features as breccia. The breccia mounds shown on Bachman's (1980) maps, particularly in T. 22 S., R. 29 E., sections 33 and 34, are excellent examples of this type of occurrence. These same features were described by Vine (1963, p. B41) as domal structures.

Outcrops of the Magenta are present along the western side of Nash Draw below Quahada Ridge. Although relatively continuous, they do show effects of weathering and are quite fractured, but are not saturated. A reasonable conclusion is that the dissolution responsible for the formation of Nash Draw fractured the Magenta and brecciated the underlying anhydrite, subsequently 


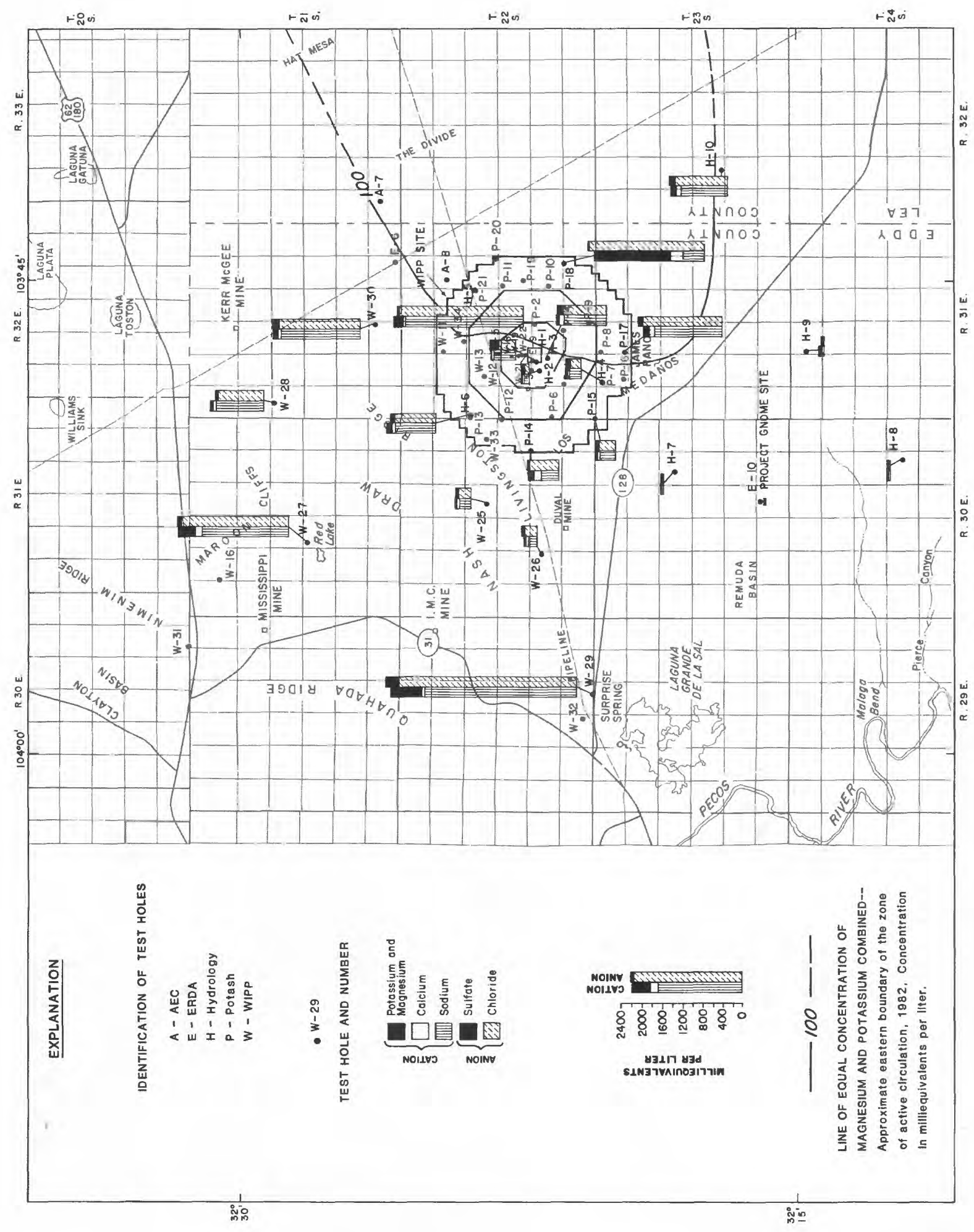

4

¿

ए

응

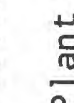

닌

$\frac{2}{3} \div$

든

탄

i

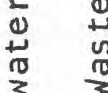

密 5 
draining the water into lower units. These fractures later were filled with secondary minerals. Evidence for this type of occurrence can be found in the cores taken from test holes in the area. An isolated occurrence of spring remnants was found along Livingston Ridge (Bachman, 1981, p. 5). These spring deposits are represented by a northeast-trending alignment of gypsite mounds (east $1 / 2$ of sec. 15, T. 22 S., R. 30 E.). The spring deposits are believed by Bachman to have resulted from the evaporation of sulfate-bearing water that had drained from the surface through fractures in the Rustler Formation, particularly in the vicinity of test hole W-33. An additional source for the water could be from subsurface drainage from the fractured Magenta.

To the east of Nash Draw, in the vicinity of and including the WIPP site, the Magenta generally dips gently to the east.

Although some flow along Livingston Ridge may be in fractures, the core samples and hydraulic tests at the WIPP site indicate the flow in the Magenta probably is within the silt beds and the silty dolomite, with some minor flow along bedding planes. Fracture flow probably is predominant in Nash Draw.

The potentiometric map (fig. 20), representing freshwater equivalent heads (table 10), indicates a flow system with some variability in permeability across the WIPP site. The contours show the gradient across this area to be 16 to 20 feet per mile on the eastern side and steepening to about 32 feet per mile along the western side near the boundary of Nash Draw. This steepening of gradient may reflect the drainage of ground water from the Magenta into lower units through the fractures associated with Nash Draw dissolution activity or may only reflect a decrease in permeability. The gradient in Nash Draw of about 13 feet per mile indicates a more uniform permeability than at the WIPP site. The Magenta, as an identifiable continuous bed, is not present below the central part of Nash Draw because erosion has removed all strata down to the Tamarisk Member of the Rustler.

Values of transmissivity for the Magenta Dolomite Member are included in table 7. In Nash Draw, these values range from 53 feet squared per day in test hole $W-27$ to 375 feet squared per day in test hole $W-25$; the large values probably are the result of increased permeability in fractured rock. The transmissivity calculated for test hole $W-25$ is the largest value recorded in the region for the Magenta; this test probably was affected by vertical leakage along fractures that connect with the underlying Culebra. The Magenta is unsaturated in test hole $\mathrm{W}-26$ as a consequence of fracturing caused by dissolution in lower beds. These fractures drained water from the unit; however, core analyses have indicated that these fractures were later filled with gypsum. Evaluation of the core from test hole W-28 indicated that bedding-plane partings and fractures were filled with gypsum, which would significantly decrease the permeability; vertical fracturing was not as evident as in test hole $W-26$. The Magenta also was unsaturated in test hole $\mathrm{H}-7 \mathrm{~A}$ at the margin of Nash Draw south of the WIPP site. The ground water at test hole $\mathrm{H}-7 \mathrm{~A}$ also probably drained into lower units, the subsequent 


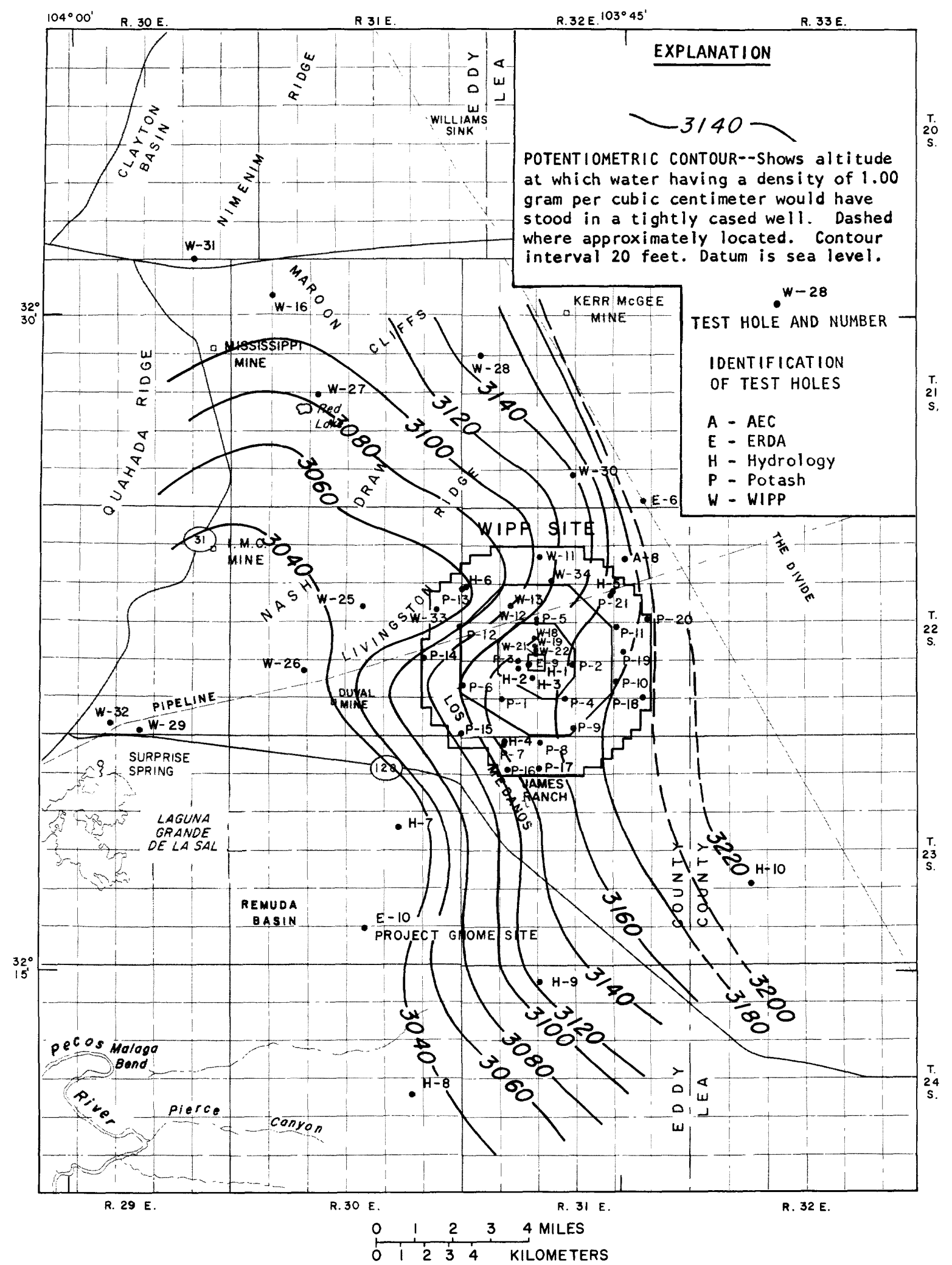

Figure 20.--Adjusted potentiometric surface of the Magenta Dolomite Member of the Rustler Formation (1982) at and near the proposed Waste Isolation Pilot Plant (WIPP) site 
alteration of the rocks considerably decreasing the vertical permeability. The core showed that this dolomite has been altered extensively to a partly cemented dolomite mud with the thin anhydrite beds that have been altered to gypsum. Like the other cores, secondary filling of gypsum sealed the fractures.

Hydraulic tests for the Magenta in the WIPP site area were conducted in seven test holes; transmissivity values from these tests ranged from $4 \times 10^{-3}$ foot squared per day in test hole $W-30$ to $3 \times 10^{-1}$ foot squared per day in test hole $\mathrm{H}-6 \mathrm{~A}$ (table 7). Hydraulic tests from the regional test holes south of the site showed that the transmissivity ranged from $6 \times 10^{-3}$ foot squared per day in test hole $\mathrm{H}-8 \mathrm{~A}$ to 1.0 foot squared per day in test hole H-9A (table 7).

The contours on the potentiometric-surface map for the Magenta Dolomite Member (fig. 20) indicate that water moves westward across the WIPP site towards Nash Draw, where it probably flows through fractures into lower units. In the northeast end of Nash Draw, the water flow generally is to the southwest, probably moving down through fractures into lower units in the central part of the draw.

The static heads and water-quality analyses indicate isolation of the Magenta from other units in the area east of Nash Draw and east and south of test hole $\mathrm{H}-6$. The hydraulic head differences between units in this area range from 115 feet in test hole $\mathrm{H}-2$ to 155 feet in test hole $\mathrm{H}-3$ (tables 6, 9, and 10). In Nash Draw, static-head differences between the Magenta and the Culebra vary from 8 feet in test hole $W-27$ and 4 feet in test hole W-25 to 72 feet in test hole $\mathrm{W}-28$; $\mathrm{W}-28$ probably is anomalous for Nash Draw. It is expected that some hydraulic connection does exist between zones in all the other Nash Draw test holes. The water quality in the Culebra and Magenta hydrologic units in test holes $W-25$ and $W-27$ (table 2) is very similar, indicating the possibility of hydraulic connection between these units.

Recharge to the Magenta probably takes place outside of the WIPP area, as it does for the other hydrologic units in the Rustler Formation. The most likely area is to the north in the vicinity of Bear Grass Draw and possibly in Clayton Basin. An inspection of the contours on the potentiometric-surface map indicates the possiblity of recharge to the east of the WIPP site. This apparent recharge is believed to be the effect of either the corrections made for variable water quality (and its density effect on the static-head calculations) or the locally steep gradients that result from decreased permeability to the east.

Discharge of water from the Magenta Dolomite in Nash Draw probably takes place in one of two ways, either by moving into lower units such as the Culebra or into cavernous zones in the Forty-niner Member, which has been altered by dissolution. The ultimate area of discharge is into the brecciated area in the Rustler near Malaga Bend and then into the Pecos River. 
The dissolved solids in water associated with the Magenta Dolomite Member of the Rustler Formation range in concentration from 5,460 milligrams per liter in test hole $\mathrm{H}-9 \mathrm{~A}$ to 270,000 milligrams per liter in test hole H-10A. The water is classified as being saline to briny (table 2). The areal distribution of major chemical constituents is represented by bar graphs in figure 21. The major dissolved cations and anions in water collected from the Magenta Dolomite are expressed in table 8 in milligrams per liter, milliequivalents per liter, and percentage composition.

As is characteristic of the other hydrologic units in the Rustler Formation, the dissolved-mineral constituents in the Magenta consist largely of sulfates and chlorides of calcium, potassium, magnesium, and sodium; the major constituents by percentage are sodium and chloride.

The relationship between the magnesium and potassium concentrations and the hydraulic properties of the hydrologic unit of the Magenta Dolomite Member is not as well defined as in other units, but does exist. The mineralization of the water and the combined concentrations of magnesium and potassium in the Magenta increase from the northwest to the southeast. The unusually large degree of mineralization in the water at test hole $W-27$ may be caused by a relatively well-developed hydraulic connection between the Magenta and other rock units that contain highly mineralized water.

The arbitrarily chosen line of equal concentration representing 50 milliequivalents per liter of potassium and magnesium combined (fig. 21) indicates a division between a relatively well-developed flow system and one in which circulation is restricted. Although not as well defined as in the case of the Culebra, the line does indicate the area in which halite has been removed from below the Magenta (halite removed to the northwest, halite present to the southeast). The effects of the fracturing resulting from the halite removal on the hydraulic properties of the Magenta are not as pronounced as in the Culebra.

\section{Hydrology of the Dewey Lake Red Beds}

Geohydrologic characteristics-The Dewey Lake Red Beds comprise the youngest rocks in the Ochoan sequence at the WIPP site and mark an abrupt change in the depositional environment. This change was from predominantly evaporitic deposits in the Rustler to a deltaic sequence of alternating thin, even beds of siltstone and mudstone with lenticular interbeds of fine-grained sandstone. Nearly all the siltstone and mudstone are veined with selenite gypsum in the cores. The Dewey Lake dips gently eastward, increasing in thickness from 350 feet in test hole P-14 to 541 feet in test hole P-18 (fig. 5). The Dewey Lake Red Beds are separated from the overlying Triassic Santa Rosa Sandstone by an erosional unconformity east of test hole ERDA-9; west to Livingston Ridge (along Nash Draw), the Dewey Lake is overlain by 


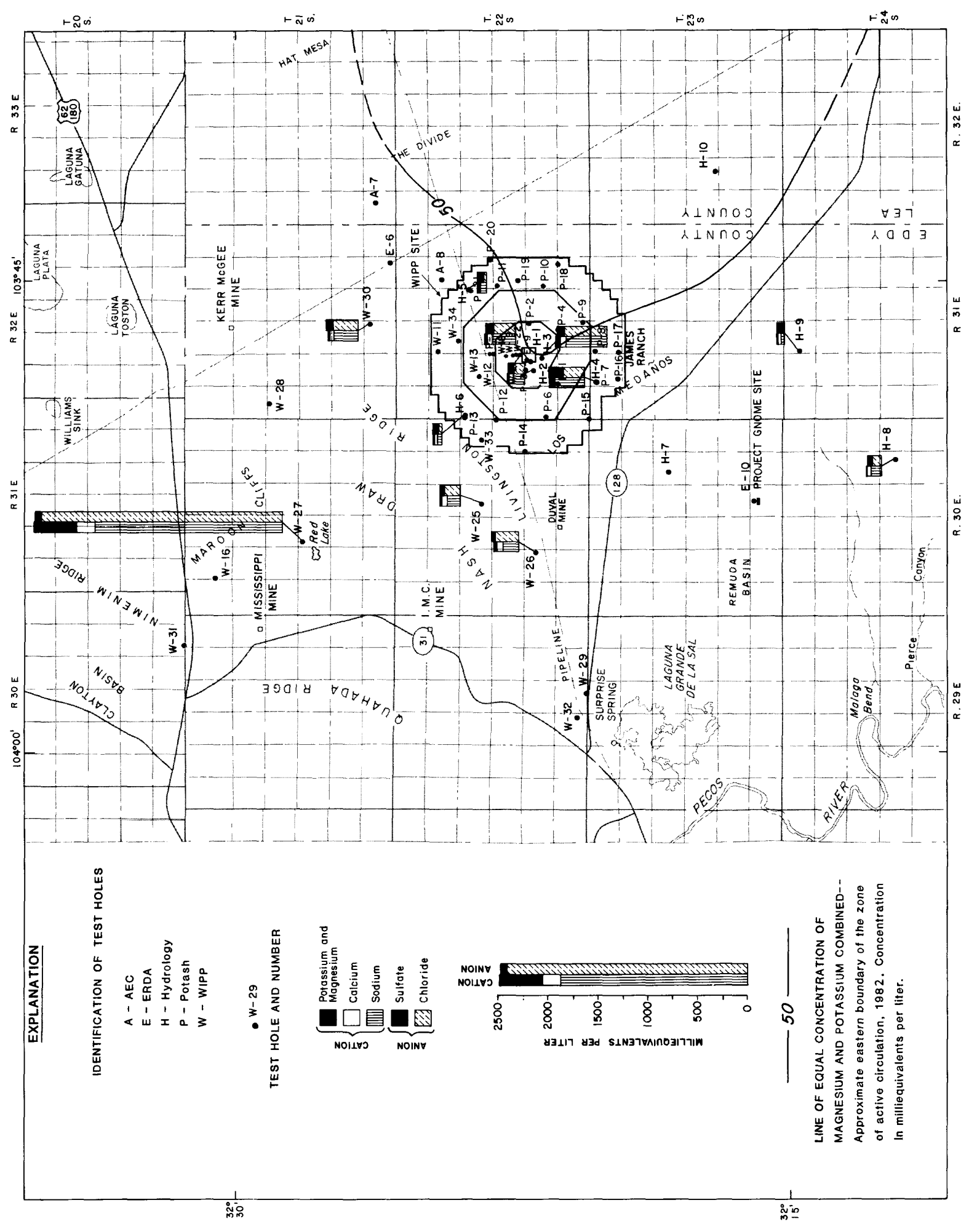

4

㐫

趸

$\stackrel{2}{3}$

ह

응 $\frac{1}{0}$

它

동 음

品

更

采

든 온

$\begin{array}{ll}1 & 0 \\ 4 & 0 \\ 0 & \frac{1}{3}\end{array}$

(1)

3

7

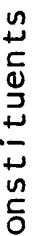

ก

는

$\stackrel{\Phi}{ \pm}$

$\frac{1}{8}$

ช 0

๕ิ

4

$\frac{0}{0}$

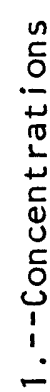

i

选 
the Gatuña Formation and other Cenozoic deposits. The thickness of the formation decreases to the west where it was thinned by post-Permian erosion. The Dewey Lake in Nash Draw has been almost completely removed, in places being present only in sinks and other collapse features. The Dewey Lake crops out in low bluffs along the north and east sides of Nash Draw. Because of its characteristically minimal permeability, it does not contain significant quantities of ground water.

Drilling during areal geohydrologic evaluation did not identify a continuous zone of saturation within the Dewey Lake Red Beds; however, localized zones of permeability were detected. In the geologic test holes, the presence of these zones was indicated by minor losses of circulation during drilling. Detailed data collected during air-drilling of the hydrologic test holes (Mercer and Orr, 1979) did identify minor zones of saturation, particularly in several of the thin lenticular sands in the upper part of the Dewey Lake at test holes $\mathrm{H}-1, \mathrm{H}-2$, and $\mathrm{H}-3$.

In most instances, the only indication of ground water was the presence of moist cuttings. In test hole $\mathrm{H}-2 \mathrm{C}$, an attempt was made to test the moist sands present at a depth of 185 feet. After monitoring the zone for 5 hours, very little water had entered the hole and the test was stopped (Mercer and Orr, 1979, p. 58). Geologic data from the wells at the WIPP site indicate the sands to be lenticular, pinching out laterally. Where water is present, it probably is perched or semiperched, and its occurrence is very localized, probably depending to a great extent on locally favorable conditions for recharge.

The Dewey Lake has not normally been found to yield water to wells; however, several wells used for domestic and stock purposes at the James Ranch could possibly be completed in one of these lenticular sands. These wells in T. $23 \mathrm{~S} .$, R. $31 \mathrm{E}$, , sections 6 and 7, range in depth from 94 to 212 feet (Cooper and Glanzman 1971, p. A16). These wells have either saline water or small yields; geologic data indicate they are completed in the upper part of the Dewey Lake. Just east of this area there is an extensive, thick, active area of sand dunes, which could be a recharge area for these water-bearing sand units. No other wells in the area are known to produce water from the Dewey Lake.

Ground-water movement--Recharge of sand units in the Dewey Lake could result from localized conditions, as in the James Ranch area, or could occur by downward percolation of water through fractures or along bedding planes in the mudstone and siltstone. Discharge towards deeper zones through existing fractures or through dissolution of the gypsum veinlets is minor. The Dewey Lake is a protective cover that retards dissolution of evaporites in the Rustler Formation. If the ground water penetrated to the top of the Rustler Formation in the WIPP site, then the upper anhydrite should be altered to gypsum. Cores and geophysical logs do not indicate that this alteration is present except where the Dewey Lake is thin or absent. Ground-water movement within the Dewey Lake is restricted because of the perched character of the water in these lenticular sands. 


\section{Hydrology of the Upper Triassic Santa Rosa Sandstone}

Geohydrologic characteristics--The Santa Rosa Sandstone, present only in the eastern one-half of the WIPP site, overlies the Dewey Lake Red Beds (fig. 5). The Santa Rosa crops out at the north end and along the east side of Nash Draw. The Santa Rosa consists of a fine- to coarse-grained sandstone with interbeds of siltstone and mudstone; it ranges in thickness from a featheredge west of test hole ERDA-9 to 176 feet in test hole H-10. To the west of test hole ERDA-9, the Santa Rosa has been removed by erosion. Throughout most of the area, the Santa Rosa is covered by surficial Cenozoic deposits; however, in test hole $\mathrm{H}-10$, the sandstone is overlain by 392 feet of unsaturated Triassic Chinle Formation.

Although the Santa Rosa Sandstone is reported to be a principal aquifer in southwestern Lea County (Nicholson and Clebsch, 1961, p. 57), water was only present in the lower part of the formation in test hole $\mathrm{H}-5$. Air drilling was used to identify the presence of water. Although an attempt was made to test the zone, the only reliable data collected were from a water sample from which the chemical composition of the water was determined (table 2). The water was under water-table conditions and was present in a sandstone immediately overlying the Dewey Lake Red Beds. In test hole $\mathrm{H}-10$, the Santa Rosa was monitored during air-drilling and no indication of water was found. Several wells east of the WIPP site have been reported to obtain water from the Santa Rosa, but yields are reported to be small. According to geophysical logs, a well in T. $22 \mathrm{~S} ., \mathrm{R}_{\text {. }} 31 \mathrm{E} ., \mathrm{sec} .15$, just west of test hole H-5, was completed in the lower part of the Santa Rosa; however, well yields were reported to be very small.

Ground-water movement--The Santa Rosa probably is recharged by precipitation in the area where it is overlain by permeable Cenozoic deposits, especially in the eastern part of the WIPP site. The water moves downward until it is impeded by the relatively impermeable Dewey Lake Red Beds and then probably moves down the structual dip to the east. Where the Santa Rosa lies beneath the Chinle Formation, the water that is found in the Santa Rosa probably is under confined conditions. Small quantities of water probably discharge locally into the Dewey Lake through fractures and along bedding planes. Nicholson and Clebsch (1961, p. 57) believe that further to the east ground-water movement in the Santa Rosa is controlled by the collapse features of San Simon Swale. Nicholson and Clebsch show the pressure gradients to be toward the swale. 


\section{Hydrology of Tertiary and Quaternary Rocks}

Of the Tertiary and Quaternary rocks in the vicinity of the WIPP site, the Gatuña Formation of Pleistocene age and the playa deposits and alluvium of Holocene age are the only units that contain water. The volume of water in these sediments is quite small.

The Ogallala Formation of Miocene age is an aquifer north and east of the area; however, along The Divide near the WIPP site, it occurs in isolated outliers no more than 60 feet thick. These outliers generally are unsaturated.

The Mescalero caliche of Holocene age is a well-lithified calcium carbonate and functions more as a barrier to downward movement of water than as a ground-water reservoir. The Mescalero caliche covers most of the WIPP site area although it is not present in Nash Draw.

Gatuña Formation--The Gatuña Formation is present as discontinuous bolson-type deposits. In the WIPP site area, the Gatuna is represented by several tens of feet of poorly sorted silt, clay, and sandstone that may grade downward into conglomeratic sandstone containing clasts of siltstone and sandstone (Jones, 1978, p. 10). Of the post-Tertiary rocks in the study area, the Gatuña Formation is the thickest and least extensive; characteristic of its erratic distribution, the Gatuña is absent in some test holes and is more than 100 feet thick in others (143 feet in test hole $\mathrm{H}-8$, for example). Where it does occur at the WIPP site, it is generally no thicker than 46 feet (table 1). In most areas, the Gatuña is overlain by the Mescalero caliche.

Because of its erratic distribution, there is no known continuous saturated zone within the Gatuña Formation. Although Cooper and Glanzman (1971, p. A10) have reported that there were some limited occurrences of water in the Gatuña in the Project Gnome area, no water was found during the drilling at the WIPP site. If water is present in places, it probably would be perched in sandstone lenses overlying the less permeable Dewey Lake Red Beds.

During building-foundation tests in the central part of the WIPP site, 30 exploration holes were drilled to test the hydraulic conductivity of the Gatuña. Packer-permeability tests in these holes were conducted using injected water; these tests indicated that the hydraulic conductivity generally ranged from less than $3 \times 10^{-3}$ to 1.9 feet per day; one value of 5.1 feet per day was noted. (Register, 1981, p. 8). No indication of water was found in any of these holes. 
Water movement in the Gatuña apparently is restricted by the discontinuous "perched" zones and the sporadic occurrence of the unit. Recharge to the Gatuña probably is by local downward percolation of precipitation, especially in areas where rain water is ponded on the surface. This recharge probably is hindered by the caliche cover in the WIPP site area. Most water in the Gatuña probably is transpired by phreatophytes although some water may percolate downward into lower zones, particularly in the eastern part of the study area where the Gatuña overlies the Triassic Santa Rosa Sandstone.

Surficial deposits and alluvium--In the main part of the study area there are no through-flowing streams; the surficial deposits are composed of locally derived material deposited by sheet wash or by discontinuous arroyos. These surficial deposits are present almost everywhere in the region and usually are only a veneer over the underlying bedrock. Exceptions exist where deposits are concentrated in depressions created by dissolution of underlying rocks.

The only stream-deposited alluvium in areas near the WIPP site is along the Pecos River, mostly along the west side of the river north of Malaga Bend. This alluvium is composed of sand, gravel, silt, and clay and is as much as 200 feet thick. One of the most notable features of the alluvium is its large variation in thickness, which probably is caused by the alluvium filling the depressions created by dissolution of underlying rocks (Hale, Hughes, and Cox, 1954, p. 20). South of Malaga Bend, the alluvium is present in isolated patches, which may be as much as 150 feet thick but generally average about 50 to 75 feet thick.

Playas within the study area are reported to contain alluvium and eolian sands that have been reworked by shallow lake waters (Vine, 1963, p. B35). Playa deposits consist of silt, sand, and gypsum; the thickest deposits exceed 55 feet at Laguna Grande de la Sal (Robinson and Lang, 1938, p. 85). The gypsum and other materials deposited in the other playas in Nash Draw are similar to those at Laguna Grande de la Sal, but the deposits are not as thick.

Windblown sands are common throughout most of the area east of Nash Draw. The sands are only a few feet thick except where they have been concentrated by wind into dunes. The greatest concentration of dunes is located east of James Ranch, where they may have a localized effect on the hydrology.

No wells in the WIPP site area are known to produce water from the surficial deposits or from the windblown sands; however, where these deposits are thickest, they may contain localized perched zones of ground water. The sand dunes east of James Ranch are very permeable; however, evapotranspiration probably removes most of the water. 
The playa deposits are known to contain water, but the water generally has such large salt concentrations that it is unusable. Robinson and Lang (1938, p. 95) reported the water associated with the Laguna Grande de la Sal playa was under a slight artesian head.

The alluvium associated with the Pecos River, especially north of Malaga Bend, is a productive aquifer. Transmissivities in the alluvium vary considerably, but calculations made by Bjorklund and Motts (1959, p. 191) average 13,600 feet squared per day; the hydraulic conductivity probably averages 116 feet per day. The average hydraulic conductivity, however, could be misleading; lime-cemented conglomerates in the alluvium may greatly increase the value because of solution channels. Detailed data for the alluvium can be found in studies by Hale, Hughes, and Cox (1954) and Bjorklund and Motts (1959). South of Malaga Bend, the alluvium is less extensive and more variable in thickness, so average hydraulic properties are more difficult to determine.

Where present, water associated with the surficial deposits and windblown sand probably is perched or semiperched; consequently, the occurrence of water is spotty and greatly dependent on local conditions. Recharge takes place in areas of surface ponding, and moves downward through fractures and joints into more permeable zones. In several trenches dug through sand dunes at the WIPP site, the sand was found to be unsaturated and no perched water was found. The high evapotranspiration rate in the area and the relatively impermeable underlying beds (caliche and siltstone) probably preclude large volumes of water moving downward.

The water in the playa deposits usually is localized, and water movement is restricted. The water table in the area around the playas slopes inward toward the playas, indicating water in the fill is moving into the playa and being discharged by evaporation. The source of the water is partly from recharge from precipitation and partly from ground-water inflow from springs (Robinson and Lang, 1938, p. 94).

Recharge to the alluvium is from several sources. Near Carlsbad, water moves from the Guadalupian reef complex to the alluvium. In the south near Malaga Bend, adjacent Permian geologic units, such as the Rustler, recharge the alluvium. Infiltration from precipitation and from streams, canals, and applied irrigation water also are sources of recharge to the alluvium. The alluvium near Malaga Bend is the most likely discharge area for water flow from hydrologic units associated with the WIPP site. The alluvium in this area probably would be the zone of contact with the biosphere if there should be a breach of the facility and a release of radionuclides. Water moving through the alluvium generally flows toward the Pecos River and then southwestward toward the Red Bluff Reservoir. Because the thick accumulations of sediment have been derived, to a great extent, from evaporites and fine-grained clastic rocks, the permeability of the alluvium is probably minimal, resulting in fairly low flow velocities (Hale and 
Clebsch, 1958, p. 15). However, localized zones of greater permeability may be present, especially where semiconsolidated alluvium is fractured. North of Malaga Bend, wells drilled into the alluvium vary in yield, but the yields are large enough to be used for irrigation.

The occurrence of water in the Tertiary and Quaternary rocks in the WIPP area generally is quite variable and is restricted to the area south of the WIPP site. The quality of ground water characteristically ranges from fresh to saline, although in isolated areas near playas it may be quite briny.

The only hydrologic unit that contains large volumes of water is the alluvium along the Pecos River. Although not specifically investigated during this study, it has been discussed in some detail in previous reports about the area (Hendrickson and Jones, 1952; Hale, Hughes and Cox, 1954; and Bjorklund and Motts, 1959). Generally, the chemical composition of the water in the alluvium near Malaga Bend is affected by brine inflow from the Permian rocks to the east, downward percolation of relatively fresh water from irrigation, and local dissolution of evaporites. This mixing has caused changes in the overall quality of the water, with dissolved constituents dominated by sodium and chloride. Hale, Hughes, and Cox (1954, p. 40) reported that the chloride concentration in the water in the alluvium increases with depth and a saturated brine is present in the lower part of the fill. The overall ionic composition of the water is similar to the ground water from the other hydrologic units, predominantly consisting of chlorides and sulfates of calcium, magnesium, sodium, and potassium.

\section{SURFACE-WATER HYDROLOGY}

There are no permanent streams or bodies of surface water present within the WIPP site; therefore, the potential for surface-water transport of waste is only treated briefly in this report. The purpose of these investigations was to relate surface water as a source or discharge point of flow from the ground-water system and as a potential part of the pathway for radionuclides if the WIPP facility were breached.

The Pecos River is a perennial stream and is the major drainage for the region around WIPP. The Pecos River is located west-southwest of the WIPP site and, at its closest point, is 10 miles from the outer exclusion boundary of the WIPP site. Most local tributaries originate in the Guadalupe Mountains, to the west of the Pecos. East of the Pecos, including Los Medaños and the WIPP site, the surface drainage is almost undeveloped. The closest major drainage to the WIPP site is Nash Draw; however, it is a closed 
drainage area with no surface outlet to the Pecos River. The land surface of the WIPP site is very hummocky and contains numerous sma11 topographic depressions, which generally contain what little surface runoff takes place. A surface-water gaging station was established near Hill Tank (fig. la) on an unnamed arroyo draining from the WIPP site to Nash Draw (in sec. 24, T. 22 S., R. 30 E.). During 4 years, only one flow occurred and it was of such short duration that it could not be measured. Apparently, surface runoff from the WIPP site is minimal; most surface water is lost to evapotranspiration.

The most significant effect of surface water on the hydrology of the WIPP site takes place at Malaga Bend on the Pecos River where water from the Rustler Formation discharges to the river. Additional data on the Pecos River and the regional surface-water conditions are included in the report by Powers, Lambert, Shaffer, Hill, and Weart (1978).

\section{SUMMARY AND CONCLUSIONS}

The WIPP site is proposed as a radioactive-waste storage facility to be placed at a depth of approximately 2,150 feet in bedded salts of the Permian Salado Formation. The characteristics of the geohydrologic systems at the WIPP site need to be defined because of the potential for transport of radionuclides to the biosphere by ground water in the event the storage facility is breached.

The Guadalupian reef complex is a major hydrologic unit in the area and forms a long arcuate belt around the margins of the Delaware Basin in which the WIPP site is located. Lateral movement of water away from the reef is restricted by the minima1ly permeable anhydrites of the Castile Formation.

The sedimentary formations in the WIPP site area that contain water are present both below and above the halite of the Salado Formation. The formations of concern range in age from Permian to Quaternary. About 70 test holes have been drilled as part of the geologic and hydrologic site characterization.

The major water-bearing zones below the Salado Formation that have been identified during hydrologic investigations are the fine-grained sandstones of the Bell Canyon Formation of the Delaware Mountain Group. In addition, isolated pockets of pressurized brine have been found in fractures in the anhydrite of the Castile Formation. Investigations to date (1983) indicate that these zones are isolated from units either above or below the Castile. The water-bearing zones of concern above the Salado Formation include a zone composed of the residue from evaporite dissolution at the contact between the Rustler and Salado Formations and the Magenta and Culebra Dolomite Members of the Rustler Formation. Where present, water in Tertiary and Quaternary sediments (other than on the Pecos River flood plain) is perched in isolated sands . 
Water-bearing units in the Delaware Mountain Group probably are restricted to the upper 600 feet of the Bell Canyon Formation; the individual permeable sandstone beds are no thicker than 60 feet. The dissolved ions in the brines of the Bell Canyon in the WIPP site area are predominantly sodium and chloride; dissolved-solids concentrations range from 180,000 to 270,000 milligrams per liter.

In the upper part of the Bell Canyon Formation, the brines usually are present in relatively isolated permeable channel sandstones, which have hydraulic conductivities ranging from $7 \times 10^{-3}$ to $5 \times 10^{-2}$ foot per day. These channel sandstones grade vertically and laterally into siltstones and shales that have negligible permeability; hydraulic conductivities usually are less than $2 \times 10^{-6}$ foot per day. Siltstones and shales overlying these channel sandstones restrict upward movement of water to the minimally permeable anhydrites of the Castile Formation. Potentiometric-surface maps indicate water movement across the basin to the northeast; however, the rate of movement is extremely slow. The hydraulic heads in the permeable units overlying the evaporites indicate that the general movement would be downward; that is, hydraulic head decreases with depth.

The hydrologic units of the Rustler Formation are the principal water-bearing units above the Salado Formation in the WIPP site vicinity and thus have been the most extensively studied. Water-bearing units in the Rustler Formation include the residues (residuum) from evaporite dissolution at the contact between the Rustler and Salado Formations and the Culebra Dolomite and Magenta Dolomite Members.

Brine at the Rustler-Salado contact "brine aquifer" of Robinson and Lang (1938) is present either in a clay residuum bed or along the bedding planes between these units. The residuum is common along Nash Draw and is most extensive between Laguna Grande de $\mathrm{la} \mathrm{Sal}$ and Malaga Bend, where transmissivities are as large as 8,000 feet squared per day. In the northern end of Nash Draw, transmissivities range from $2 \times 10^{-4}$ foot squared per day in test hole $W-27$ to 8 feet squared per day in test hole $W-29$; in the WIPP site proper, transmissivities range from $3 \times 10^{-5}$ foot squared per day at test holes $\mathrm{H}-5 \mathrm{C}$ and $\mathrm{P}-18$ to $5 \times 10^{-2}$ foot squared per day at test hole $\mathrm{P}-14$. The ground-water flow in the eastern part of the site primarily is along bedding planes. Density-corrected potentiometric-surface maps indicate flow is southwest across the WIPP site towards Nash Draw at a gradient of 39 feet per mile and then south-southwest down Nash Draw to Malaga Bend on the Pecos River at a gradient of about 10 feet per mile. The dissolved ions in the brines of the Rustler-Salado contact residuum are predominantly sodium and chloride; dissolved-solids concentrations range from 79,800 milligrams per liter at test hole $\mathrm{H}-7 \mathrm{C}$ to 480,000 milligrams per liter at test hole $\mathrm{H}-1$. Large concentrations of dissolved potassium and magnesium in ground water in the eastern part of the study area indicate restricted flow and extensive interaction between the ground water and its host rock. 
The Culebra Dolomite Member of the Rustler Formation is the most persistent and productive hydrologic unit in the WIPP vicinity. Its hydraulic properties vary considerably from place to place, primarily as a result of the size and number of fractures and openings. These fractures are related to the degree of evaporite dissolution within the Rustler, which causes subsidence and collapse of the overlying dolomite. The most extensive evaporite dissolution and fracturing are present in Nash Draw. Transmissivities calculated for the Culebra in Nash Draw range from 18 feet squared per day at test hole $W-28$ to 1,250 feet squared per day at test hole W-26. At the WIPP site, east of Nash Draw, transmissivities range from $1.0 \mathrm{x}$ $10^{-3}$ foot squared per day at test hole P-18 to 140 feet squared per day at test hole P-14. Density-corrected potentiometric-surface maps indicate that flow at the WIPP site is to the south at a hydraulic gradient that ranges from 7 to 20 feet per mile; the flow is then to the southwest to Nash Draw, where gradients range from 16 feet per mile in the north end to less than 5 feet per mile near Malaga Bend. Flow directions may be affected significantly by directional differences in permeability in the dolomite. In Nash Draw, the Culebra Dolomite is extensively fractured and flow is south to a discharge area at the Pecos River near Malaga Bend.

Water in the Culebra is slightly saline to briny; dissolved-solids concentrations range from 3,200 milligrams per liter at test hole $\mathrm{H}-8 \mathrm{~B}$ to 420,000 milligrams per liter at test hole P-18. Dominant dissolved ions are sodium and chloride; other ions include sulfate, potassium, calcium, and magnesium. Not only does the mineralization of the water generally increase from west to east across the site, but so do the concentrations of potassium and magnesium. This change indicates a decrease in circulation along the eastern side of the WIPP site. This restricted circulation is caused by a decrease in permeability.

The Magenta Dolomite Member is the uppermost hydrologic unit in the Rustler Formation. Water is present in the area of the WIPP site, usually in thin siltstone beds or silty dolomite and less commonly in fractures. In Nash Draw, the occurrence of water in the Magenta Dolomite Member is variable because of localized drainage from the unit that results from the chaotic structure created by extensive evaporite dissolution. In the southern end of Nash Draw, the Magenta has been completely removed by erosion. Transmissivities calculated for the Magenta Dolomite in the northern end of Nash Draw range from 53 feet squared per day at test hole W-27 to 375 feet squared per day at test hole $\mathrm{W}-25$; these relatively large values result from the increased permeability in the fractured rock. The transmissivity in the vicinity of the WIPP site ranges from $4 \times 10^{-3}$ foot squared per day at test hole $W-30$ to $3 \times 10^{-1}$ foot squared per day at test hole H-6A. The movement of ground water in the site area, as estimated from density-corrected potentiometric-surface maps, is west toward Nash Draw at a gradient of as much as 32 feet per mile and then southwest in Nash Draw at a gradient of 13 feet per mile. 
The flow in the Magenta Dolomite Member eventually moves downward through fractures into lower units. The water in the Magenta is saline to briny; concentrations of dissolved solids range from 5,460 milligrams per liter at test hole $\mathrm{H}-9 \mathrm{a}$ to 270,000 milligrams per 1iter at test hole $\mathrm{H}-10 \mathrm{~A}$. Dissolved-mineral constituents of the water include sulfates and chlorides of sodium, magnesium, potassium, and calcium, the major percentages being sodium and chloride. Larger magnesium and potassium concentrations in the eastern part of the site may indicate restricted circulation in the Magenta.

The relative static heads or formation pressures of the hydrologic units in the Rustler Formation decrease with depth; that is, hydraulic heads are highest in the Magenta and lowest at the Rustler-Salado contact. There appear to be two regional flow systems; one in the area around the proposed WIPP site and one in Nash Draw. In the WIPP site area, the presence of impermeable interbeds of halite and anhydrite and the differences in static head and water quality probably indicate restricted vertical hydraulic connection between units; however, in Nash Draw, where dissolution and subsidence are more common, hydraulic connection between units probably exists. Recharge for the Rustler units probably takes place to the north of Nash Draw near Bear Grass Draw; the major discharge takes place at Malaga Bend on the Pecos River. 


\section{REFERENCES}

Adams, J. E., 1944, Upper Permian Ochoa series of Delaware Basin of west Texas and southeastern New Mexico: American Association of Petroleum Geologists Bulletin, v. 28, no. 11, p. 1596-1625.

Anderson, R. Y., 1978, Deep dissolution of salt, northern Delaware Basin, New Mexico: Consultant's report to Sandia Laboratories, 106 p.

1981, Deep-seated salt dissolution in the Delaware Basin, Texas and New Mexico in Environmental geology and hydrology in New Mexico, 1981: New Mexico Geological Society Special Publication 10, p. 133-145.

Anderson, R. Y., Dean, W. E., Jr., Kirkland, D. W., and Snider, H. I., 1972, Permian Castile varved evaporite sequence, west Texas and New Mexico: Geological Society of America Bulletin, v. 83, p. 59-86.

Bachman, G. 0., 1973, Surficial features and late Cenozoic history in southeastern New Mexico: U.S. Geological Survey Open-File Report 73-13, $32 \mathrm{p}$.

, 1974, Geological processes and Cenozoic history related to salt dissolution in southeastern New Mexico: U.S. Geological Survey Open-File Report 74-194, 81 p.

, 1976, Cenozoic deposits of southeastern New Mexico and an outline of the history of evaporite dissolution: U.S. Geological Survey Journal of Research, v. 4, no. 2, p. 135-149.

, 1980, Regional geology and Cenozoic history of Pecos region, southeastern New Mexico: U.S. Geological Survey Open-File Report 80-1099, $116 \mathrm{p}$.

, 1981, Geology of Nash Draw, Eddy County, New Mexico: U.S. Geological Survey Open-File Report 81-31, 8 p.

Basler, J. A., 1983, Instrumentation used for hydraulic testing of potential water-bearing formations at the Waste Isolation Pilot Plant site in southeastern New Mexico: U.S. Geological Survey Open-File Report $83-144,29$ p.

Berg, R. R., 1979, Reservoir Sandstones of the Delaware Mountain Group, southeast New Mexico, in Guadalupian Delaware Mountain Group of west Texas and southeast New Mexico: Society of Economic Paleontologists and Mineralogists, Permian Basin Section Publication 79-18, p. 75-95.

Bjorklund, L. J., and Motts, W. S., 1959, Geology and water resources of the Carlsbad area, New Mexico: U.S. Geological Survey Open-File Report $59-9,322 \mathrm{p}$. 


\section{REFERENCES}

Bond, D. C., 1972, Hydrodynamics in deep aquifers of the Illinois Basin: Illinois State Geological Survey Circular 470, 50 p.

Bredehoeft, J. D., and Papadopulos, S. S., 1980, A method for determining the hydraulic properties of tight formations: Water Resources Research, v. 16, no. 1, p. 233-238.

Brokaw, A. L., Jones, C. L., Cooley M. E., and Hays, W. H., 1972, Geology and hydrology of the Carlsbad potash area, Eddy and Lea Counties, New Mexico: U.S. Geological Survey Open-File Report 72-49, 86 p.

Cooper, H. H., Jr., Bredehoeft, J. D., and Papadopulos, I. S., 1967, Response of a finite-diameter well to an instantaneous charge of water: Water Resources Research, v. 3, no. 1, p. 263-269.

Cooper, J. B., 1960, Geologic section from Carlsbad Caverns National Park through Project Gnome site, Eddy and Lea Counties, New Mexico: U.S. Geological Survey Trace Element Investigation Report 767, 1 sheet.

, 1961, Test holes drilled in support of ground-water investigations, Project GNOME, Eddy County, New Mexico basic data report: U.S. Geological Survey Trace Element Investigation Report 786, 116 p. , 1962a, Ground-water investigations of the Project Gnome area, Eddy and Lea Counties, New Mexico: U.S. Geological Survey Trace Element Investigation Report 802,67 p.

, 1962b, Ground water in Cenozoic fill in collapse structures, southeastern Eddy County, New Mexico, in Short papers in geology, hydrology, and topography, 1962: U.S. Geological Survey Professional Paper 450-B, p. E152-E153.

Cooper, J. B., and Glanzman, V. M., 1971, Geohydrology of Project Gnome site, Eddy County, New Mexico: U.S. Geological Survey Professional Paper $712-\mathrm{A}, 24 \mathrm{p}$.

Cooper, J. B., and others, 1962, Hydrologic and geologic studies for Project Gnome, preliminary report: U.S. Geological Survey Project Gnome Report PNE-130P, $54 \mathrm{p}$.

Cox, E. R., and Havens, J. S., 1961, Evaluation of the Queen Lake Depression, Eddy County, New Mexico, as a storage basin for brine: U.S. Geological Survey open-file report, $110 \mathrm{p}$.

Cox, E. R., and Havens, J. S., 1965, A progress report on the Malaga Bend Experimental Salinity Alleviation Project, Eddy County, New Mexico: U.S. Geological Survey Open-File Report 65-35, 91 p. 


\section{REFERENCES}

Cox, E. R., and Kunkler, J. L., 1962, Feasibility of injecting brine from Malaga Bend into the Delaware Mountain Group, Eddy County, New Mexico: U.S. Geological Survey open-file report, 69 p.

Darton, N. H., 1922, Geologic structure of parts of New Mexico in Contributions to economic geology, 1921-Part 2: U.S. Geological Survey Bulletin 726-E, p. 173-275.

Dennehy, K. F., 1982, Results of hydrologic tests and water-chemistry analyses, wells $\mathrm{H}-6 \mathrm{~A}, \mathrm{H}-6 \mathrm{~B}$, and $\mathrm{H}-6 \mathrm{C}$ at the proposed Waste Isolation Pilot Plant site, southeastern New Mexico: U.S. Geological Survey Water-Resources Investigations $82-8,68 \mathrm{p}$.

Dennehy, K. F., and Mercer, J. W., 1982, Results of hydrologic tests and water-chemistry analyses, wells $\mathrm{H}-5 \mathrm{~A}, \mathrm{H}-5 \mathrm{~B}$, and $\mathrm{H}-5 \mathrm{C}$ at the proposed Waste Isolation Pilot Plant site, southeastern New Mexico: U.S. Geological Survey Water-Resources Investigations $82-19,83$ p.

Gard, L. M., Jr., 1968, Geologic studies Project Gnome, Eddy County, New Mexico: U.S. Geological Survey Professional Paper 589, 33 p.

Gonzalez, D. D., 1983, Ground-water flow in the Rustler Formation, Waste Isolation Pilot Plant site, southeast New Mexico: Sandia National Laboratories Report SAND 82-1012, Albuquerque, New Mexico, 47 p.

Grauten, W. F., 1965, Fluid relationships in Delaware Mountain Sandstone, in Fluids in subsurface environments: American Association of Petroleum Geologists Memoir 4, p. 294-308.

Griswold, G., 1980, Summary of brine flow in Geotechnical consideration for radiological hazard assessment of WIPP: State of New Mexico Environmental Evaluation Group Report EEG-6, p. 16-22.

Grove, D. B., and Beetem, W. A., 1971, Porosity and dispersion constant calculations for a fractured carbonate aquifer using the two well tracer method: Water Resources Research, v. 7, no. 1, p. 128-134.

Hale, W. E., 1945a, Ground-water conditions in the vicinity of Carlsbad, New Mexico in 16 th and 17 th Biennial Reports: New Mexico State Engineer, p. $195-\overline{250}$.

, 1945b, Ground-water conditions in the vicinity of Rattlesnake Springs, Eddy County, New Mexico: New Mexico State Engineer Technical Report 3, $54 \mathrm{p}$.

, 1961, Availability of ground water in New Mexico, in Sixth annual New Mexico water conference, November 1-2, 1961: New Mexico State University, Las Cruces, New Mexico, p. 11-22. 


\section{REFERENCES}

Hale, W. E., and Clebsch, Alfred, Jr., 1958, Preliminary appraisal of ground-water conditions in southeastern Eddy County and southwestern Lea County, New Mexico: U.S. Geological Survey Trace Element Memorandum Report 1045, 23 p.

Hale, W. E., Hughes, L. S., and Cox, E. R., 1954, Possible improvement of quality of water of the Pecos River by diversion of brine at Malaga Bend, Eddy County, New Mexico: Pecos River Commission, 43 p.

Halpenny, L. C., and Greene, D. K., 1966, Water rights and water supply, city of Carlsbad, investigation of present situation and future requirements: Water Development Corporation, Tucson, Arizona, 85 p.

Harms, J. C. 1974, Brushy Canyon Formation, Texas: Geological Society of America Bulletin, v. 85, p. 1763-1784.

Havens, J. S., and Wilkins, D. W., 1980, Experimental salinity alleviation at Malaga Bend of the Pecos River, Eddy County, New Mexico: U.S. Geological Survey Water-Resources Investigations 80-4, 65 p.

Hayes, P. T., 1964, Geology of the Guadalupe Mountains, New Mexico: U.S. Geological Survey Professional Paper 446, 69 p.

Hendrickson, G. E., and Jones, R. S., 1952, Geology and ground-water resources of Eddy County, New Mexico: New Mexico Bureau of Mines and Mineral Resources Ground-Water Report 3, 169 p.

Hiss, W. L., 1976, Stratigraphy and ground-water hydrology of the Capitan aquifer, southeastern New Mexico and west Texas: University of Colorado, Boulder, unpublished Ph.D. dissertation, 396 p.

, 1980, Movement of ground water in Permian Guadalupian aquifer systems, southeastern New Mexico and western Texas; in Trans-Pecos Region: New Mexico Geological Society, 31st Field Conference, p. 289-294.

Hubbert, M. K., 1953, Entrapment of petroleum under hydrodynamic conditions: American Association of Petroleum Geologists Bulletin, v. 37, no. 8, p. 1957-2026.

Jones, C. L., 1954, The occurrence and distribution of potassium minerals in southeastern New Mexico, in Guidebook to southeastern New Mexico: New Mexico Geological Society, 5th Field Conference, p. 107-112.

, 1959, Thickness, character, and structure of upper Permian evaporites in part of Eddy County, New Mexico: U.S. Geological Survey Trace Element Memorandum Report 1033, 19 p., 2 figs.

1972, Permian Basin potash deposits, southwestern United States, in Geology of saline deposits: UNESCO, Earth Science Services 7, p. 191-201. 


\section{REFERENCES}

Jones, C. L., 1973, Salt deposits of Los Medaños area, Eddy and Lea Counties, New Mexico, with sections on Ground-water hydrology by M. E. Cooley, and Surficial geology by G. 0. Bachman: U.S. Geological Survey Open-File Report 73-135, $67 \mathrm{p}$.

, 1975, Potash resources in part of Los Medaños area of Eddy and Lea Counties, New Mexico: U.S. Geological Survey Open-File Report 75-407, $37 \mathrm{p}$.

1978, Test drilling for potash resources, Waste Isolation Pilot

Plant Site, Eddy County, New Mexico: U.S. Geological Survey Open-File Report 78-592, 2 vols., 431 p.

Jones, C. L, Bowles, C. G., and Bell, K. G., 1960, Experimental drill hole logging in potash deposits of the Carlsbad District, New Mexico: U.S. Geological Survey Open-File Report 60-84, 25 p.

Jones, C. L., and Madsen, B. M., 1959, Observations on igneous intrusions in late Permian evaporites, southeastern New Mexico: Geological Society of America Bulletin, v. 70, p. 1625-1626.

Jorgensen, D. G., Goge1, Tony, and Signor, D. C., 1982, Determination of flow in aquifers containing variable-density water: Ground Water Monitoring Review, v. 2, no. 2, p. 40-45.

King, P. B., 1948, Geology of the southern Guadalupe Mountains, Texas: U.S. Geological Survey Professional Paper 215, 188 p.

Kunkler, J. L., 1980, Evaluation of the Malaga Bend salinity alleviation project, Eddy County, New Mexico: U.S. Geological Survey Open-File Report 80-1111, $31 \mathrm{p}$.

Lambert, S. J., 1978, Geochemistry of Delaware Basin ground waters, in Geology and mineral deposits of Ochoan rocks in Delaware Basin and adjacent areas: New Mexico Bureau of Mines and Mineral Resources Circular 159, p. 33-38.

, 1982, Interim report--dissolution of evaporites in and around the Delaware Basin, southeastern New Mexico and west Texas: Sandia National Laboratories Report SAND 82-0461, Albuquerque, New Mexico, 171 p.

Lambert, S. J., and Mercer, J. W., 1977, Hydrologic investigations of Los Medaños area, southeast New Mexico, 1977: Sandia National Laboratories Report SAND 77-1401, Albuquerque, New Mexico, 56 p.

Lang, W. B., 1935, Upper Permian formations of Delaware Basin of Texas and New Mexico: American Association of Petroleum Geologists Bulletin, v. 19 , no. 2 , p. 262-270. 


\section{REFERENCES}

Lang, W. B., 1937, Permian formations of the Pecos valley of New Mexico and Texas: American Association of Petroleum Geologists Bulletin, v. 21, p. 833-898.

1938, Geology of the Pecos River between Laguna Grande de la Sal and Pierce Canyon, in $12 \mathrm{th}$ and $13 \mathrm{th}$ biennial reports: New Mexico State Engineer, p. 80-86.

Lee, W. T., 1925, Erosion by solution and fill, in Contributions to geography in the United States: U.S. Geological Survey Bulletin 760-C, p. 107-121.

Lohman, S. W., 1972, Ground-water hydraulics: U.S. Geological Survey Professional Paper 708, 70 p.

Maley, V. C., and Huffington, R. M., 1953, Cenozoic fill and evaporite solution in Delaware Basin, Texas and New Mexico: Geological Society of America Bulletin, v. 64, no. 5, p. 539-546.

McNeal, R. P., 1965, Hydrodynamics of the Permian Basin, in Fluids in subsurface environments: American Association of Petroleum Geologists Memoir 4, p. 308-326.

Meinzer, 0. E., 1923a, The occurrence of ground water in the United States, with a discussion on principles: U.S. Geological Survey Water-Supply Paper 489, 321 p.

$1923 \mathrm{~b}$, Outline of ground-water hydrology, with definitions: U.S. Geological Survey Water-Supply Paper 494, 71 p.

Meissner, F. F., 1972, Cyclic sedimentation in middle Permian strata of the Permian Basin, West Texas and New Mexico, in Cyclic sedimentation in the Permian Basin: West Texas Geological Society Publication 72-60, p. 203-232.

Mercer, J. W., Davis, Pau1, Dennehy, K. F., and Goetz, C. L., 1981, Results of hydrologic tests and water-chemistry analyses, wells $\mathrm{H}-4 \mathrm{~A}, \mathrm{H}-4 \mathrm{~B}$, and $\mathrm{H}-4 \mathrm{C}$ at the proposed Waste Isolation Pilot Plant site, southeastern New Mexico: U.S. Geological Survey Water-Resources Investigations 81-36, $92 \mathrm{p}$.

Mercer, J. W., and Gonzalez, D. D., 1981, Geohydrology of the proposed Waste Isolation Pilot Plant in southeastern New Mexico, in Environmental geology and hydrology in New Mexico, 1981: New Mexico Geological Society Special Publication no. 10, p. 123-131.

Mercer, J. W., and Orr, B. R., 1977, Review and analysis of hydrogeologic conditions near the site of a potential nuclear-waste repository, Eddy and Lea Counties, New Mexico: U.S. Geological Survey Open-File Report $77-123,35 \mathrm{p}$. 


\section{REFERENCES}

Mercer, J. W., and Orr, B. R., 1979, Interim data report on the geohydrology of the proposed Waste Isolation Pilot Plant site, southeast New Mexico: U.S. Geological Survey Water-Resources Investigations 79-98, 178 p.

Motts, W. S., 1968, The control of ground-water occurrence by lithofacies in the Guadalupian reef complex near Carlsbad, New Mexico: Geological Society America Bulletin, v. 79, no. 3, p. 283-298.

Newe11, N. D., Rigby, J. K., Fischer, A. G., Whiteman, A. J., Hickox, J. E., and Bradley, J. S., 1953, The Permian reef complex of the Guadalupe Mountains region, Texas and New Mexico--a study in paleoecology: W. H. Freeman \& Co., San Francisco, 236 p.

Nicholson, Alexander, Jr., and Clebsch, Alfred, Jr., 1961, Geology and ground-water conditions in southern Lea County, New Mexico: New Mexico Bureau of Mines and Mineral Resources Ground-water Report 6, 120 p.

Oriel, S. S., Myers, D. A., and Crosby, E. J., 1967, West Texas Permian Basin region, in McKee, E. D., and Oriel, S. S., eds., Paleotectonic investigations of the Permian System in the United States: U.S. Geological Survey Professional Paper 515, p. 17-60.

Page, L. R., and Adams, J. E., 1940, Stratigraphy, eastern Midland Basin, Texas, in Deford, R. K., and Lloyd, E. R., eds., West Texas - New Mexico symposium, pt. 1: American Association of Petroleum Geologists Bulletin, v. 24, no. 1, p. 52-64.

Papadopulos, S. S., Bredehoeft, J. D., and Cooper, H. H., Jr., 1973, On the analysis of "slug test" data: Water Resources Research, v. 9, no. 4, p. 1087-1089.

Peterson, E. W., Lagus, P. L., Broce, R. D., and Lie, K., 1981, In situ permeability testing of rock salt: Sandia National Laboratories Report SAND 81-7073, Albuquerque, New Mexico, 65 p.

Powers, D. W., 1981, Geologic investigations of the WIPP site--overview and issues, in Environmental geology and hydrology in New Mexico, 1981: New Mexico Geological Society Special Publication no. 10, p. 119-122.

Powers, D. W., Lambert, S. J., Shaffer, S. E., Hill, L. R., and Weart, W. D., editors, 1978, Geological characterization report, Waste Isolation Pilot Plant (WIPP) site, southeastern New Mexico: Sandia Laboratories Report SAND 78-1596, Albuquerque, New Mexico, two volumes, var. p.

Register, J. K., 1981, Brine pocket occurrences in the Castile Formation, southeastern New Mexico: Department of Energy TME 3080, 14 p.

Richardson, G. B., 1904, Report of a reconnaissance in Trans-Pecos Texas, north of Texas and Pacific Railway: Texas University Mineralogical Survey Bulletin 9, and Texas University Bulletin 23, 119 p. 


\section{REFERENCES}

Robinson, T. W., and Lang, W. B., 1938, Geology and ground-water conditions of the Pecos River valley in the vicinity of Laguna Grande de la Sal, New Mexico, in $12 \mathrm{th}$ and $13 \mathrm{th}$ biennal reports: New Mexico State Engineer, p. 77-100.

Sandia National Laboratories and University of New Mexico, 1981, Basic data report for drillhole WIPP 15 (Waste Isolation Pilot Plant--WIPP): Sandia National Laboratories Report SAND 79-0274, Albuquerque, New Mexico, 80 p.

Silver, B. A., and Todd, R. G., 1969, Permian cyclic strata, northern Midland and Delaware Basins, west Texas and southeastern New Mexico: American Association of Petroleum Geologists Bulletin, v. 53, no. 11, p. 2223-2251.

Sullivan, N. M., editor, 1979, Guadalupian Delaware Mountain Group of west Texas and southeast New Mexico: Permian Basin Society Sdction of Economic Paleontologists and Mineralogists Publication 79-18, 244 p.

Theis, C. V., and Sayre, A. N., 1942, Geology and ground water, in U.S. National Resources Planning Board, 1942, Pecos River Joint Investigation --Reports of the participating agencies: Washington, U.S. Government Printing Office, p. 27-75.

Tolman, C. F., 1937, Ground water: McGraw-Hill Book Company, Inc., New York and London, $593 \mathrm{p}$.

Vine, J. D., 1963, Surface geology of the Nash Draw quadrangle, Eddy County, New Mexico: U.S. Geological Survey Bulletin 1141-B, 46 p.

Watson, W. G., 1979, Inhomogeneities of the Ramsey Member of the Permian Bell Canyon Formation, Geraldine Ford Field, Culberson and Reeves Counties, Texas, in Guadalupian Delaware Mountain Group of west Texas and southeast New Mexico: Permian Basin Society Section of Economic Paleontologists and Mineralogists Publication 79-18, p. 2-38.

Williamson, C. R., 1979, Deep-sea sedimentation and stratagraphic traps, Bell Canyon Formation (Permian) Delaware Basin, in Guadalupian Delaware Mountain Group of west Texas and southeast New Mexico: Permian Basin Society Section of Economic Paleontologists and Mineralogists Publication 79-18, p. 39-74. 
Table 1. Geologic and hydrologic data from test holes drilled at and near the proposed Waste Isolation Pilot Plant site

[FNL, from north line; FEL, from east line, FSL, from south line; FWL, from west line; Sec., Section; T, Township; R. Range; units, in feet below land surface R; Rustler Formation; S, Salado Formation]

\begin{tabular}{|c|c|c|c|c|c|c|c|c|c|c|}
\hline \multirow[b]{2}{*}{$\begin{array}{l}\text { Test } \\
\text { hole }\end{array}$} & \multirow[b]{2}{*}{$\begin{array}{l}\text { Altitude, } \\
\text { in feet } \\
\text { above } \\
\text { sea level }\end{array}$} & \multicolumn{5}{|c|}{ Location } & \multicolumn{4}{|c|}{ Depth of rock } \\
\hline & & Sec. & $\mathrm{T}$ & & $\begin{array}{l}\text { Distance, } \\
\text { from sect }\end{array}$ & $\begin{array}{l}\text {, in feet, } \\
\text { tion lines }\end{array}$ & $\begin{array}{l}\text { Surficial } \\
\text { deposits }\end{array}$ & $\begin{array}{l}\text { Gatuna } \\
\text { Formation } \\
\end{array}$ & $\begin{array}{l}\text { Santa Rosa } \\
\text { Formation }\end{array}$ & $\begin{array}{l}\text { Dewey Lake } \\
\text { Red Beds }\end{array}$ \\
\hline$H-1$ & 3397.71 & 29 & 225 & $31 E$ & $623.31 \mathrm{FNL}$ & $1082.75 F E L$ & 0.15 & $15-35$ & $\begin{array}{l}\text { N.P., (Not } \\
\text { Present) }\end{array}$ & $35-502$ \\
\hline$H-2 A$ & 3377.85 & 29 & 225 & $31 E$ & $726.17 F N L$ & $1698.43 \mathrm{FWL}$ & $0-14$ & $14-38$ & N.P. & $38-457$ \\
\hline$H-20$ & 3377.68 & & do & & $695.57 \mathrm{FNL}$ & $1660.57 \mathrm{FWL}$ & do & do & N.P. & do \\
\hline$H-2 C$ & 3377.75 & & do & & $637.15 \mathrm{FNL}$ & $1708.62 \mathrm{FWL}$ & do & do & N.P. & do \\
\hline$H-3$ & 338948 & 29 & 225 & 3IE & $2085.30 \mathrm{FSL}$ & 138.1FEL & $0-4$ & $4-22$ & N.P. & $22-502$ \\
\hline$H-4 A$ & 3332.91 & 5 & 235 & $31 E$ & $545.89 \mathrm{FNL}$ & $720.00 \mathrm{FWL}$ & $0-13$ & $13-29$ & N.P. & $29-315$ \\
\hline$H-4 B$ & 3332.76 & & do & & $498.47 F \mathrm{FL}$ & $632.54 \mathrm{FWL}$ & do & do & N.P. & do \\
\hline$M-4 C$ & 3333.54 & & do & & $446.36 \mathrm{FNL}$ & $717.89 \mathrm{FWL}$ & do & do & N.P. & do \\
\hline$H-5 A$ & 3506.15 & 15 & 225 & $31 E$ & $1093.12 \mathrm{FNL}^{\circ}$ & $184.33 \mathrm{FEL}$ & $0-8$ & $\begin{array}{l}\text { N.P. (Not } \\
\text { Present) }\end{array}$ & $8-225$ & $225-732$ \\
\hline$H-5 B$ & 3505.97 & & do & & $1006.80 \mathrm{FNL}$ & $234.21 F E L$ & do & N.P. & do & do \\
\hline$H-5 C$ & 3506.37 & & do & & $1006.47 \mathrm{FNL}$ & $134.20 \mathrm{FEL}$ & do & N.P. & do & do \\
\hline$H-6 A$ & 3347.26 & 182 & 225 & 3IE & $283.80 \mathrm{FNL}$ & $274.93 \mathrm{FWL}$ & $0-12$ & $12-38$ & N.P. & $38-427$ \\
\hline$H-6 B$ & 3347.57 & & do & & $195.61 \mathrm{FNL}$ & $322.15 \mathrm{FWL}$ & do & do & N.P. & do \\
\hline$H-6 C$ & 3347.93 & & do & & $280.61 \mathrm{FNL}$ & $374.81 \mathrm{FWL}$ & do & do & N.P. & do \\
\hline$H-7 A$ & 3163.55 & 14 & 235 & $30 E$ & $2495.04 \mathrm{FNL}$ & $2492.35 \mathrm{FWL}$ & $0-5$ & & N.P. & $57-87$ \\
\hline $\mathrm{H}-7 \mathrm{~B}$ & 3163.63 & & do & & $2565.8 F N L$ & $2563.45 \mathrm{FWL}$ & do & do & N.P. & do \\
\hline $\mathrm{H}-7 \mathrm{C}$ & 3163.48 & & do & & $2591.93 \mathrm{FNL}$ & $2467.51 \mathrm{FWL}$ & do & do & & do \\
\hline$H-8 A$ & 3433.0 & 23 & $24 \mathrm{~S}$ & $30 \mathrm{E}$ & $1962.61 \mathrm{FNL}$ & $1486.59 \mathrm{FEL}$ & $\begin{array}{l}0-4 \quad 4-10 \\
\text { Mescalero } \\
\text { Caliche }\end{array}$ & $10-153$ & N.P. & $153-399$ \\
\hline H-8B & 3433.8 & & do & & $1994.76 \mathrm{FNL}$ & $1405.39 \mathrm{FEL}$ & do & do & N.P. & do \\
\hline $\mathrm{H}-8 \mathrm{C}$ & 3433.0 & & do & & 2059.39FNL & $1470.14 \mathrm{FEL}$ & do & do & N.P. & do \\
\hline$H-9 A$ & 3405.4 & 4 & $24 \mathrm{~S}$ & 31E & 2392. 14FNL & $138.92 \mathrm{FWL}$ & $0-5$ & $5-25$ & N.P. & $24-455$ \\
\hline $\mathrm{H}-9 \mathrm{~B}$ & 3405.6 & & do & & $2391.04 \mathrm{FNL}$ & $283.63 \mathrm{FWL}$ & do & do & N.P. & do \\
\hline $\mathrm{H}-9 \mathrm{C}$ & 3405.9 & & do & & $2479.06 \mathrm{FNL}$ & $188.02 \mathrm{FWL}$ & do & do & N.P. & do \\
\hline$H-10 A$ & 3686.52 & 20 & 235 & $32 \mathrm{E}$ & $433.04 \mathrm{FSL}$ & 2068.91FEL & $0-9$ & $9-90$ & $\begin{array}{r}90-482 \\
\text { Chinle } \\
482-658\end{array}$ & $658-1204$ \\
\hline$H-10 B$ & 3687.01 & & do & & $484.54 \mathrm{FSL}$ & 1984.84FEL & do & do & do & do \\
\hline $\mathrm{H}-10 \mathrm{C}$ & 3686.88 & & do & & $384.54 \mathrm{FSL}$ & $1981.84 \mathrm{FEL}$ & do & do & do & do \\
\hline
\end{tabular}




\begin{tabular}{|c|c|c|c|c|c|c|c|}
\hline $\begin{array}{l}\text { Rustler } \\
\text { Formation }\end{array}$ & $\begin{array}{l}\text { Magenta } \\
\text { Dolomite } \\
\text { Member of } \\
\text { Rustler } \\
\text { Formation } \\
\end{array}$ & $\begin{array}{l}\text { Culebra } \\
\text { Dolomite } \\
\text { Member of } \\
\text { Rustler } \\
\text { Formation }\end{array}$ & $\begin{array}{l}\text { Top of } \\
\text { Salado } \\
\text { Formation }\end{array}$ & $\begin{array}{l}\text { Top of } \\
\text { salt in } \\
\text { Salado } \\
\text { Formation }\end{array}$ & $\begin{array}{l}\text { Top of } \\
\text { McNutt } \\
\text { potash } \\
\text { zone }\end{array}$ & $\begin{array}{l}\text { Top of } \\
\text { Castile } \\
\text { Formation }\end{array}$ & $\begin{array}{l}\text { Test } \\
\text { hole } \\
\text { depth } \\
\text { in feet }\end{array}$ \\
\hline $502-824$ & $563-589$ & $676-699$ & 824 & $731(\mathrm{R})$ & & & 856 \\
\hline $457-$ & $515-543$ & & & & & & 563 \\
\hline 457 & $515-543$ & $623-645$ & N.P. & & & & 661 \\
\hline $457-764$ & $515-543$ & $623-645$ & 764 & $676(R)$ & & & 795 \\
\hline $502-821$ & $559-584$ & $672-694$ & 821 & $823(s)$ & & & 894 \\
\hline 315- & $375-400$ & & & & & & 415 \\
\hline 315- & $377-402$ & $498-522$ & & & & & 529 \\
\hline $315-626$ & $377-403$ & $490-516$ & 626 & $?$ & & & 661 \\
\hline $732-$ & $783-810$ & $897-920$ & & & & & 824 \\
\hline $732-$ & $785-805$ & $897-920$ & & & & & 925 \\
\hline $732-1041$ & $788-812$ & $899-924$ & 1041 & & & & 1076 \\
\hline 427- & $492-511$ & & & & & & 525 \\
\hline 427- & $492-511$ & $604-627$ & & & & & 640 \\
\hline $427-721$ & $490-514$ & $604-627$ & 721 & $723.4(\mathrm{~s})$ & & & 741 \\
\hline $87-283$ & $117-140$ & & & & & & 154 \\
\hline $87-283$ & $117-140$ & $237-283$ & & & & & 286 \\
\hline $87-283$ & $117-140$ & $237-273.5$ & 283 & $405(S)$ & & & 420 \\
\hline $399-$ & $466-488$ & & & & & & 505 \\
\hline 399- & $466-488$ & $588-614$ & & & & & 624 \\
\hline $399-733$ & $466-488$ & $588-614$ & 733 & $798(S)$ & & & 808 \\
\hline $455-$ & $523-554$ & & & & & & 559 \\
\hline $455-$ & $523-554$ & $647-677$ & & & & & 708 \\
\hline $455-791$ & $523-554$ & $647-677$ & 791 & $791(S)$ & & & 816 \\
\hline $1204-$ & $1256-1280$ & & & & & & 1318 \\
\hline $1204-$ & $1256-1280$ & $1360-1391$ & & & & & 1398 \\
\hline $1204-1501$ & $1256-1280$ & $1360-1391$ & 1501 & $1501(S)$ & & & 1538 \\
\hline
\end{tabular}


Table 1. Geologic and hydrologic data from test holes drilled at and near the proposed Waste Isolation Pilot Plant site - Continued

\begin{tabular}{|c|c|c|c|c|c|c|c|c|c|c|}
\hline \multirow[b]{2}{*}{$\begin{array}{l}\text { Test } \\
\text { hole }\end{array}$} & \multirow[b]{2}{*}{$\begin{array}{l}\text { Altitude, } \\
\text { in feet } \\
\text { above } \\
\text { sea level }\end{array}$} & \multicolumn{5}{|c|}{ Location } & \multicolumn{4}{|c|}{ Depth of rock } \\
\hline & & Sec. & . T. & R. & $\begin{array}{l}\text { Distance, } \\
\text { from sect }\end{array}$ & $\begin{array}{l}\text { in feet, } \\
\text { tion lines }\end{array}$ & $\begin{array}{l}\text { Surficial } \\
\text { deposits }\end{array}$ & \begin{tabular}{|l|} 
Gatuna \\
Formation
\end{tabular} & $\begin{array}{l}\text { Santa Rosa } \\
\text { Formation }\end{array}$ & $\begin{array}{l}\text { Dewey Lake } \\
\text { Red Beds }\end{array}$ \\
\hline$P-1$ & 3345.1 & 29 & $22 \mathrm{~S}$ & $31 E$ & $328 \mathrm{FSL}$ & $552 \mathrm{FWL}$ & $0-10$ & $10-40$ & N.P. & $40-358$ \\
\hline$P-2$ & 3479.4 & 28 & $22 \mathrm{~S}$ & $31 \mathrm{E}$ & $121 \mathrm{FNL}$ & I7IFEL & $0-18$ & $18-38$ & $38-164$ & $164-690$ \\
\hline$P=3$ & 3382.7 & 20 & 225 & $31 E$ & $104 \mathrm{FSL}$ & $2154 \mathrm{FWL}$ & $0-10$ & $10-41$ & N.P. & $41-468$ \\
\hline$p-4$ & 3443.8 & 28 & $22 \mathrm{~S}$ & $31 \mathrm{E}$ & $149 \mathrm{FSL}$ & $1485 \mathrm{FEL}$ & $0-8$ & N.P. & $8-93$ & $99-609$ \\
\hline$P-5$ & 3470.9 & 17 & $22 \mathrm{~S}$ & $31 \mathrm{E}$ & $186 \mathrm{FSL}$ & I60FEL & $0-13$ & N.P. & $13-146$ & $146-623$ \\
\hline$p-6$ & 3354.1 & 30 & 225 & $31 E$ & $2509 \mathrm{FNL}$ & 195FWL & $0-8$ & $8-18$ & N.P. & $18-357$ \\
\hline$P-7$ & 3332.0 & 5 & 235 & $31 E$ & $514 \mathrm{FNL}$ & $393 \mathrm{FWL}$ & $0-11$ & $11-45$ & N.P. & $45-312$ \\
\hline$P-8$ & 3338.6 & 4 & 235 & $31 E$ & 640FNL & $92 \mathrm{FWL}$ & $0-11$ & $9-39$ & N.P. & $39-391$ \\
\hline$p-q$ & 3411.5 & 33 & $22 \mathrm{~S}$ & $31 E$ & $1493 \mathrm{FSL}$ & $126 \mathrm{FEL}$ & $0-11$ & N.P. & $11-66$ & $66-562$ \\
\hline$P-10$ & 3509.3 & 26 & $22 S$ & $31 \mathrm{E}$ & $2341 \mathrm{FNL}$ & $323 \mathrm{FWL}$ & $0-8$ & N.P. & $8-151$ & $151-686$ \\
\hline$P-11$ & 3503.9 & 23 & $22 \mathrm{~S}$ & $31 \mathrm{E}$ & $156 \mathrm{FNL}$ & $183 \mathrm{FWL}$ & $0-9$ & N.P. & $9-224$ & $224-745$ \\
\hline$P-12$ & 3373.6 & 24 & 225 & $30 E$ & $165 \mathrm{FNL}$ & $198 \mathrm{FEL}$ & $0-8$ & N.P. & N.P. & $8-461$ \\
\hline$P-13$ & 3345.2 & 18 & $22 S$ & $31 \mathrm{E}$ & $110 \mathrm{FNL}$ & $147 \mathrm{FWL}$ & $0-12$ & $12-38$ & N.P. & $38-427$ \\
\hline$P=14$ & 3359.6 & 24 & 225 & $30 E$ & $309 \mathrm{FSL}$ & 613FWL & $0-10$ & $10-42$ & N.P. & $42-387$ \\
\hline$P-15$ & 3309.5 & $31-$ & -225 & $31 E$ & $411 F S L$ & I I9OFL & $0-11$ & $11-32$ & N.P. & $32-231$ \\
\hline$P-16$ & 3317.9 & 5 & 235 & $31 E$ & $939 \mathrm{FSL}$ & $1647 \mathrm{FWL}$ & $0-14$ & $14-32$ & N.P. & $32-316$ \\
\hline$P-17$ & 3335.9 & 4 & 235 & $31 \mathrm{E}$ & $1356 \mathrm{FSL}$ & $398 \mathrm{FWL}$ & $0-14$ & $14-46$ & N.P. & $46-382$ \\
\hline$p-18$ & 3477.2 & 26 & $22 \mathrm{~S}$ & $31 E$ & 139FSL & 733FEL & $0-9$ & N.P. & $9-87$ & $87-628$ \\
\hline$p-19$ & 3545.1 & 23 & 225 & $31 \mathrm{E}$ & $1652 \mathrm{FSL}$ & $2335 \mathrm{FWL}$ & $0-8$ & N.P. & $8-232$ & $232-758$ \\
\hline$P-20$ & 3552.7 & 14 & 225 & $31 E$ & $801 \mathrm{FSL}$ & 79FEL & $0-6$ & N.P. & $6-261$ & $261-780$ \\
\hline$P-21$ & 3509 & 15 & 225 & $31 E$ & $859 \mathrm{FN}$ & 130FEL & $0-8$ & N.P. & $8-225$ & $225-734$ \\
\hline ERDA- 6 & 3540.2 & 35 & 215 & $31 \mathrm{E}$ & $2152 \mathrm{FSL}$ & $910 \mathrm{FEL}$ & $0-17$ & $17-42$ & $42-71$ & $71-536$ \\
\hline ERDA-9 & 3418.86 & 20 & 225 & $31 E$ & $267.23 \mathrm{FSL}$ & $176.74 \mathrm{FEL}$ & $0-15$ & $15-42$ & $42-51$ & $51-538$ \\
\hline ERDA- 10 & 3371.2 & 34 & 235 & $30 \mathrm{E}$ & $200 \mathrm{FNL}$ & $2327 \mathrm{FEL}$ & $0-5$ & $5-151$ & N.P. & $151-366$ \\
\hline$A E C-7$ & 3654.00 & 31 & 215 & $32 \mathrm{E}$ & $2040 \mathrm{FNL}$ & 2040FEL & $0-12$ & N.P. & $12-112$ & $112-662$ \\
\hline$A E C-8$ & 3531.5 & 11 & 225 & $31 E$ & 935FNL & 1979FWL & & $?$ & $31-165$ & $165-660$ \\
\hline
\end{tabular}




\begin{tabular}{|c|c|c|c|c|c|c|c|}
\hline $\begin{array}{l}\text { Rustler } \\
\text { Formation }\end{array}$ & $\begin{array}{l}\text { Magenta } \\
\text { Dolomite } \\
\text { Member of } \\
\text { Rustler } \\
\text { Formation }\end{array}$ & $\begin{array}{l}\text { Culebra } \\
\text { Dolomite } \\
\text { Member of } \\
\text { Rustler } \\
\text { Formation }\end{array}$ & $\begin{array}{l}\text { Top of } \\
\text { Salado } \\
\text { Formation }\end{array}$ & $\begin{array}{l}\text { Top of } \\
\text { salt in } \\
\text { Salado } \\
\text { Formation }\end{array}$ & $\begin{array}{l}\text { Top of } \\
\text { McNutt } \\
\text { potash } \\
\text { zone }\end{array}$ & $\begin{array}{l}\text { Top of } \\
\text { Castile } \\
\text { Formation }\end{array}$ & $\begin{array}{l}\text { Test } \\
\text { hole } \\
\text { depth } \\
\text { in feet }\end{array}$ \\
\hline $358-677$ & $423-448$ & $538-565$ & 677 & $597(R)$ & $1191-1583$ & & 1591.0 \\
\hline $690-1008$ & $748-773$ & $857-883$ & 1008 & $906(R)$ & $1506-1883$ & & 1895.0 \\
\hline $468-786$ & $529-553$ & $642-665$ & 786 & $688(R)$ & $1287-1668$ & & 1676.0 \\
\hline $609-930$ & $662-686$ & $775-802$ & 930 & $826(R)$ & $1446-1853$ & & 1857.0 \\
\hline $623-947$ & $686-711$ & $804-827$ & 947 & $350(R)$ & $1428-1785$ & & 1830.6 \\
\hline $357-659$ & $417-443$ & $537-560$ & 659 & $661(s)$ & $1162-1560$ & & 1573.0 \\
\hline $312-630$ & $373-398$ & $496-522$ & 630 & $562(R)$ & $1155-1566$ & & 1575.0 \\
\hline $391-715$ & $450-474$ & $563-588$ & 715 & $606(R)$ & $1237-1652$ & & 1660.0 \\
\hline $562-881$ & $617-644$ & $734-757$ & 881 & $778(\mathrm{R})$ & $1401-1796$ & & 1796.0 \\
\hline $686-1086$ & $757-781$ & $931-957$ & 1086 & $71 \dot{2}(R)$ & $1594-1983$ & & 2010.8 \\
\hline $745-1058$ & $798-823$ & $912-938$ & 1058 & $958(R)$ & $1550-1917$ & & 1943.1 \\
\hline $461-749$ & $519-543$ & $633-656$ & 749 & $752(S)$ & $1226-1597$ & & 1598.4 \\
\hline $427-721$ & $490-514$ & $604-627$ & 721 & $725(5)$ & $1201-1547$ & & 1577.3 \\
\hline $387-687$ & $453-477$ & $573-595$ & 687 & $695(\mathrm{~s})$ & $1158-1510$ & & 1545.0 \\
\hline $231-542$ & $294-321$ & $413-435$ & 542 & $460(R)$ & $1057-1453$ & & 1465.0 \\
\hline $316-646$ & $376-401$ & $500-523$ & 646 & $552(R)$ & $1174-1585$ & & 1585.0 \\
\hline $382-715$ & $438-463$ & $558-583$ & 715 & $602(R)$ & $1234-1648$ & & 1660.7 \\
\hline $628-1088$ & $704-730$ & $909-938$ & 1088 & $654(R)$ & $1604-2087$ & & 2000.5 \\
\hline $758-1117$ & $614-839$ & $967-997$ & 1117 & $890(R)$ & $\begin{array}{l}1621-2011 \\
\text { projected }\end{array}$ & & 2000.0 \\
\hline $780-1103$ & $839-866$ & $953-979$ & 1103 & $1002(R)$ & $1604-1977$ & & 1994.5 \\
\hline $734-1043$ & $788-812$ & $899-924$ & 1043 & $944(R)$ & $1526-1887$ & & 1916.5 \\
\hline $536-815$ & $595-621$ & $710-735$ & 815 & $815(s)$ & & 2401 & 2775 \\
\hline $538-848$ & $596-620$ & $704-727$ & 848 & $750(s)$ & $1350-1730$ & 2824 & 2876.6 \\
\hline $366-628$ & $366-385$ & $476-504$ & 628 & $678(s)$ & & $\begin{array}{l}2337 \\
3829(0)\end{array}$ & 4418 \\
\hline $662-991$ & $733-759$ & $870-896$ & 991 & $\begin{array}{l}930(R) \\
1000(S)\end{array}$ & & $\begin{array}{l}3004 \\
4522(D)\end{array}$ & 4721 \\
\hline $660-985$ & $715-738$ & $833-859$ & 985 & $985(s)$ & & $\begin{array}{l}2966 \\
4343(0)\end{array}$ & 4910 \\
\hline
\end{tabular}


Table 1. Geologic and hydrologic data from test holes drilled at and near the proposed Waste Isolation Pilot Plant site - Concluded

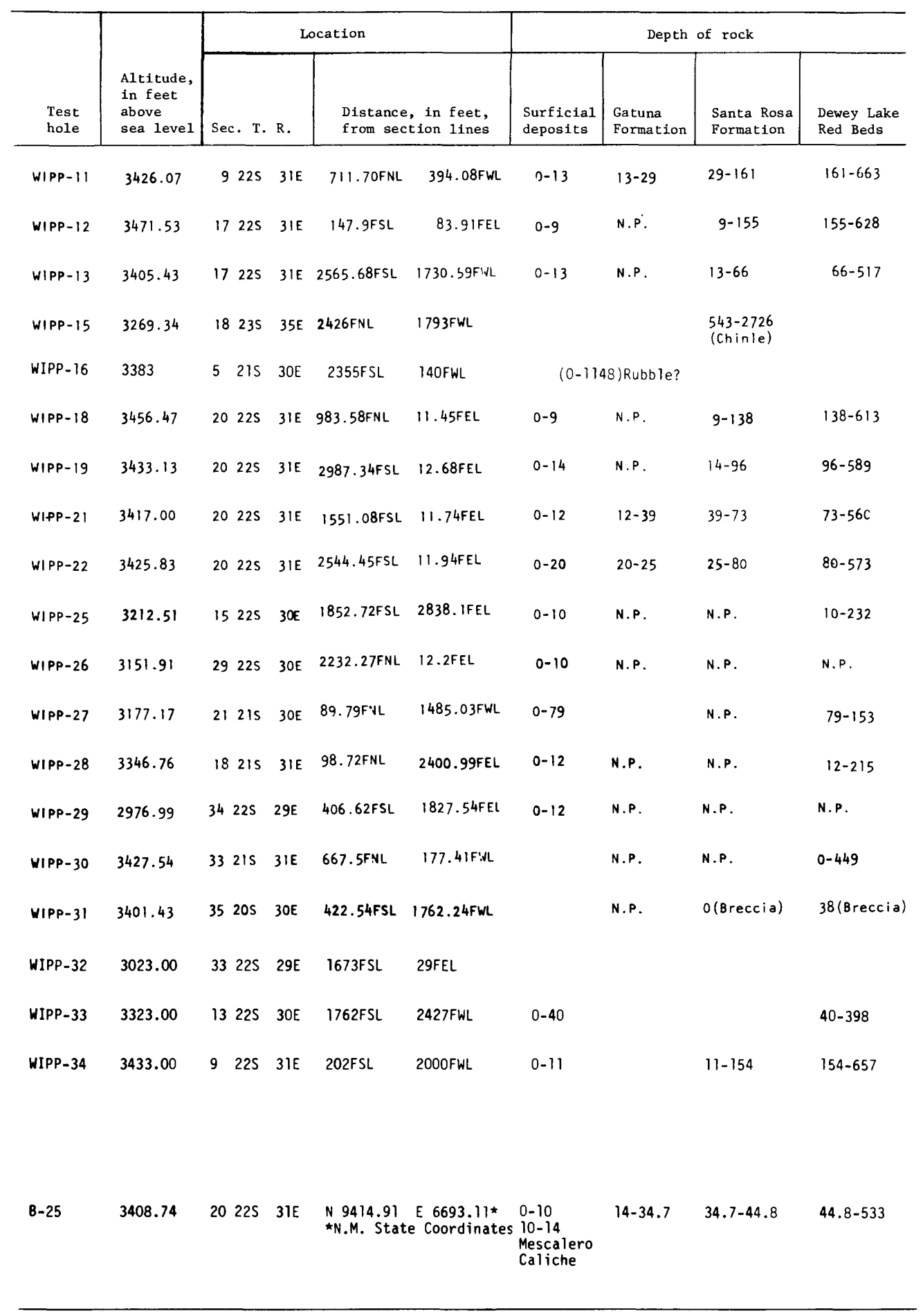




\begin{tabular}{|c|c|c|c|c|c|c|c|}
\hline $\begin{array}{l}\text { Rustler } \\
\text { Formation }\end{array}$ & $\begin{array}{l}\text { Magenta } \\
\text { Dolomite } \\
\text { Member of } \\
\text { Rustler } \\
\text { Formation }\end{array}$ & $\begin{array}{l}\text { Culebra } \\
\text { Dolomite } \\
\text { Member of } \\
\text { Rustler } \\
\text { Formation }\end{array}$ & $\begin{array}{l}\text { Top of } \\
\text { Salado } \\
\text { Formation }\end{array}$ & $\begin{array}{l}\text { Top of } \\
\text { salt in } \\
\text { Salado } \\
\text { Formation }\end{array}$ & $\begin{array}{l}\text { Top of } \\
\text { McNutt } \\
\text { potash } \\
\text { zone }\end{array}$ & $\begin{array}{l}\text { Top of } \\
\text { Castile } \\
\text { Formation }\end{array}$ & $\begin{array}{l}\text { Test } \\
\text { hole } \\
\text { depth } \\
\text { in feet }\end{array}$ \\
\hline $663-951$ & $727-750$ & $844-867$ & 951 & $951(S)$ & & 2330 & 3580.6 \\
\hline $628-955$ & $690-715$ & $810-835$ & 955 & $\begin{array}{l}857(R) \\
955(S)\end{array}$ & & 2727 & 2777.8 \\
\hline $517-844$ & $564-583$ & $701-724$ & 844 & $\begin{array}{l}774(\mathrm{R}) \\
918(\mathrm{~S})\end{array}$ & & & 1025 \\
\hline & & & & & & & 810.5 \\
\hline $1148-1300+$ & 1189-1199 & $1153-1176$ & & & & & 1300 \\
\hline $613-928$ & $672-696$ & $786-808$ & 928 & $\begin{array}{l}829(\mathrm{R}) \\
928(\mathrm{~S})\end{array}$ & & & 1060 \\
\hline $589-894$ & $647-672$ & $756-777$ & 894 & $894(s)$ & & & 1038 \\
\hline $560-868$ & $618-641$ & $729-753$ & 868 & $\begin{array}{l}770(R) \\
868(S)\end{array}$ & & & 1045 \\
\hline $573-883$ & $630-654$ & $742-764$ & 883 & $\begin{array}{l}785(R) \\
884(S)\end{array}$ & & & 1450 \\
\hline $232-565$ & $302-328$ & $447-472$ & 565 & $600(s)$ & & & 655 \\
\hline $10-309$ & $70-99$ & $186-209$ & 309 & $320(s)$ & & & 503 \\
\hline $153-416$ & $176-194$ & $292-318$ & 416 & $508(5)$ & & & 592 \\
\hline $215-531.0$ & $285-310$ & $420-446$ & 531 & 589 (s) & & & 801 \\
\hline N.P. & N.P. & $12-42$ & 143 & $251(S)$ & & & 376 \\
\hline $449-749$ & $513-537$ & $63 l-654$ & 749 & $749(5)$ & & & 913 \\
\hline $750($ Breccia $)$ & \multicolumn{2}{|l|}{1981 (Breccia) } & N.P. & & & & 1981 \\
\hline $0-166$ & $19-36$ & $61-90$ & $166-390$ & & & & 390 \\
\hline $398-675$ & $449-468$ & $550-578$ & $657-840$ & & & & 840 \\
\hline $657-973$ & $718-741$ & $834-860$ & $973-1820+$ & & & & 1820 \\
\hline $533-842.9$ & $592.7-617$ & $704 \cdot 1-728$ & 842.9 & & & & 901 \\
\hline
\end{tabular}




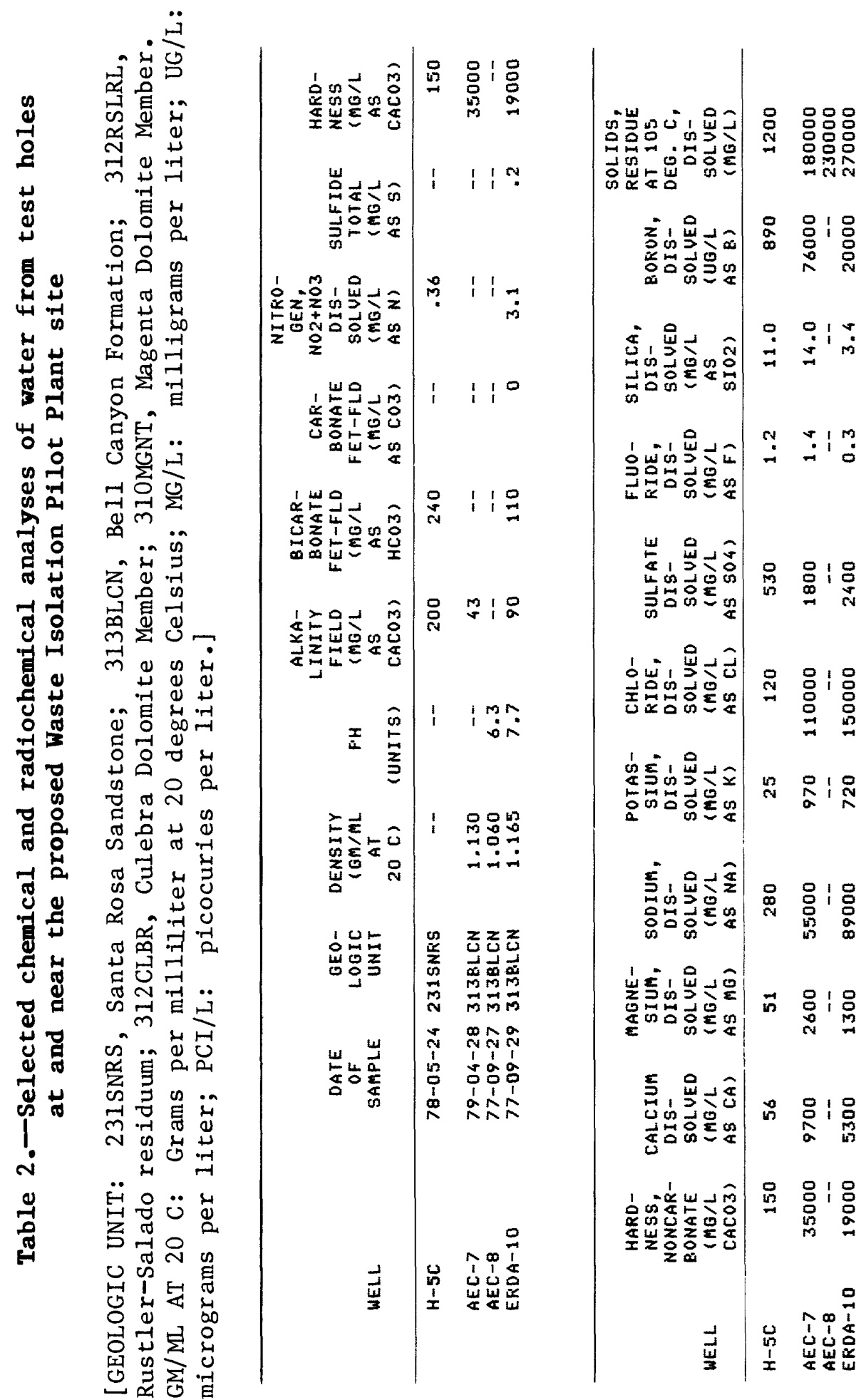




\begin{tabular}{|c|c|}
\hline 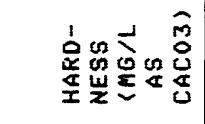 & 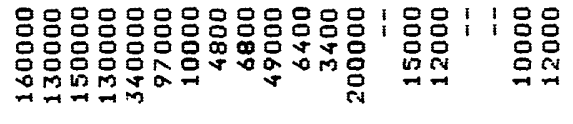 \\
\hline 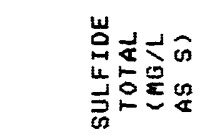 & 11111110111109111111 \\
\hline 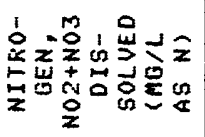 & 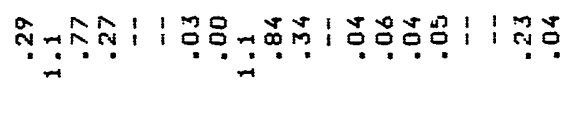 \\
\hline 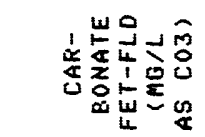 & $000011111: 101111111111$ \\
\hline 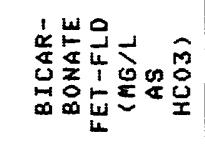 & 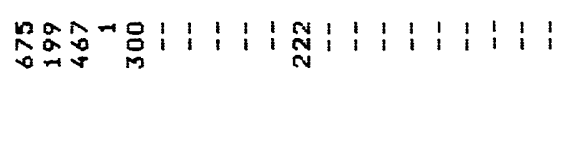 \\
\hline 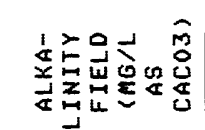 & 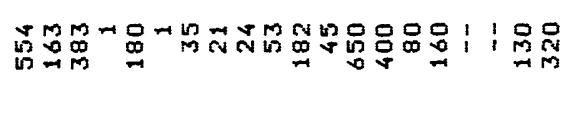 \\
\hline$\frac{5}{2} \underset{5}{z}$ & 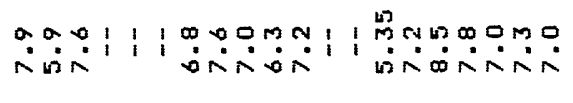 \\
\hline 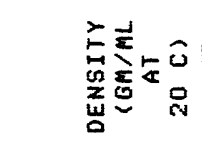 & 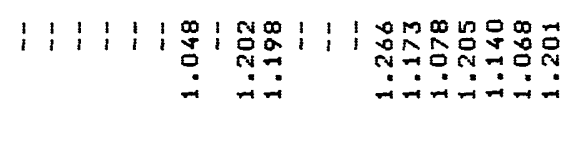 \\
\hline 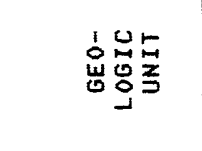 & 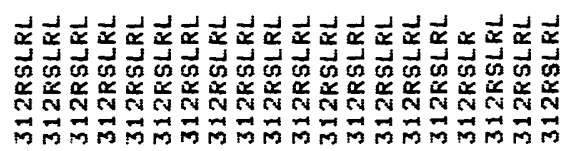 \\
\hline$\underset{5}{w}$ & 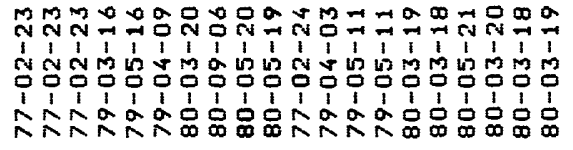 \\
\hline 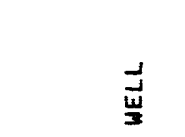 & 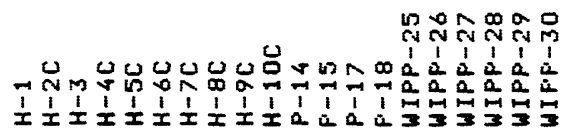 \\
\hline
\end{tabular}

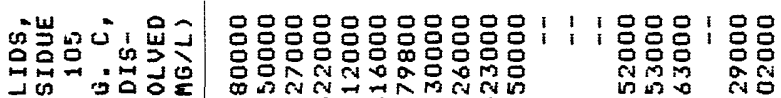

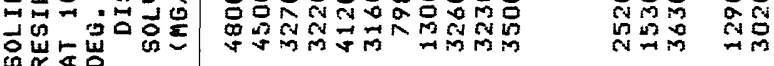

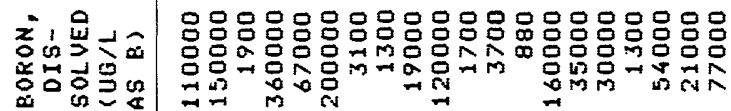

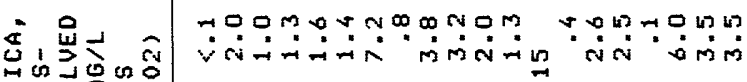

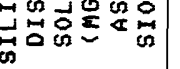

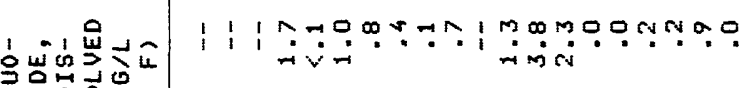

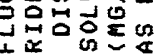

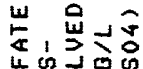

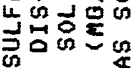

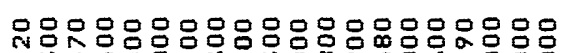

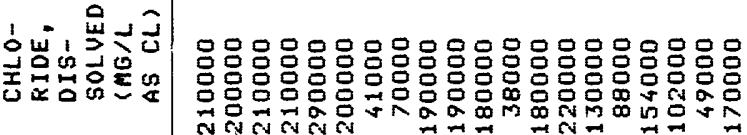

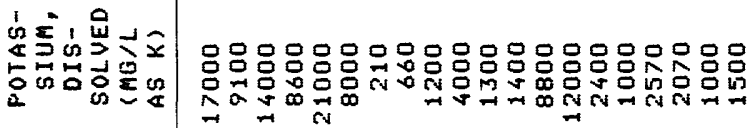

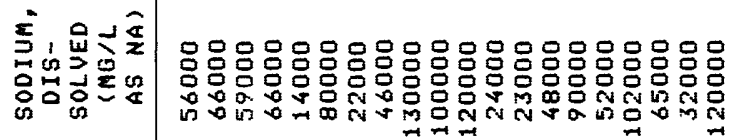

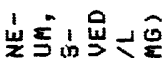

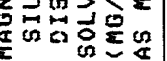

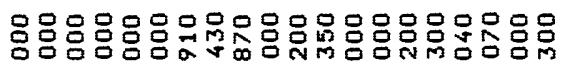

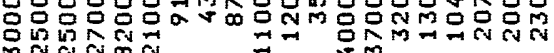

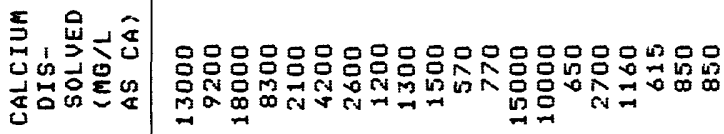

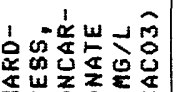

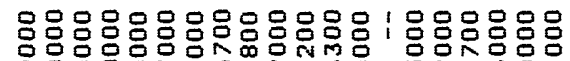

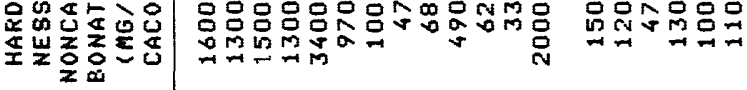

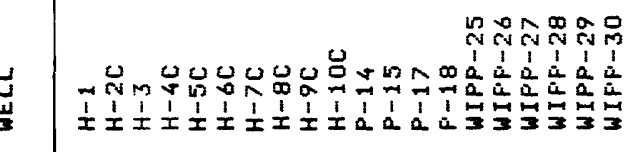




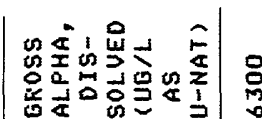

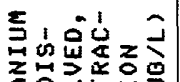

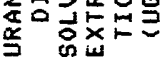

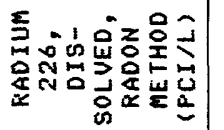

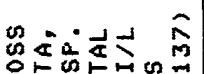

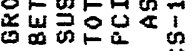

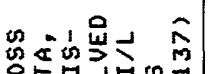

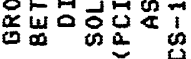

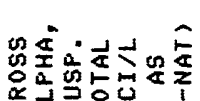

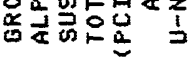

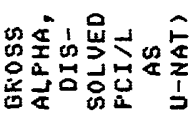

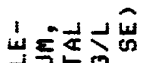

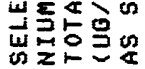

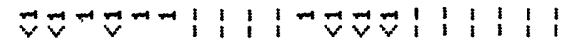

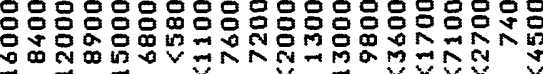

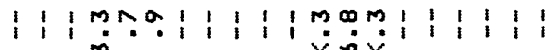

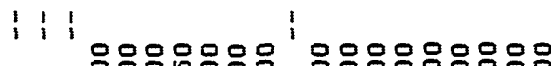

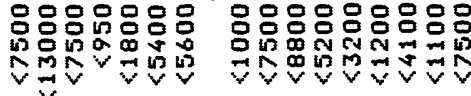

题高

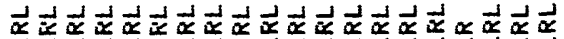

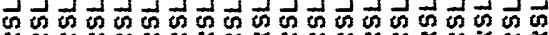

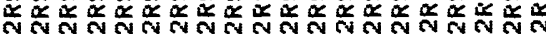

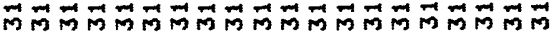

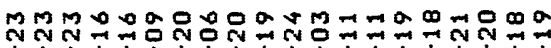
岩莙崖

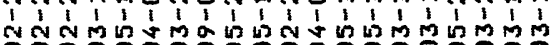

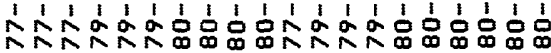

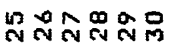

T)

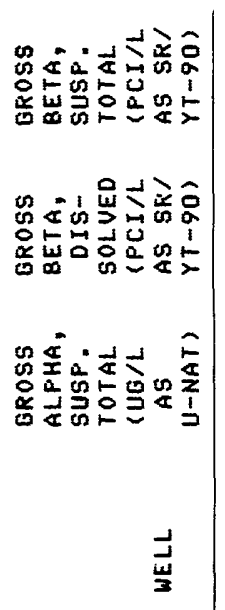

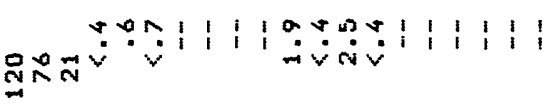

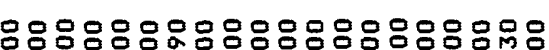

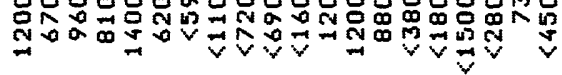

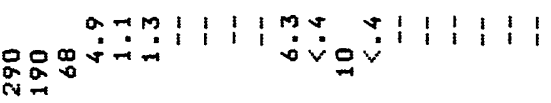

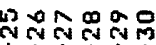

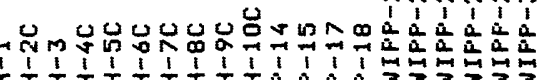




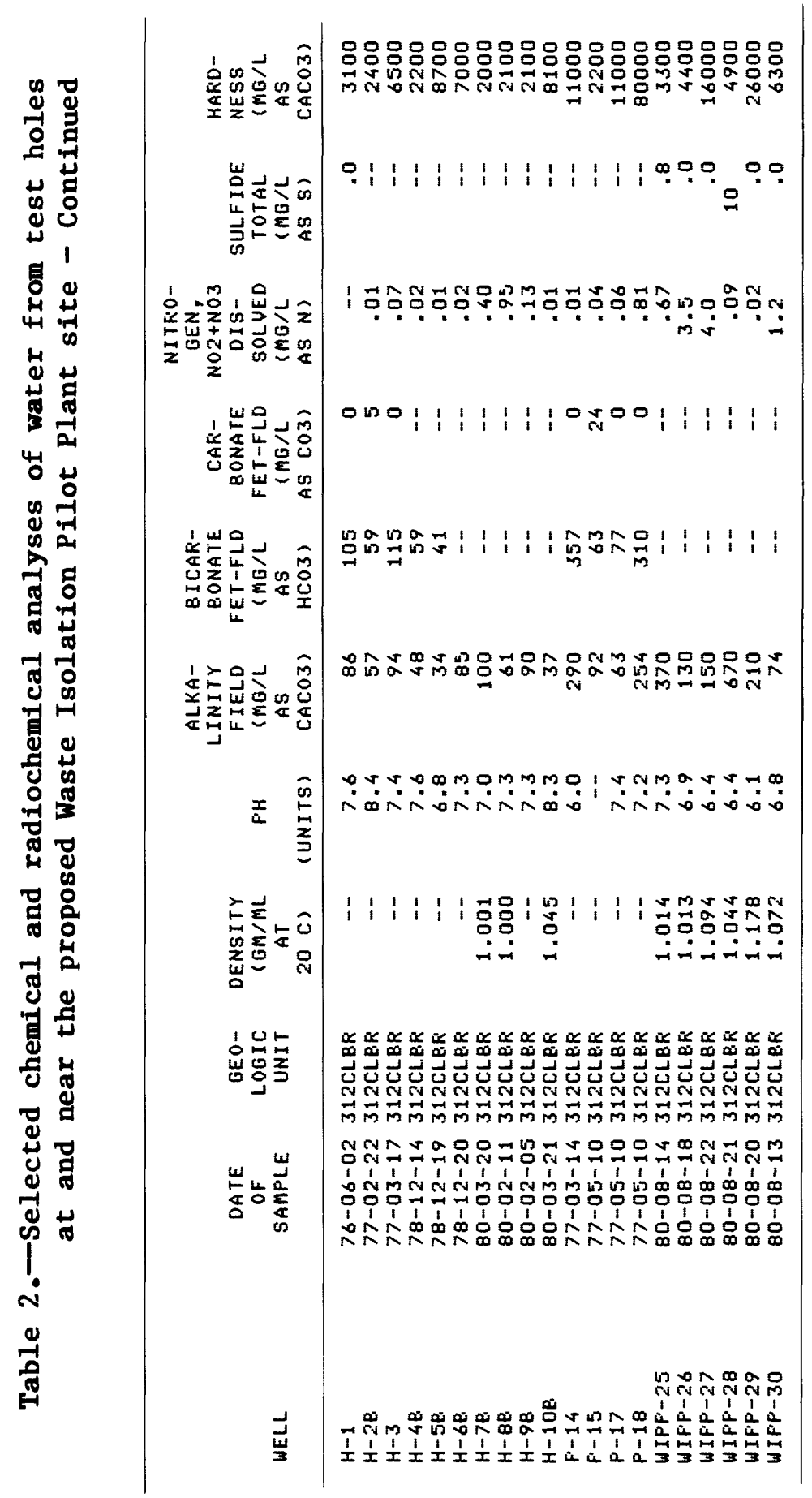

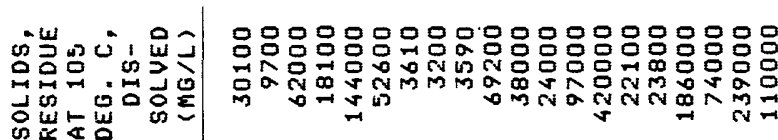

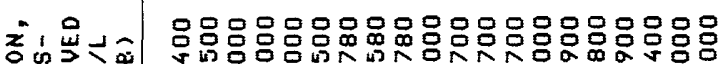

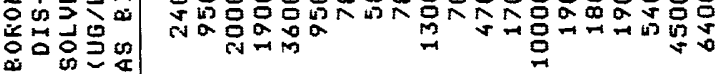

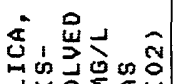

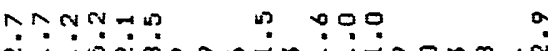

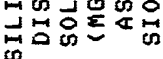

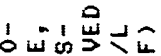

vich

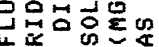

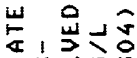

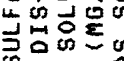

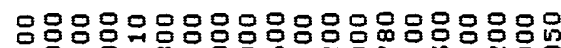

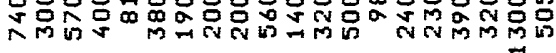

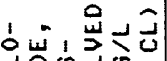

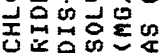

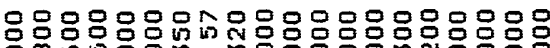

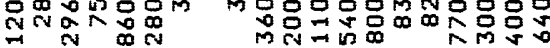

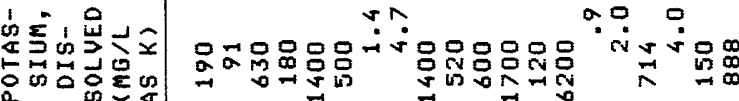

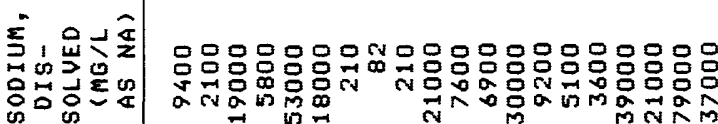

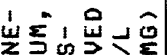

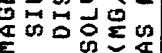

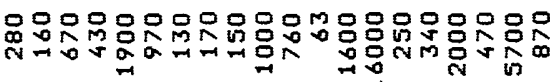

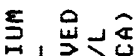

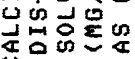

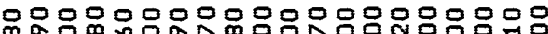

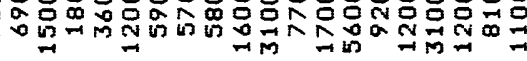

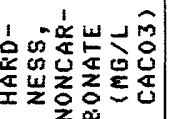

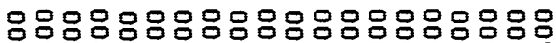

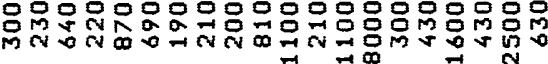

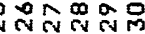
岁 


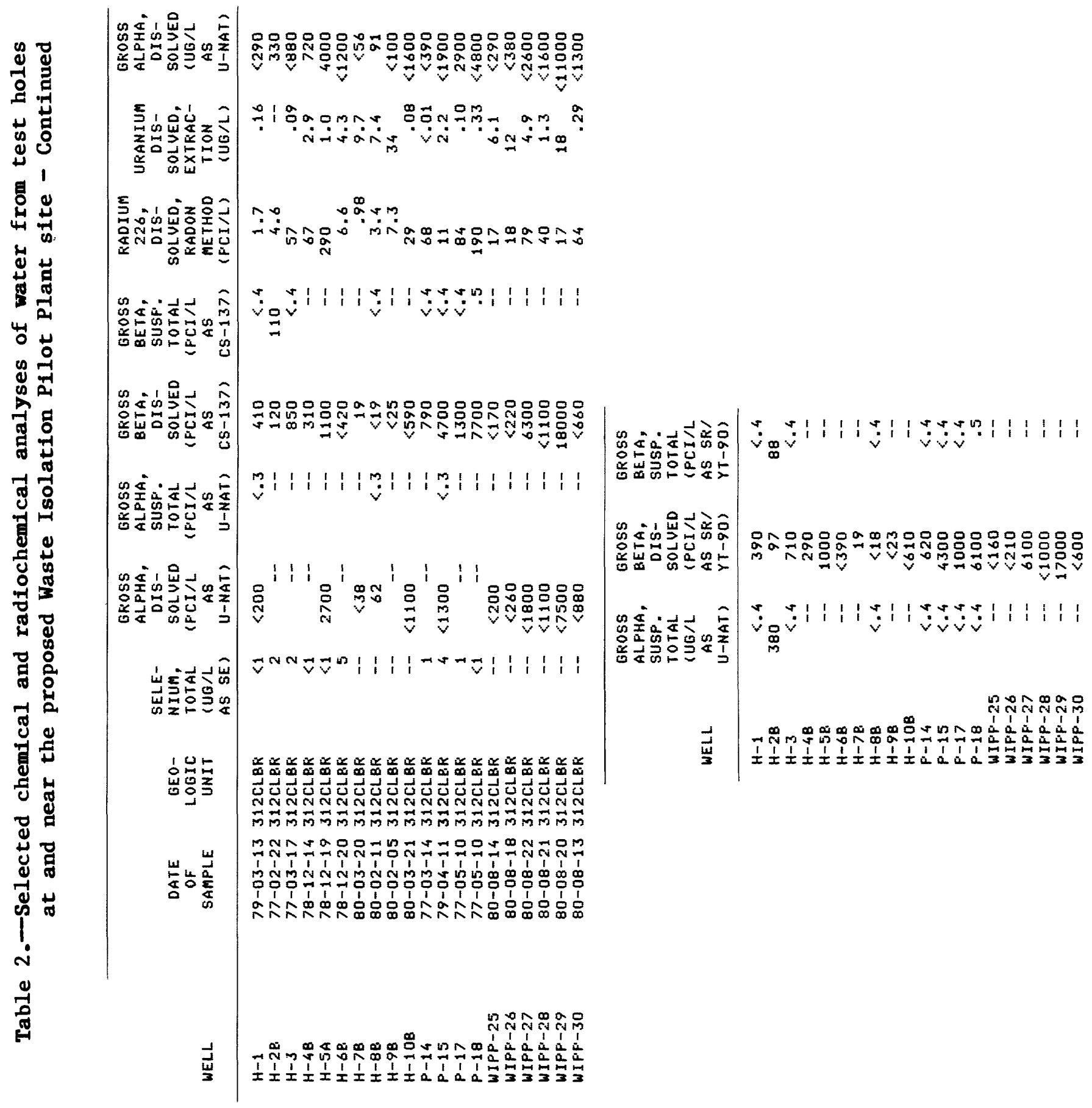




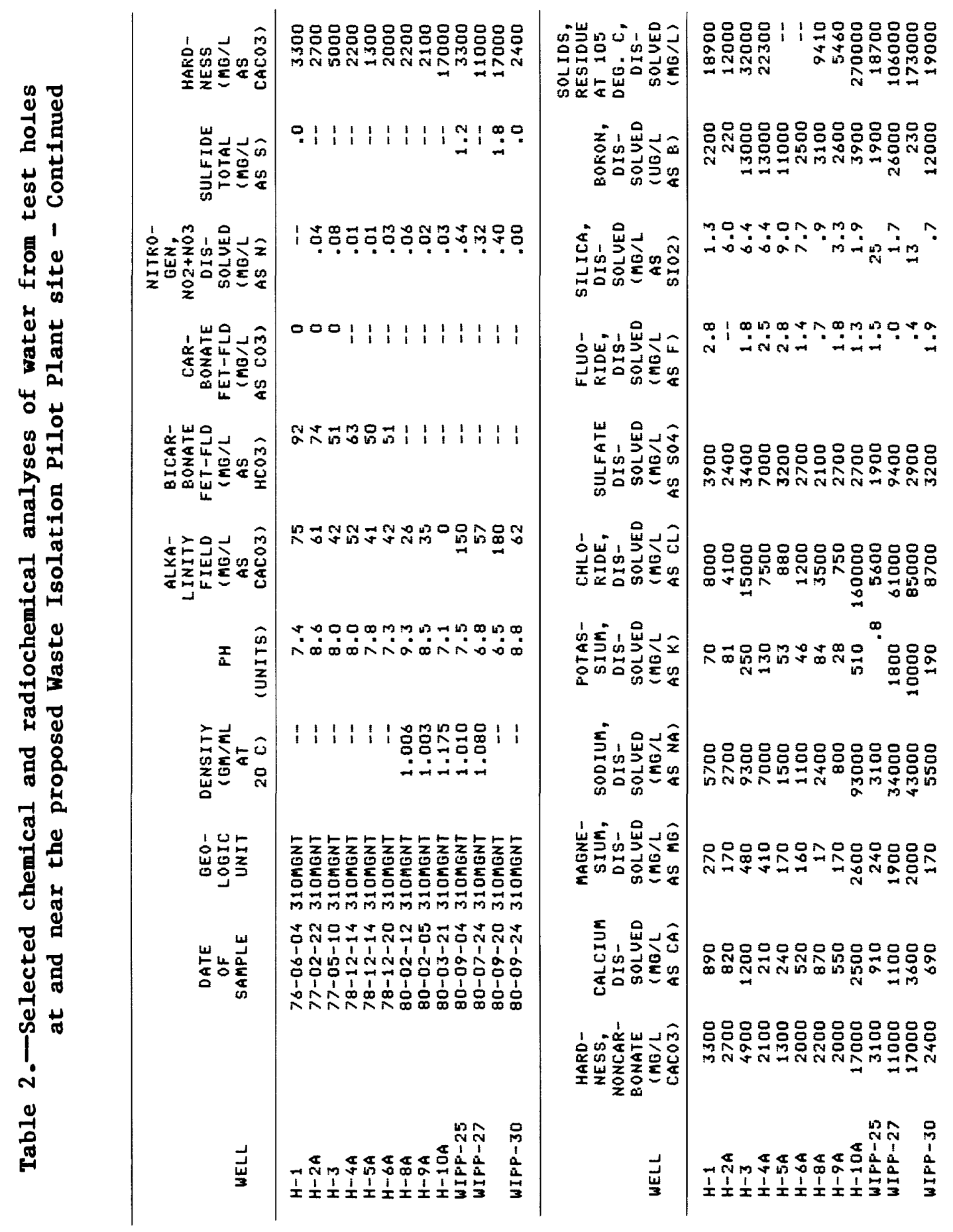




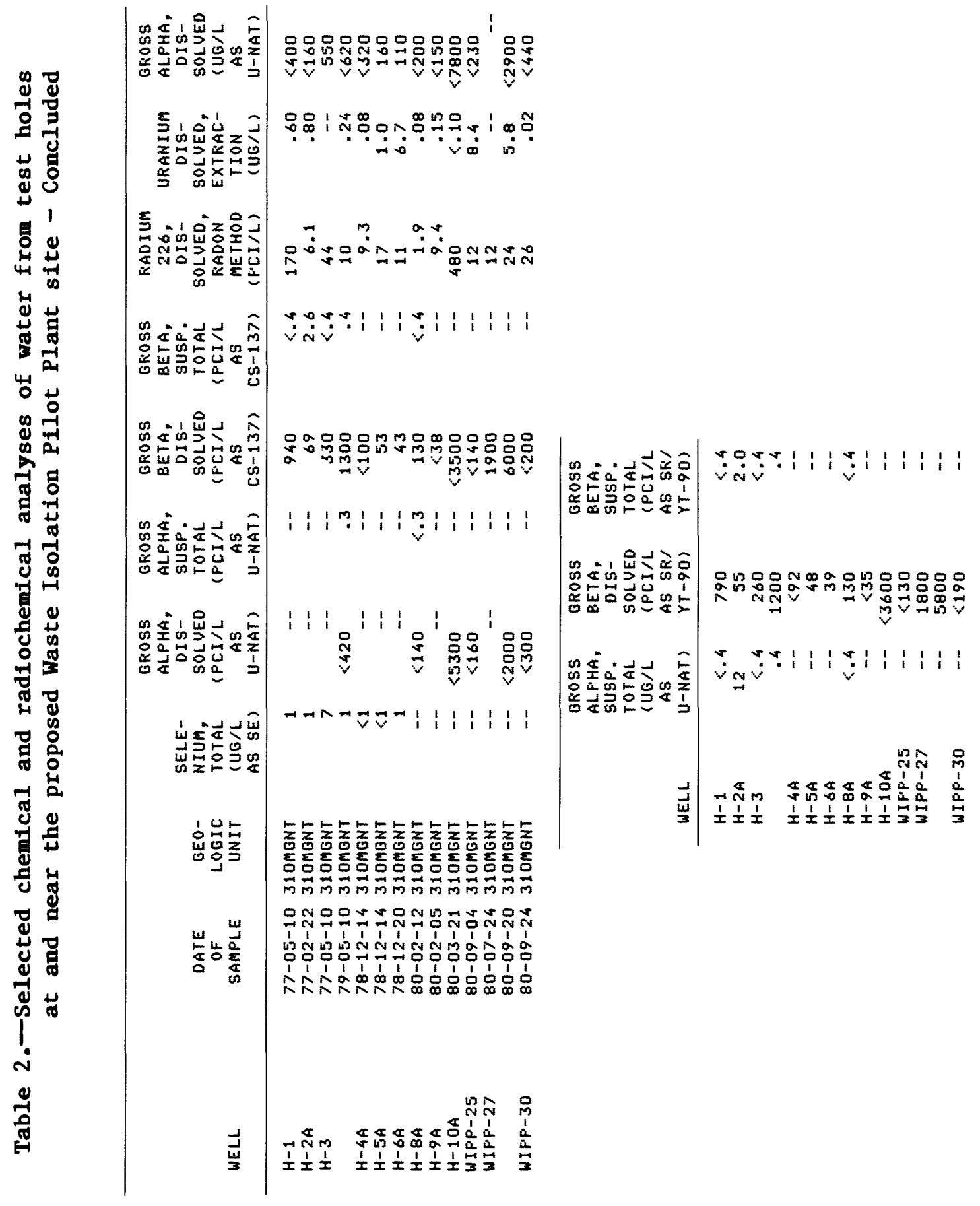




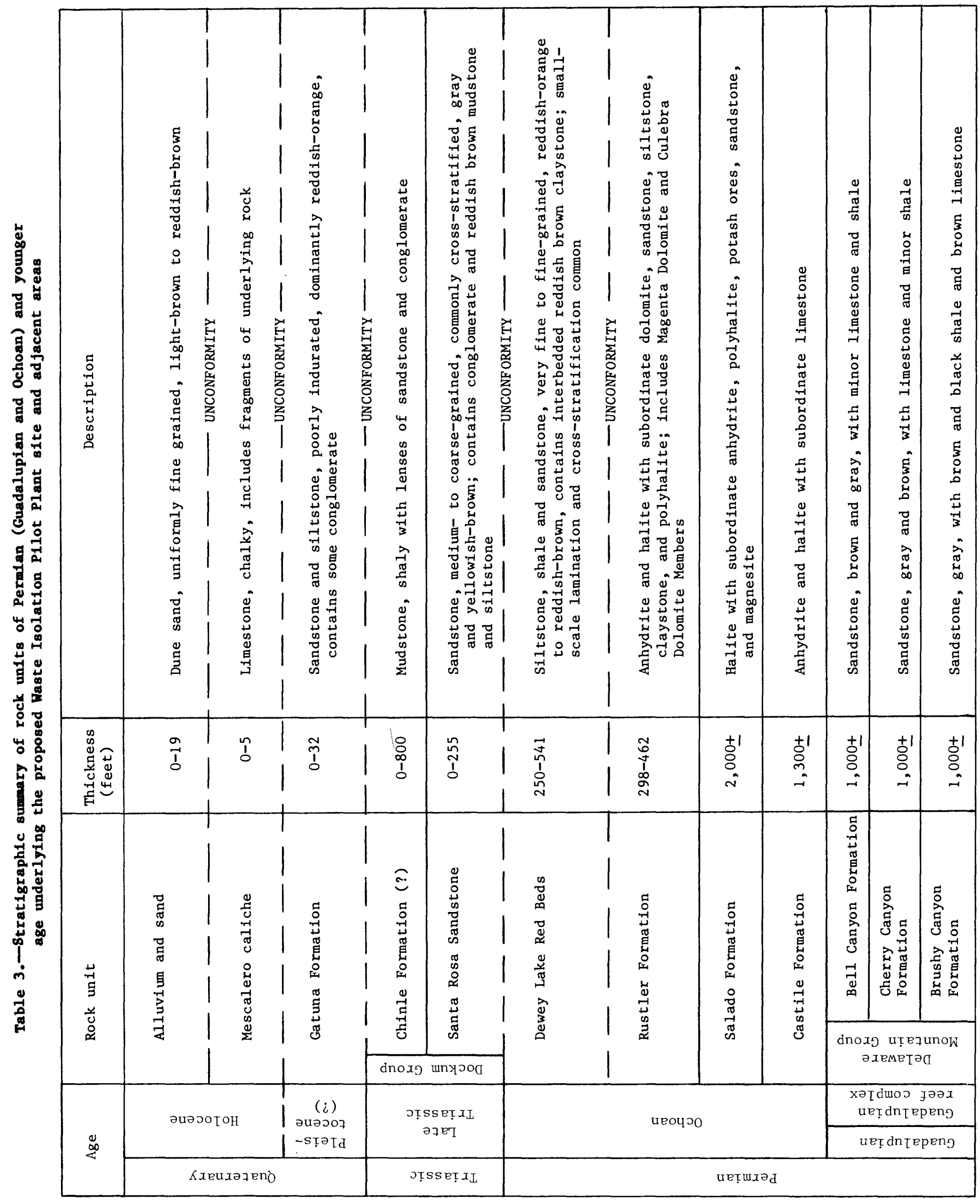




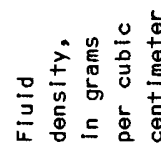

$\stackrel{\circ}{\stackrel{\circ}{=}}$

$\stackrel{9}{\stackrel{9}{-}} \stackrel{\circ}{-}$

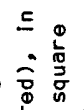

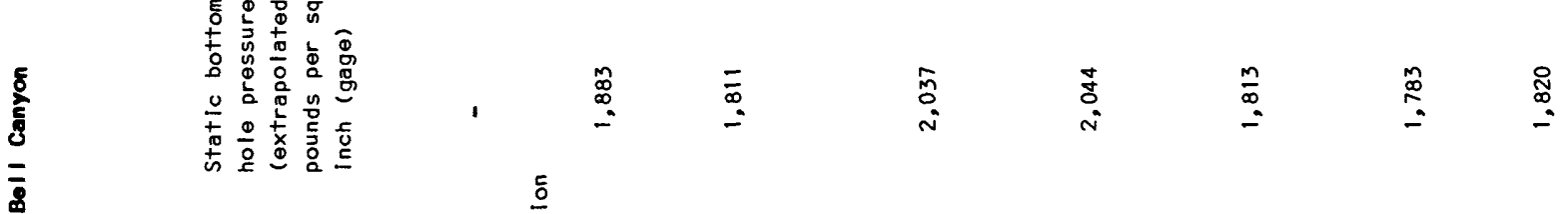

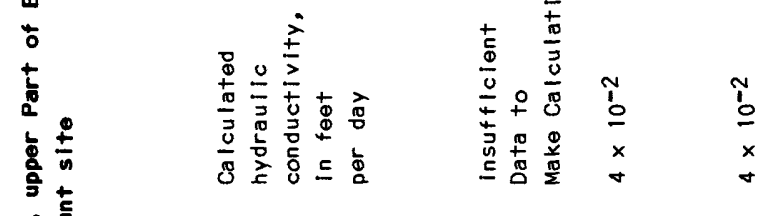

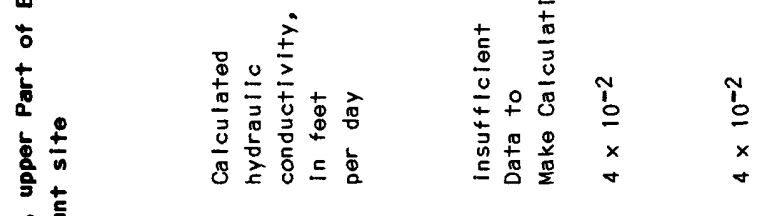

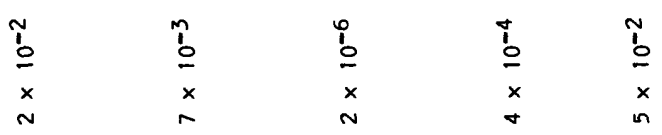

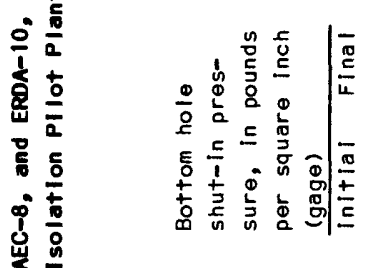

พูก ก

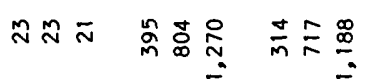

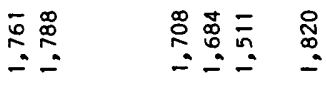

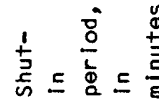

兑尊 8 으

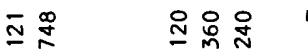

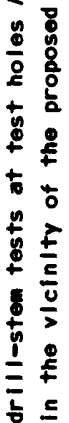

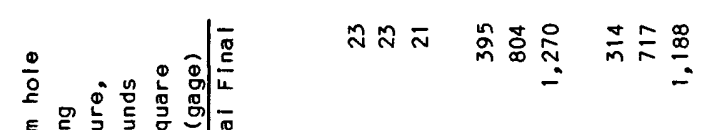

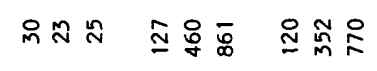

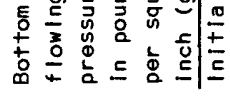

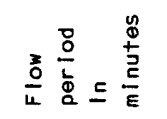

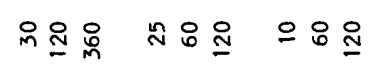

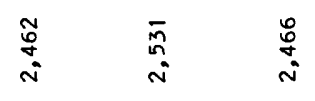

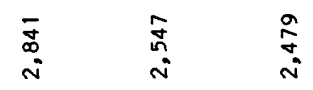

离京

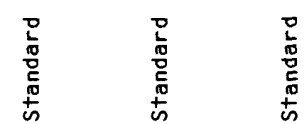

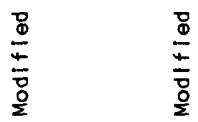

$\underline{\infty} \quad \stackrel{\infty}{m} \frac{\square}{N}$

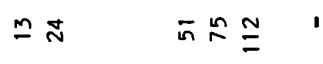

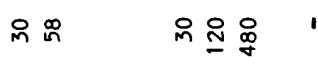

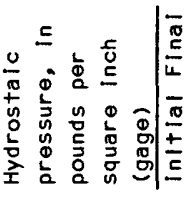

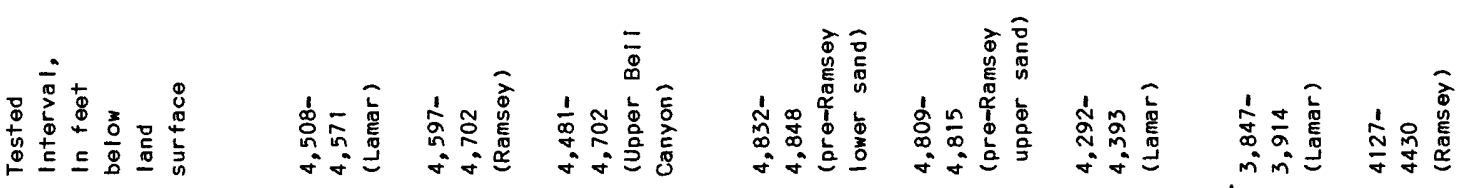

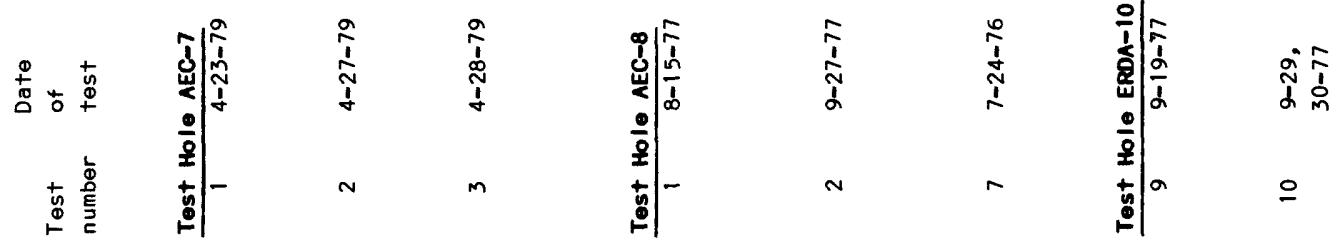




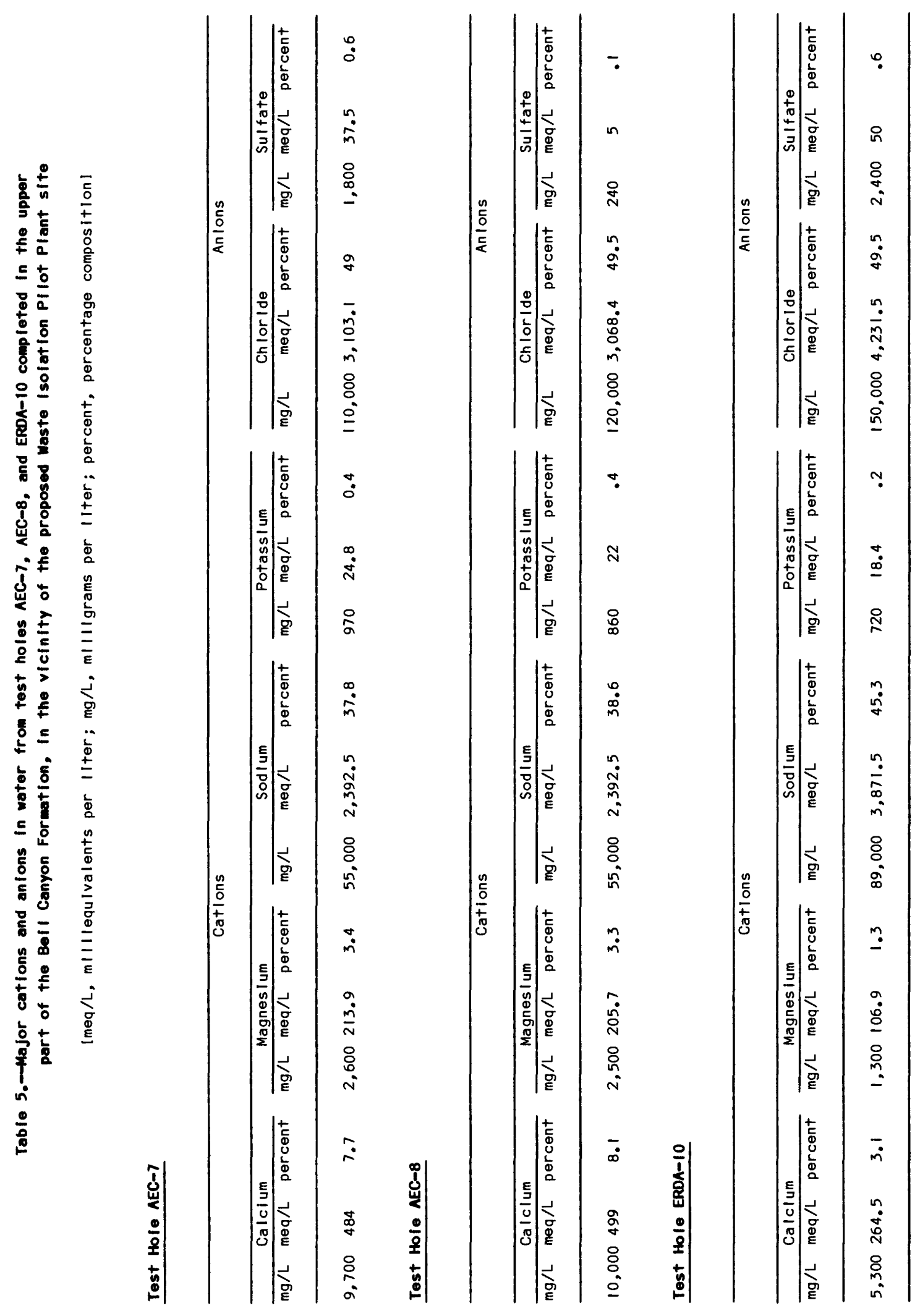


Table 6. - Measured and density-corrected water levels in selected test holes completed In the Rustler-Salado contact residuun at and near the proposed waste Isolation Pilot Plant site

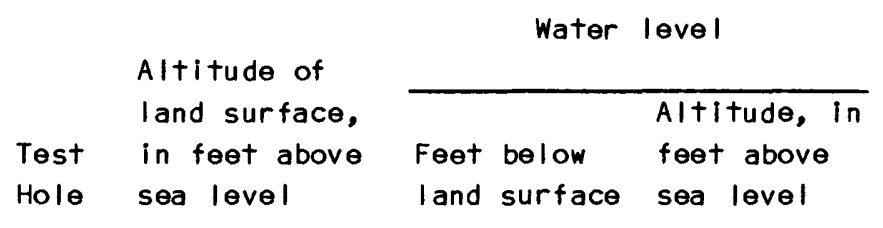

Density, in grams per cubic centimeter
Freshwater equivalent corrected water level

\begin{tabular}{ll}
\hline & Altitude, in \\
Feet below & feet above \\
land surface & sea level
\end{tabular}

$\begin{array}{lllllll}H-2 c & 3,377.7 & 343 & 3,035 & 1.225 & 258 & 3,120 \\ H-4 c & 3,333.5 & 411 & 2,923 & 1.215 & 365 & 2,969 \\ \text { H-6c } & 3,347.9 & 410.5 & 2,937 & 1.210 & 345 & 3,003 \\ \text { H-7c } & 3,163.5 & 205.7 & 2,958 & 1.048 & 197 & 2,967 \\ \text { H-8c } & 3,433.0 & 463 & 2,970 & 1.129 & 421 & 3,012 \\ \text { P-14 } & 3,359.6 & 389 & 2,971 & 1.126 & 351 & 3,009 \\ \text { P-15 } & 3,309.5 & 313.9 & 2,996 & 1.160 & 278 & 3,032 \\ \text { P-17 } & 3,335.9 & 365 & 2,971 & 1.193 & 297 & 3,039 \\ W-25 & 3,212.5 & 238.4 & 2,974 & 1.093 & 206 & 3,007 \\ W-26 & 3,151.9 & 191.7 & 2,960 & 1.189 & 168 & 2,984 \\ W-27 & 3,177.2 & 192 & 2,985 & 1.207 & 126 & 3,051 \\ W-28 & 3,346.8 & 303 & 3,044 & 1.152 & 259 & 3,088 \\ W-29 & 2,977 & 17.6 & 2,959 & 1.129 & 12 & 2,989 \\ W-30 & 3,427.5 & 307 & 3,121 & 1.204 & 218 & 3,210\end{array}$


Table 7.--Values of transmissivity and storage coefflclent for water-bearing zones In the Rustler Formation penetrated by seiected test holes at and near the proposed Waste isolation Pilot Piant site

[Transmissivity is expressed in feet squared per day]

\begin{tabular}{|c|c|c|c|c|c|c|}
\hline \multirow{2}{*}{$\begin{array}{l}\text { Test } \\
\text { hole }\end{array}$} & \multicolumn{2}{|c|}{$\begin{array}{c}\text { Magenta Doloinite } \\
\text { Member }\end{array}$} & \multicolumn{2}{|c|}{$\begin{array}{c}\text { Culebra Dolomite } \\
\text { Member }\end{array}$} & \multicolumn{2}{|c|}{$\begin{array}{c}\text { Rust ler-Salado } \\
\text { Contact } \\
\text { Residuum } \\
\end{array}$} \\
\hline & Transmissivity & Storage & Transmissivity & Storage & Transmissivity & Storage \\
\hline $\mathrm{H}-1$ & 0.05 & - & 0.07 & $10^{-4}$ & 0.0003 & - \\
\hline$H-2 A$ & .01 & $10^{-4}$ & & & & \\
\hline $\mathrm{H}-2 \mathrm{~B}$ & & & 0.4 & $10^{-9}$ & & \\
\hline $\mathrm{H}-2 \mathrm{C}$ & & & & & 0.0001 & - \\
\hline $\mathrm{H}-3$ & .1 & $10^{-5}$ & 19.0 & - & 0.0003 & $10^{-4}$ \\
\hline$H-4 A$ & .06 & $10^{-6}$ & & & & \\
\hline$H-4 B$ & & & 0.9 & $10^{-9}$ & & \\
\hline $\mathrm{H}-4 \mathrm{C}$ & & & & & 0.0006 & $10^{-4}$ \\
\hline$H-5 A$ & .1 & $10^{-5}$ & & & & \\
\hline$H-5 B$ & & & 0.2 & $10^{-5}$ & & \\
\hline $\mathrm{H}-5 \mathrm{C}$ & & & & & .00003 & $10^{-3}$ \\
\hline$H-6 A$ & .3 & $10^{-5}$ & & & & \\
\hline$H-6 B$ & & & 73.0 & - & & \\
\hline $\mathrm{H}-6 \mathrm{C}$ & & & & & .003 & $10^{-6}$ \\
\hline$H-7 A$ & Unsaturated & - & & & & \\
\hline$H-7 B$ & & & $1000+$ & - & & \\
\hline $\mathrm{H}-7 \mathrm{C}$ & & & & & 0.73 & - \\
\hline$H-8 A$ & .006 & $10^{-5}$ & & & & \\
\hline$H-8 B$ & & & 16.0 & - & & \\
\hline $\mathrm{H}-8 \mathrm{C}$ & & & & & 0.003 & - \\
\hline$H-9 A$ & 1.0 & $10^{-9}$ & & & & \\
\hline$H-9 B$ & & & 231 & - & & \\
\hline $\mathrm{H}-9 \mathrm{C}$ & & & & & 0.0002 & - \\
\hline$H-10 A$ & 0.01 & $10^{-3}$ & & & & \\
\hline$H-10 B$ & & & 0.07 & $10^{-4}$ & & \\
\hline $\mathrm{H}-10 \mathrm{C}$ & & & & & 0.00009 & - \\
\hline$P-14$ & & & 140 & - & 0.05 & - \\
\hline$P-15$ & & & 0.07 & $10^{-4}$ & 0.0004 & - \\
\hline$P-17$ & & & 1.0 & $10^{-6}$ & 0.0002 & $10^{-4}$ \\
\hline$P-18$ & & & 0.001 & - & 0.00003 & $10^{-5}$ \\
\hline$w-25$ & 375 & - & 270 & - & 5.0 & $10^{-3}$ \\
\hline$w-26$ & Unsaturated & - & 1250 & - & 0.4 & - \\
\hline$W-27$ & 53 & - & 650 & - & 0.0002 & - \\
\hline$W-28$ & Unsaturated & - & 18 & - & 0.87 & - \\
\hline$w-29$ & Not pres & ent & 1000 & - & 8 & - \\
\hline$w-30$ & 0.004 & - & 0.3 & $10^{-4}$ & 0.2 & $10^{-4}$ \\
\hline
\end{tabular}




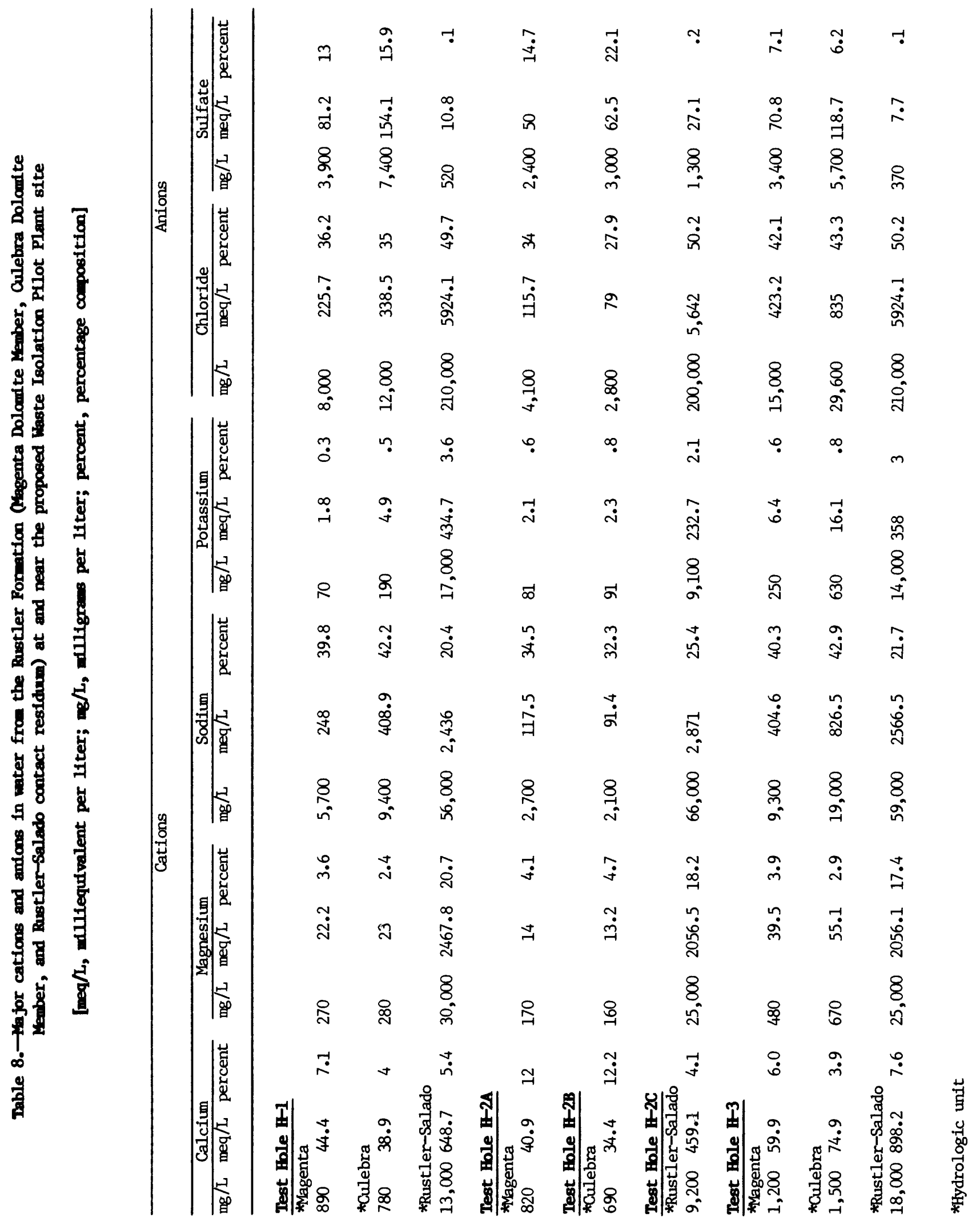




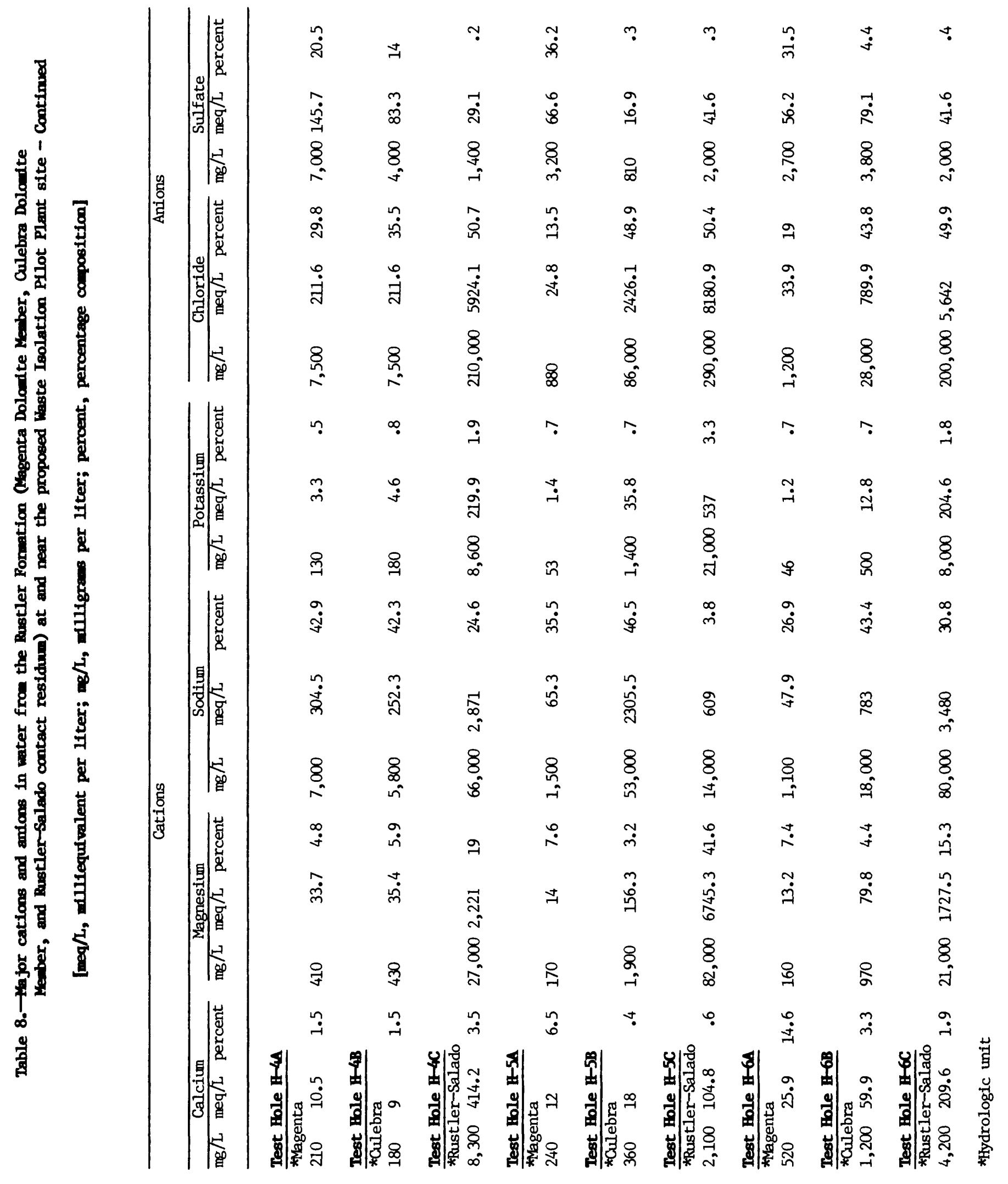




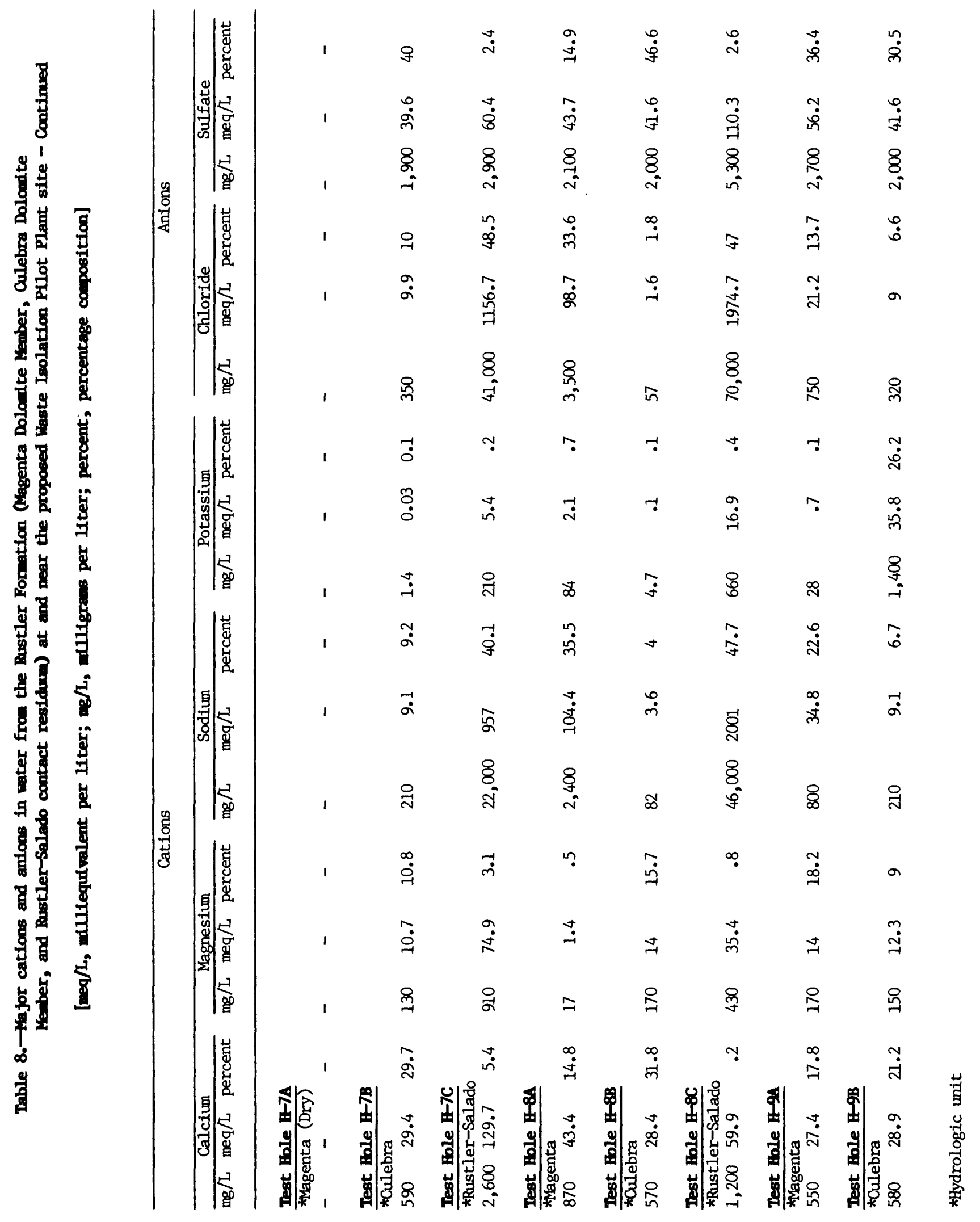




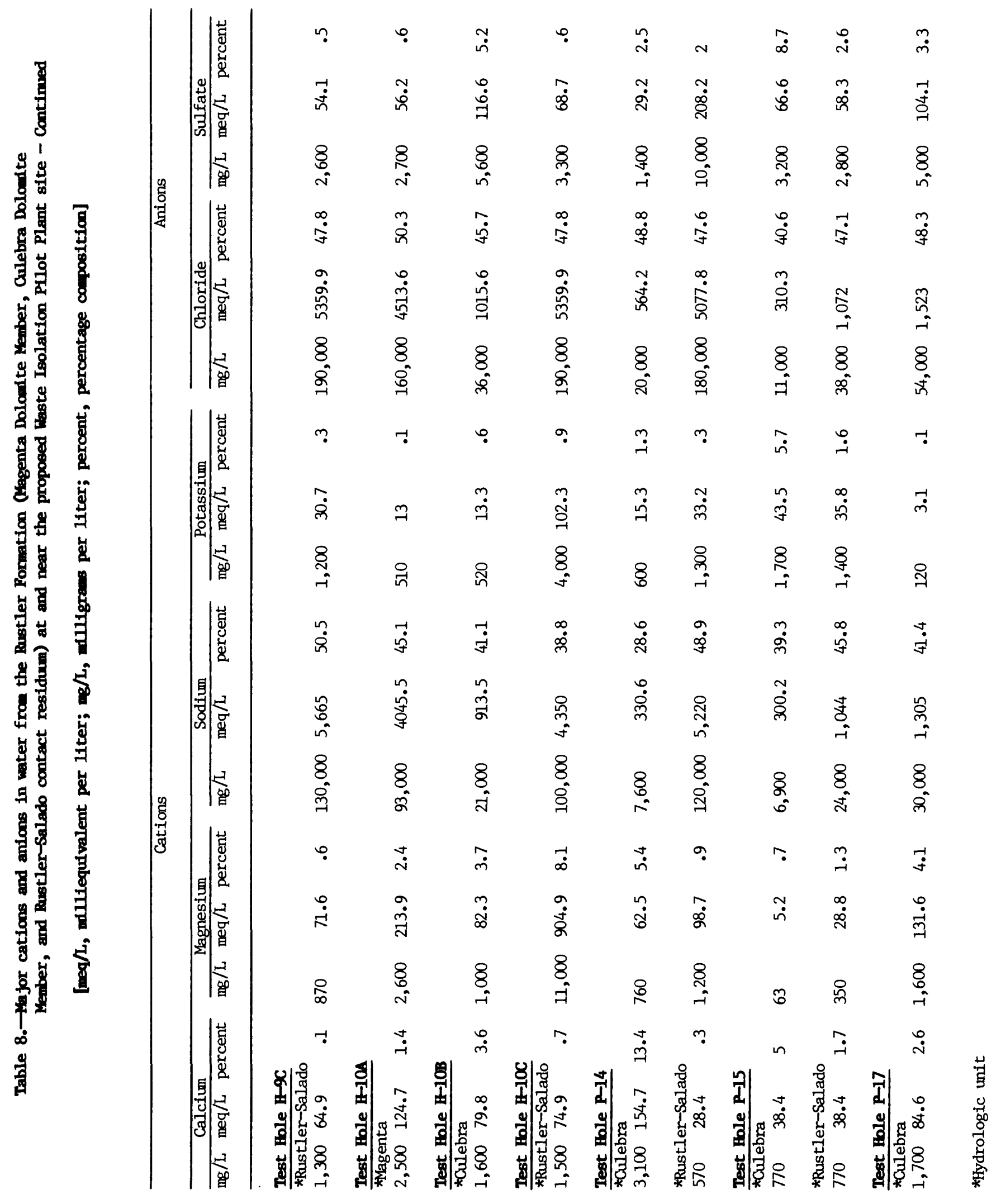



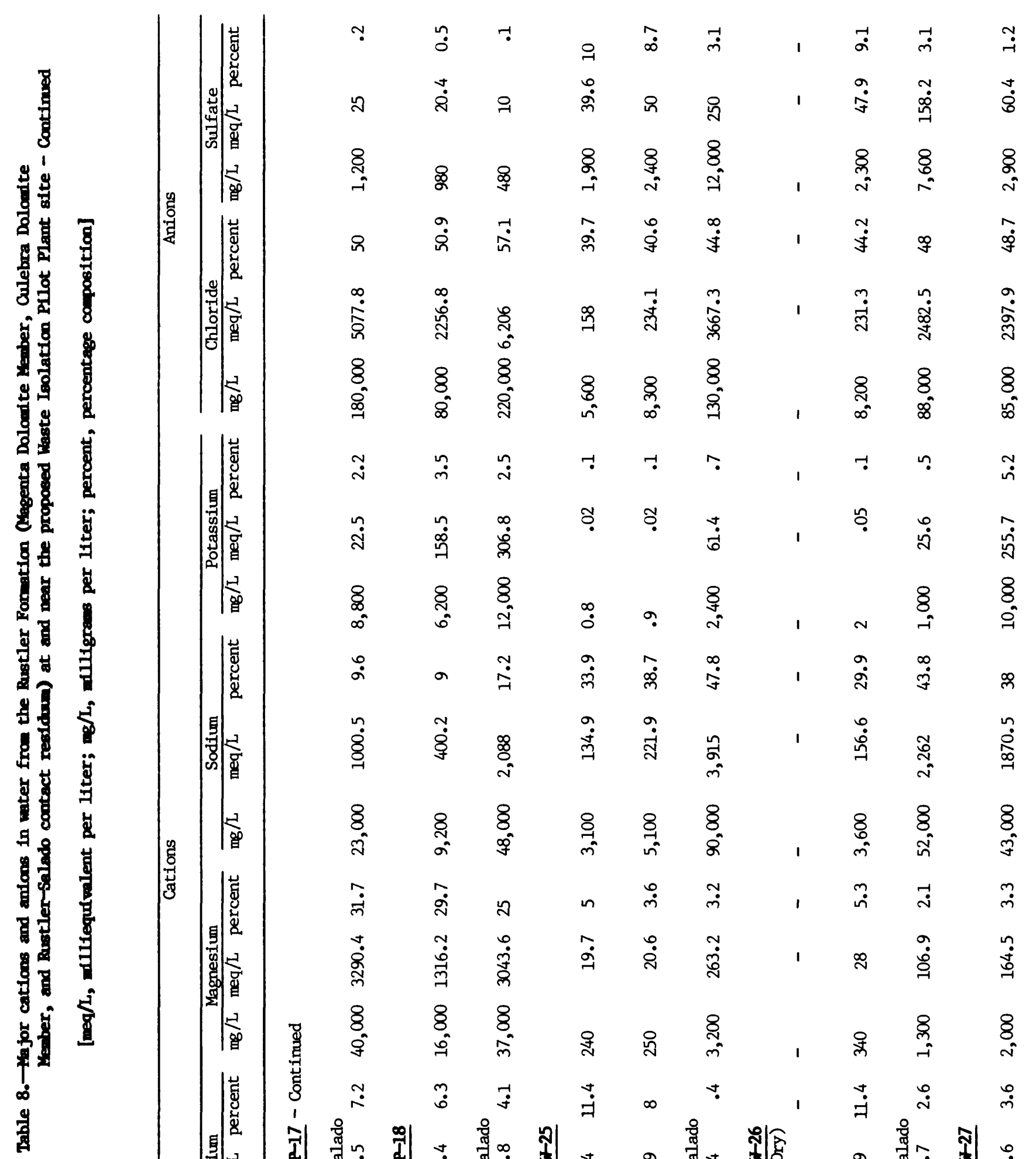

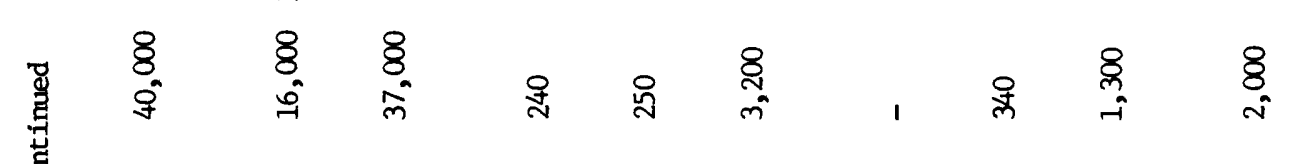

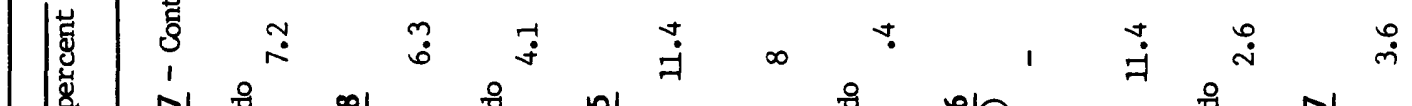

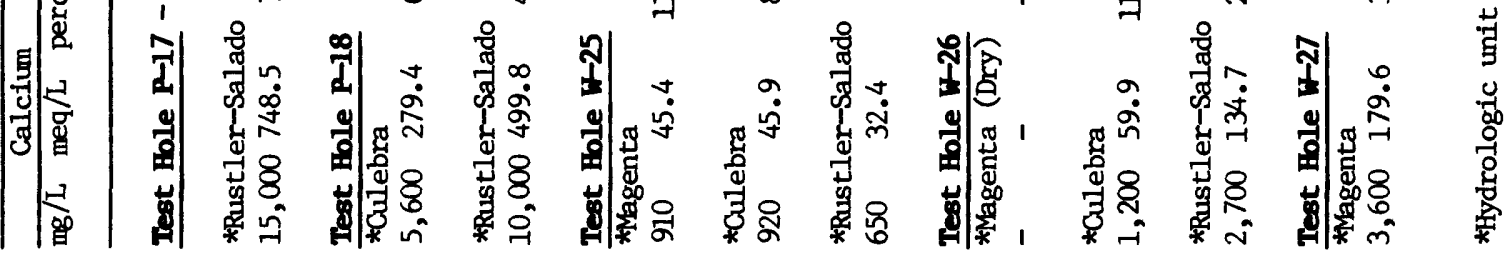




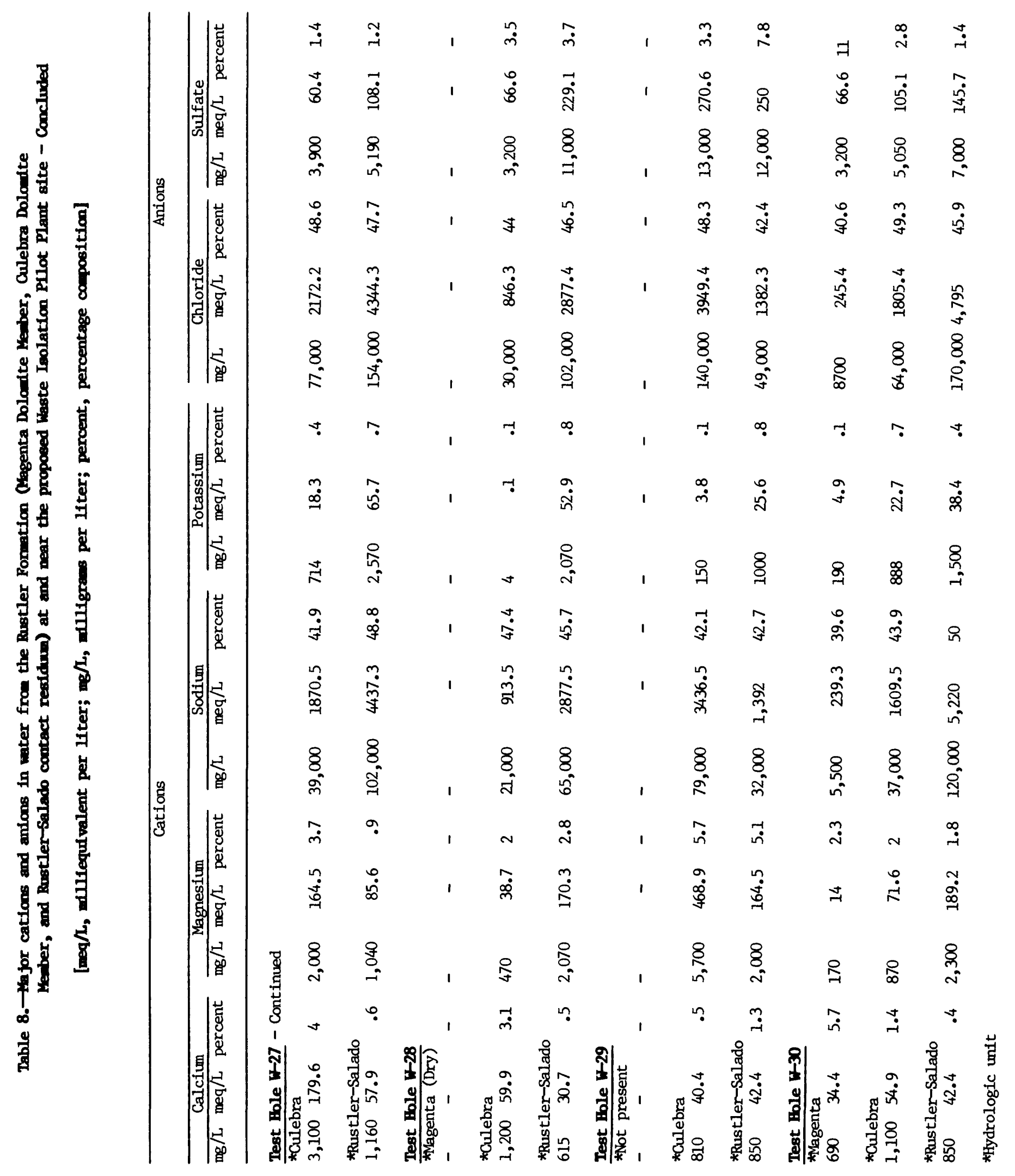


Table 9.-Measured and density-corrected water levels in selected test holes completed in the Culebra Dolonite Member of the Rustler Formation at and near the proposed Waste Isolation Pilot Plant site

\begin{tabular}{|c|c|c|c|c|c|c|}
\hline \multirow[b]{2}{*}{$\begin{array}{l}\text { Test } \\
\text { Hole }\end{array}$} & \multirow{2}{*}{$\begin{array}{l}\text { Altitude of } \\
\text { land surface, } \\
\text { in feet above } \\
\text { sea level }\end{array}$} & \multicolumn{2}{|c|}{ Water level } & \multirow{2}{*}{$\begin{array}{l}\text { Density, } \\
\text { in grams } \\
\text { per cubic } \\
\text { centimeter }\end{array}$} & \multicolumn{2}{|c|}{$\begin{array}{c}\text { Freshwater equivalent } \\
\text { corrected } \\
\text { water level }\end{array}$} \\
\hline & & $\begin{array}{l}\text { Feet below } \\
\text { land surface }\end{array}$ & $\begin{array}{l}\text { feet above } \\
\text { sea level }\end{array}$ & & $\begin{array}{l}\text { Feet below } \\
\text { land surface }\end{array}$ & $\begin{array}{l}\text { feet above } \\
\text { sea level }\end{array}$ \\
\hline $\mathrm{H}-1$ & $3,397.7$ & 382.5 & 3,015 & 1.016 & 378 & 3,020 \\
\hline $\mathrm{H}-2 \mathrm{~B}$ & $3,377.7$ & 348.7 & 3,029 & 1.012 & 345 & 3,033 \\
\hline $\mathrm{H}-3$ & $3,389.5$ & 397.0 & 2,992 & 1.024 & 389 & 3,000 \\
\hline$H-4 B$ & $3,332.9$ & 340.8 & 2,992 & 1.024 & 237 & 2,996 \\
\hline $\mathrm{H}-5 \mathrm{~B}$ & $3,505.9$ & 485.2 & 3,021 & 1.106 & 439 & 3,067 \\
\hline$H-6 B$ & $3,347.6$ & 298.8 & 3,049 & 1.040 & 287 & 3,061 \\
\hline $\mathrm{H}-7 \mathrm{~B}$ & $3,163.6$ & 170.2 & 2,993 & 1.001 & 170 & 2,993 \\
\hline $\mathrm{H}-8 \mathrm{~B}$ & $3,433.8$ & 443.7 & 2,990 & 1.0035 & 443 & 2,991 \\
\hline$H-9 B$ & $3,405.6$ & 425.8 & 2,980 & 1.002 & 426 & 2,980 \\
\hline $\mathrm{H}-10 \mathrm{~B}$ & 3,687 & 697.8 & 2,989 & 1.044 & 667 & 3,020 \\
\hline$P-14$ & $3,359.6$ & 320.1 & 3,040 & 1.018 & 316 & 3,044 \\
\hline$P-15$ & $3,309.5$ & 305.4 & 3,004 & 1.080 & 295 & 3,014 \\
\hline $\mathrm{P}-17$ & $3,335,9$ & 367.3 & 2,967 & 1.082 & 348 & 2,986 \\
\hline $\mathrm{P}-18$ & - & - & - & - & - & - \\
\hline W-25 & $3,212.5$ & 165 & 3,048 & 1.010 & 162 & 3,051 \\
\hline $\mathrm{W}-26$ & $3,151.9$ & 146 & 3,006 & 1.013 & 145 & 3,007 \\
\hline$W-27$ & $3,177.2$ & 105 & 3,072 & 1.094 & 85 & 3,092 \\
\hline$W-28$ & $3,346.8$ & 277 & 3,070 & 1.044 & 270 & 3,077 \\
\hline$W-29$ & 2,977 & 8.2 & 2,969 & 1.178 & 2 & 2,975 \\
\hline$W-30$ & $3,427.5$ & 412 & 3,016 & 1.072 & 395 & 3,033 \\
\hline
\end{tabular}


Table 10.-Heasured and density-corrected water levels in selected test holes completed in the Magenta Dolomite Member of the Rustler Formation at and near the proposed Waste Isolation Pilot Plant site

\begin{tabular}{|c|c|c|c|c|c|c|}
\hline \multirow[b]{2}{*}{$\begin{array}{l}\text { Test } \\
\text { Hole }\end{array}$} & \multirow{2}{*}{$\begin{array}{l}\text { Altitude of } \\
\text { land surface, } \\
\text { in feet above } \\
\text { sea level }\end{array}$} & \multicolumn{2}{|c|}{ Water level } & \multirow{2}{*}{$\begin{array}{l}\text { Density, } \\
\text { in grams } \\
\text { per cubic } \\
\text { centimeter }\end{array}$} & \multicolumn{2}{|c|}{$\begin{array}{c}\text { Freshwater equivalent } \\
\text { corrected } \\
\text { water level }\end{array}$} \\
\hline & & $\begin{array}{l}\text { Feet below } \\
\text { land surface }\end{array}$ & $\begin{array}{l}\text { feet above } \\
\text { sea level }\end{array}$ & & $\begin{array}{l}\text { Feet below } \\
\text { land surface }\end{array}$ & $\begin{array}{l}\text { feet above } \\
\text { sea level }\end{array}$ \\
\hline $\mathrm{H}-1$ & $3,397.7$ & 246.50 & 3,151 & 1.021 & 240 & 3,158 \\
\hline $\mathrm{H}-2 \mathrm{~A}$ & $3,377.9$ & 233.07 & 3,145 & 1.012 & 230 & 3,148 \\
\hline $\mathrm{H}-3$ & $3,389.5$ & 238.30 & 3,151 & 1.010 & 234 & 3,155 \\
\hline$H-4 A$ & $3,332.9$ & 189.3 & 3,144 & 1.017 & 186 & 3,147 \\
\hline $\mathrm{H}-5 \mathrm{~A}$ & $3,506.2$ & 344.5 & 3,162 & 1.008 & 342 & 3,165 \\
\hline$H-6 A$ & $3,347.3$ & 289.8 & 3,056 & 1.007 & 287 & 3,059 \\
\hline $\mathrm{H}-7 \mathrm{~A}$ & - & - & - & - & - & - \\
\hline$H-8 A$ & $3,433.0$ & 405.1 & 3,028 & 1.008 & 404 & 3,029 \\
\hline $\mathrm{H}-9 \mathrm{~A}$ & $3,405.4$ & 282.0 & 3,123 & 1.004 & 281 & 3,124 \\
\hline $\mathrm{H}-10 \mathrm{~A}$ & $3,686.5$ & 586.8 & 3,100 & 1.171 & 469 & 3,218 \\
\hline$W-25$ & $3,212.5$ & 159.0 & 3,054 & 1.010 & 158 & 3,055 \\
\hline$W-27$ & $3,177.2$ & 102.0 & 3,075 & 1.095 & 93 & 3,084 \\
\hline$W-28$ & $3,346.8$ & 202.8 & 3,144 & 1.048 & 198 & 3,149 \\
\hline
\end{tabular}

